\title{
Uma promenade nos trópicos: os barões do café sob as palmeiras-imperiais, entre o Rio de Janeiro e São Paulo
}

Roseli Maria Martins D'Elboux ${ }^{1}$

RESUMO: $\bigcirc$ presente trabalho propõe-se a discutir a transformação da paisagem urbana das cidades vale-paraibanas, a partir do estabelecimento de uma elite ligada à cultura do café nessa região e do surgimento de uma configuração paisagística específica, apoiada na utilização da palmeira-imperial (Roystonea oleracea). Seu recorte cronológico abrange o período entre 1808 e 1911 , enquanto espacialmente seu foco direciona-se para o eixo Rio de Janeiro-São Paulo, com estudo mais aproximado do caso da cidade de Lorena, São Paulo, de modo a cobrir as transformações aí ocorridas desde a chegada do café até o esgotamento dessa cultura. Acompanhando as transformações urbanas do período, surgiram e consolidaram-se exemplos paisagísticos próprios da sociedade do café: ruas arborizadas com renques de palmeiras, a demonstrar a proximidade com a Corte, a sinalizar os novos "modos afrancesados". Utilizaram-se tais configurações com o propósito de qualificar os logradouros públicos, a fim de equipará-los aos novos edifícios que substituíam aqueles da tradição colonial. $\bigcirc$ texto desenvolve-se em três momentos principais: a introdução da palmeira-imperial no Rio de Janeiro, sua vinculação à idéia de nobreza e classe, e conseqüente aproximação com a arquitetura neoclássica trazida pela Missão Francesa de 1816; a difusão de sua utilização como recurso paisagístico qualificador dos espaços públicos desde a Corte até a capital paulista, principalmente pelo baronato do Segundo Império; e, finalmente, a possibilidade de sua introdução nos espaços públicos paulistanos ter sido viabilizada por um lorenense, vinculado à elite cafeeira, embora já sob a República.

PALAVRAS-ChAVE: Século XIX. Vale do Paraíba. Lorena. Palmeira-imperial. Patrimônio paisagístico. Paisagem urbana.

ABSTRACT: This paper proposes to discuss the transformation of urban landscapes in the Paraiba River Valley as members of the coffee elite emerged in this area and a specific landscape configuration was projected there based on the use of imperial palms (Roystonea oleracea). Chronologically speaking, the paper covers a period from 1808 to 1911 ; with regard to
1. Mestre em História e Fundamentos da Arquitetura e do Urbanismo, FAU-USP, docente do curso de Arquitetura e Urbanismo do Centro Universitário FIAM-FAAM, São Paulo. E-mail: <rdelboux @usp.br>.

A autora agradece ao $\mathrm{Mu}-$ seu Paulista da Universidade de São Paulo, ao Museu Histórico Nacional, Biblioteca Municipal Mario de Andrade, Instituto de Pesquisas Jardim Botânico do Rio de Janeiro, Editora Solaris e Ércio Molinari pela cessão gratuita dos direitos de reprodução de algumas das imagens utilizadas neste artigo, bem como a José Francisco Vidal Martins, pelo auxílio na procura de documentos em Lorena. 
2. O resultado da pesquisa encontra-se em nossa dissertação de mestrado - Manifestações neoclás sicas no Vale do Paraíba: Lorena e as palmeiras-imperiais -, apresentada, em 2005, à Faculdade de Ar quitetura e Urbanismo da Universidade de São Paulo. space, it focuses on the stretch between Rio de Janeiro and São Paulo, with a closer look at the case of the city of Lorena (SP), so as to encompass all the changes that took place in this region from the introduction to the decline of coffee growing as an economic activity. The urban changes during this period were accompanied by the advent and consolidation of landscapes typical of the society of coffee growers: streets lined with palm trees, a token of their close connections with the royal court, a display of their adherence to "Frenchified customs". Such configurations were used to characterize public areas and raise them to the same status as the new buildings that gradually replaced those built in colonial style. The paper is structured around three key moments, namely: the introduction of imperial palms in Rio de Janeiro and their association with the idea of nobility and rank, and consequently with neoclassical architecture, which was brought to the colony by the 1816 French Mission; the dissemination of the use of imperial palms as a landscaping resource typical of public spaces from the royal court to the capital of São Paulo, particularly by the coffee barons during the second period of monarchic rule; and, finally, the hypothesis that the use of imperial palms to embellish public areas in São Paulo may have been introduced by a Lorena citizen associated with the coffee elite, albeit later, when Brazil was already a republic.

KEYWORDS: $19^{\text {th }}$ century. Paraíba River Valley. Lorena. Imperial palm. Landscape heritage. Urban landscape.

presente artigo é fruto de uma pesquisa de maior âmbito cujo objetivo era a identificação das transformações ocorridas na paisagem urbana lorenense no período 1830-1890, como resultado da aplicação de riquezas geradas a partir do cultivo do café no Vale do Paraíba, colocando-se como premissa que a produção do ambiente é, também, a produção da identidade de uma sociedade?

Faz-se necessário esclarecer que o trabalho aqui apresentado parte de algumas verificações da pesquisa original e avança um pouco além, no que se refere à questão da difusão e uso das palmeiras-imperiais em São Paulo. Deste modo, o arco de tempo estudado amplia-se, recuando até 1808 lano da chegada da Corte portuguesa ao Rio de Janeiro) e avançando até 1911 (ano da inauguração o Teatro Municipal de São Paulo, já sob a Primeira República).

Para que não haja confusão a respeito do principal objeto deste trabalho, é preciso caracterizá-lo devidamente. A espécie em questão é a palmeira-imperial (Roystonea oleracea (N. J. Jacquin) O. F. Cook), muito utilizada no século XIX, e mesmo atualmente, nos logradouros públicos das cidades brasileiras, a qual

caracteriza-se por possuir um tronco simples, colunar, de delineamento uniforme, esbranquiçado, liso, sem dilatações, com palmito volumoso exposto no topo, de 15 a $30 \mathrm{~m}$ de altura e com cerca de $62 \mathrm{~cm}$ de diâmetro em média. [...] Originária das Antilhas e norte da Venezuela [...] demanda locais expostos, espaçosos e a pleno sol para bom desenvolvimento (LORENZI et al., 1996, p. 276).

Para compreender como a idéia de "clássico" é agregada a essa espécie - e como ela passa a desempenhar o papel de elemento paisagístico representativo daquele momento, um signo do próprio Império -, resgatou-se a 
história de sua chegada ao Rio de Janeiro, a partir do esforço de aclimatação de espécies exóticas para uma produção rentável, pela necessidade de geração de renda para o sustento da Corte. Àquela época, a questão da exploração de essências nativas ou exóticas era uma possibilidade de reverter o quadro econômico que se instalara em Portugal, no âmbito das colônias portuguesas, tanto no Brasil como em África. Além disso, Portugal visava também à exclusividade do cultivo dessas espécies, numa ferrenha disputa com França, Inglaterra e Holanda.

Surgem, então, algumas iniciativas, como a criação dos hortos botânicos, sendo o mais significativo deles o Jardim Botânico do Rio de Janeiro. Nesse quadro, são realizadas algumas experiências para o cultivo do café, e a introdução da palmeira-imperial dá-se pouco tempo depois da chegada da rubiácea.

Utilizadas inicialmente na cidade do Rio de Janeiro, difundem-se rapidamente pela província fluminense e, no rastro da cultura cafeeira, acabam alcançando a província paulista em meados do novecentos, sendo empregadas com sucesso nas reformas urbanas realizadas na cidade de São Paulo nas primeiras décadas do século XX.

Esse percurso - um entre tantos, se considerar-se que exemplares de Roystonea oleracea podem ser encontrados em outras regiões do país - é múltiplo, e nosso propósito aqui é mostrar justamente essa multiplicidade, que vai além da mera difusão geográfica do uso de uma determinada espécie vegetal, mas abrange questões sociais, políticas e culturais, porque, no processo de transferência da espécie desde o Rio de Janeiro até São Paulo, importa, também, a sua vinculação aos diferentes regimes políticos que se sucederam desde 1808; e o significado de sua presença nos espaços públicos onde é utilizada.

Se a palmeira é a espécie preferida de D. João VI, em seguida ficará estreitamente vinculada à imagem do Segundo Império e, posteriormente, à Primeira República. $\bigcirc$ fator que confere unidade a esses diferentes momentos, em termos sociais, é a elite rural, que apóia tais regimes segundo suas próprias conveniências e foi enriquecendo pelos ótimos resultados financeiros obtidos da grande monocultura cafeeira. Assim, tal percurso circunscreve-se às cidades do Rio de Janeiro, São Paulo e Lorena, no Vale do Paraíba paulista, importante ponto de inflexão de rotas e caminhos nos períodos colonial e imperial.

Lorena foi, durante certo tempo, a última fronteira do sertão na direção "norte" 3 da Capitania de São Paulo, nascendo o seu núcleo original justamente no ponto de travessia do Rio Paraíba em direção ao sertão das "minas gerais". Descoberto o ouro, passa a ser ainda, em função da transposição do Paraíba, ponto de descanso dos tropeiros que faziam o fluxo aurífero. Torna-se entroncamento de caminhos, já que, desde Lorena, as tropas vindas de Minas podiam dirigir-se a São Paulo; ou, após vencer a serra de Quebra-Cangalha e descer a serra do Mar, alcançar os portos de Parati, Mambucaba ou Ubatuba e, então, seguir por mar para o Rio de Janeiro.

Aliás, é devido à parada para a travessia do rio que foi erguida a capela da Piedade de Guaypacaré, ermida fundadora da cidade. Dos caminhos tropeiros em direção à Mantiqueira, ao Rio de Janeiro ou à vila de Guaratinguetá,
3. O correto seria direção leste, mas utilizamos aqui a designação usual à época. 
definiram-se os principais eixos da cidade, ainda hoje reconhecíveis no traçado urbano lorenense e de onde evoluíram os três espaços públicos que são examinados neste trabalho.

No final do século XVIII, é de Lorena que parte o Caminho Novo da Piedade, a estrada que fará a ligação terrestre entre São Paulo e a Corte. Essa situação privilegiada vai dar espaço para outras possibilidades, ou seja, na geopolítica da colônia, torna-se um centro importante de articulação entre três províncias - São Paulo, Rio de Janeiro e Minas Gerais.

Dentro do conjunto do patrimônio urbano vale-paraibano, Lorena destaca-se devido à existência, na cidade, de algumas obras de Ramos de Azevedo, o mais famoso arquiteto paulista do período: a lgreja Matriz de Nossa Senhora da Piedade e algumas intervenções ou reformas que the são atribuidas, como a do Solar dos Azevedo llocalizado na mesma praça onde se ergue a Matriz), a Igreja do Rosário, e a Capela de São Miguel das Almas, mausoléu da família Moreira Lima no cemitério municipal.

Além do exposto acima, já suficiente para justificar a sua escolha como estudo de caso, Lorena comparece neste trabalho porque, no desenrolar da pesquisa, alguns fatos mostraram-se reveladores, no sentido de que a cidade talvez tenha constituído importante ligação entre o Rio de Janeiro e São Paulo quanto à difusão do uso das palmeiras-imperiais na capital paulista.

Do relacionamento entre a burguesia surgida em função da cultura cafeeira e o núcleo inicial da cidade, várias ações transformadoras vão tomar corpo, notadamente no último quartel do século, revelando a tensão entre o caráter colonial do sítio e o caráter quase cosmopolita dos cidadãos de então, a reclamar "melhorias" às autoridades.

No entanto, se na maioria das vezes a configuração inicial de tais espaços é o da tradição colonial paulista (no sentido de que não foram concebidos por um projeto preciso, sendo fruto, em grande parte, das rotas e caminhos para o sertão), posteriormente, principalmente a partir de meados do século XIX, esses espaços serão a base para a nova concepção de cidade importada da corte e, por extensão, da Europa, onde, nesse mesmo período, ocorre a discussão sobre a validade do uso das formas tradicionais em contextos cada vez mais industrializados. Na Inglaterra, a expressão local que mais contribui para o período é o surgimento do chamado jardim paisagista, que, transposto à França, origina $\mathrm{o}$ jardin anglais.

No Rio de Janeiro, sob a influência da chegada da Corte e da Missão Francesa, a atuação de Grandjean de Montigny, do ponto de vista das intervenções urbanas, abre caminho para os trabalhos de Glaziou, na segunda metade do século.

A contribuição francesa foi significativa, apesar da pequena produção, justamente porque nos trouxe uma maneira diversa de se pensar a arquitetura, não importando se boa, má, ou muito européia e pouco comprometida com as condicionantes locais. Conjuntamente com a questão do gosto, vieram contribuições no que se refere aos processos do fazer arquitetônico, questões 
de sistematização de projeto e do canteiro de obras, e também outras, referentes ao entendimento da questão urbana, como por exemplo,

a remodelação do antigo largo do Valongo, depois praça Municipal, de que resultou imponente logradouro; a abertura da rua e praça fronteira ao edifício da antiga Academia; o alargamento e retificação da rua Estreita de São Joaquim, ligando, assim, o cais dos Mineiros o 'aterrado', ou 'caminho das lanternas' (o atual Mangue); o plano de urbanização do centro da cidade e sua conseqüente ligação com a parte suburbana, maravilhoso estudo, prevendo o desenvolvimento natural da Capital do Império; e o projeto referente às ruas e praças que deviam rodear o novo edifício do Senado, realçando-the o aspecto.

[Grandjean de Montigny] pugnou pela abolição das ruas estreitas; arborização das vias e praças públicas, recuo sistemático da edificação nas ruas cujo alinhamento devia ser ratificado [sic]; e ampliação das vias de comunicação e das praças da urbe carioca. Como arquiteto paisagista - que o era exímio - deixou um projeto, composição monumental, para - Campo de Santana, a atual praça da República, obra vasta e poucos anos após a sua morte realizada por Augusto Glaziou (TAUNAY, 1983, p. 302).

No rastro da mudança da base produtiva, ocorreram mudanças nas relações sociais e, conseqüentemente, na vida e aparência das cidades do Vale do Paraíba, especialmente em Lorena. O baronato local agiu no sentido de melhorar não só as condições de vida dentro de suas casas, como também de transformar a vida da cidade em geral, pelo financiamento de melhoramentos, quer fosse em termos de infra-estrutura, quer em termos de ornamentação. Para tanto, a transformação dos espaços públicos passava pela negação do modelo colonial, das origens. Era preciso estar mais próximo da Corte e dos hábitos cortesãos, intenção refletida pelo tratamento dispensado às praças da Imperatriz, da Matriz e à rua Direita latuais Dr. Arnolfo de Azevedo, praça Baronesa de Santa Eulália e rua Viscondessa de Castro Lima, mais popularmente conhecida como rua das Palmeiras), que ostentavam renques de palmeiras-imperiais, a exemplo dos existentes no Jardim Botânico do Rio de Janeiro e em outros logradouros da Corte.

A identidade da cidade vai moldar-se a partir da adoção dessa linguagem - solene e transbordante de monumentalidade - para os espaços públicos, transformando-os em testemunhos de uma época de riqueza e ostentação; e, atualmente, nos cartões postais de Lorena. Não à toa, durante boa parte do século XX, a cidade adota como lema a frase: Terra das palmeirasimperiais (Figura 1).

Ao fim, abordamos a introdução da palmeira-imperial na capital paulista. Embora de maneira superficial, julgamos de grande interesse apresentálo aqui, porque se refere à possibilidade, ainda por ser verificada - e esse constitui-se o nosso esforço atual - de que um lorenense tenha sido o introdutor do uso da espécie em São Paulo, no final do século XIX, concomitantemente à sua introdução em Lorena. Assim, fica claro que o tema, bastante amplo, não se esgota aqui, mas abre um leque de possibilidades de pesquisas futuras. 


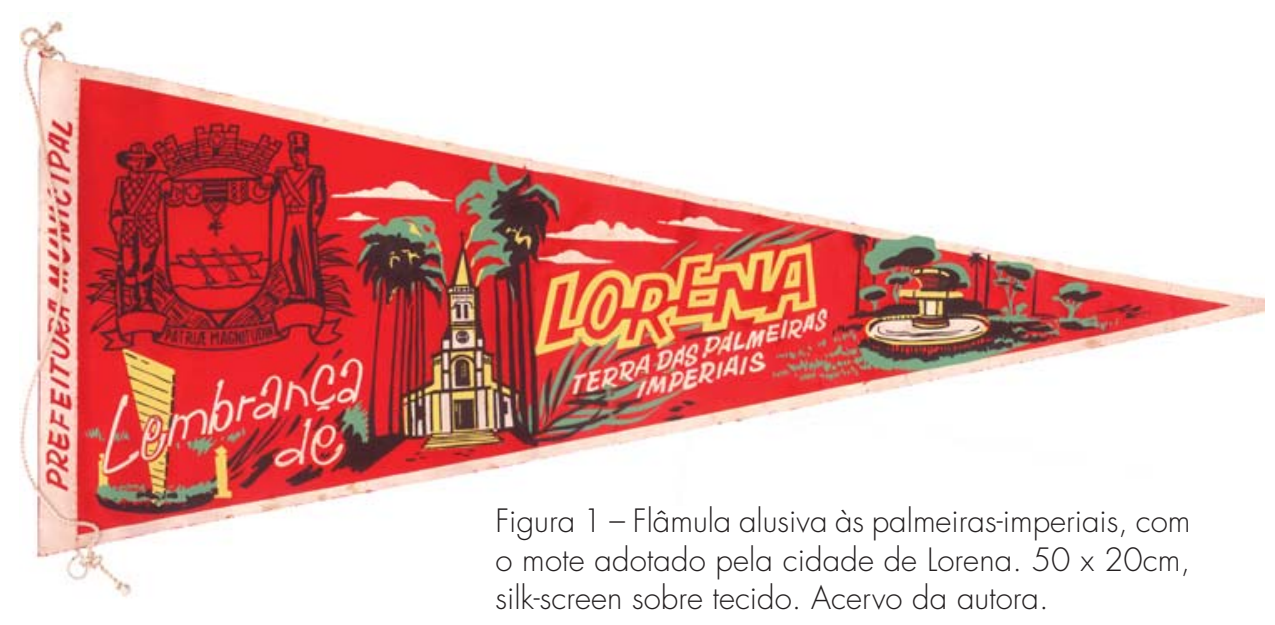

A Palma mater: introdução no Brasil e vinculação à idéia de nobreza e poder

Na tentativa de compreender como a espécie Roystonea oleracea passa a desempenhar um papel preponderante nas composições paisagísticas do período e da região estudados - e de como a sua imagem acaba associada ao repertório das formas clássicas e ao fausto trazido pelo ciclo cafeeiro -, buscou-se resgatar a sua história: como chegou ao Brasil e como passa a ser tão cara à casa Real, desde D. João VI até seu neto D. Pedro II. E, findo o Segundo Império, como continua a ser utilizada como elemento qualificador dos espaços públicos durante boa parte do período republicano.

Warren Dean (2001), em A botânica e a políitica imperial: introdução e adaptação de plantas no Brasil colonial e imperial, faz um interessante relato sobre a aclimatação de espécies exóticas no Brasil. Embora o seu texto tenha sido escrito visando a contribuir com a questão ecológica contemporânea, aborda também alguns aspectos históricos interessantes para a presente pesquisa, principalmente quando relata como se deu a curiosa introdução da palmeiraimperial entre nós.

Além das conseqüências econômicas, houve uma conseqüência ecológica, com a mudança de habitat de várias espécies; e, com sua adaptação, uma sensível transformação na paisagem das colônias. Segundo o autor, esse "processo de reorganização da paisagem brasileira" gerou resultados que "influenciaram decisivamente na posição que a colônia e, mais tarde, o Império independente conseguiram manter na economia mundial" (Dean, 2001). Referese aqui, evidentemente, ao poder transformador das monoculturas que foram sucessivamente instaladas em nosso território - cana, algodão, café. Mas, mesmo em uma outra escala, a introdução de espécies exóticas promoveu alterações nas características paisagísticas locais. Este é o caso da palmeiraimperial e do processo de difusão de seu plantio. 
A introdução sistematizada de tais espécies remonta ao início do século XVIII, época marcada

pela emergência de novos e poderosos instrumentos de intercâmbio de espécies tropicais: - jardim botânico colonial e o herbário [na metrópole]. O herbário permitiu o estudo comparativo na Europa de espécies secas enviadas de cada canto do mundo tropical; e os jardins botânicos, formados em redes centradas nas respectivas metrópolis [sic], facilitaram o intercâmbio entre colônias tropicais. [...] Além disso, a investigação foi assim colocada numa base científica, com maior potencialidade de acumulação e sistematização de informações (DEAN, 200 1, p. 7).

De acordo com os interesses mercantilistas portugueses, nessa época são instituídos jardins e hortos botânicos no Rio de Janeiro (1772), em São Paulo (1779), em Belém do Pará (1796) e, após 1802, os hortos de Salvador e de Ouro Preto. Ao final do século XVIII, várias iniciativas oficiais foram tomadas, a fim de que se transferisse e aclimatasse o maior número possível de espécies; foram também organizadas importantes obras botânicas, como a Florae fluminensis, do padre José Mariano Conceição Veloso.

Mas é somente a partir da chegada da Corte portuguesa ao Rio de Janeiro que se empreendeu um verdadeiro "programa de investigação" sobre o assunto, resultando, de imediato, no estabelecimento de um jardim de aclimatação ao lado da lagoa Rodrigo de Freitas, já em 1808, através do Decreto de 13 de junho desse mesmo ano (DEAN, 2001 , p. 10). Em Edital da Junta do Comércio, datado de 27 de julho de 1809, foram instituídos prêmios, medalhas e, inclusive, isenção de impostos e dispensa do serviço militar para quem remetesse sementes e mudas de novas espécies da Índia para essas recém-implantadas instituições (DEAN, 200 1; SARTHOU, 1965)

Em 1809, Luiz d'Abreu Vieira e Silva, chefe de divisão da marinha portuguesa, chegou ao Rio de Janeiro após ter conseguido permissão para deixar a ilha de França (atual ilha Maurício), para onde havia sido levado, após ter sido capturado devido ao naufrágio de sua embarcação, a fragata Princesa do Brasil. Fretado o veleiro La Ville d'Autun, duzentos portugueses embarcaram com destino ao Brasil.

Antes porém, haviam conseguido, de modo ilegal, encher vinte caixotes de sementes de plantas exóticas do Jardin Le Pamplemousse, horto botânico fundado pelos franceses na itha. Tais sementes eram de canela, noz-moscada, fruta-pão, cânfora, toranja, sagüeiro, cajá-manga, lechia, abacate, cravo-daíndia e manga, fruta que já fora introduzida há mais de um século e estava perfeitamente aclimatada por aqui (DEAN, 1996; SARTHOU, 1965).

Além das espécies frutíferas, Vieira e Silva "presenteou o rei com Roystonea oleracea, uma palmeira nobre, de altura imponente, que logo passou a enfeitar todos os jardins aristocráticos no Rio de Janeiro e ainda hoje forma uma impressionante aléia na avenida central do próprio Jardim Botânico" (DEAN, 1996, p. 143), tornando-se o seu "ornamento mais distinto" (DEAN, 200 1, p. 13). Ocorrem nessa época, também no mesmo Jardim Botânico do Rio de Janeiro, 
as primeiras experiências com o cultivo do café; assim, ambas as espécies foram aqui introduzidas quase simultaneamente.

Convém observar, no entanto, que a espécie Roystonea oleracea é originária das Antilhas, tendo sido aclimatada pelos franceses no jardim botânico La Gabrielle, instalado na Guiana Francesa, e depois transferida para o Jardin de Pamplemousse.

Segundo Sarthou (1965), a semente dessa palmeira (Roystonea oleracea (N. J. Jacquin) O. F. Cook), foi plantada pelo próprio príncipe regente e, a partir de então, ficou conhecida popularmente como palmeira-real ou palmeira-imperial. Recebeu o nome de Palma mater porque todas as palmeiras existentes no Brasil são suas descendentes (Figuras 2 a 5):

São suas filhas ou netas, a [sic] 128 palmeiras que compõem a alameda principal em frente ao portão de entrada [do Jardim Botânico].

Têm o mesmo parentesco as 142 palmeiras que compõem a alea paralela à rua Jardim Botânico.

São suas filhas, netas ou bisnetas, as palmeiras do Mangue e da rua Paisandú.
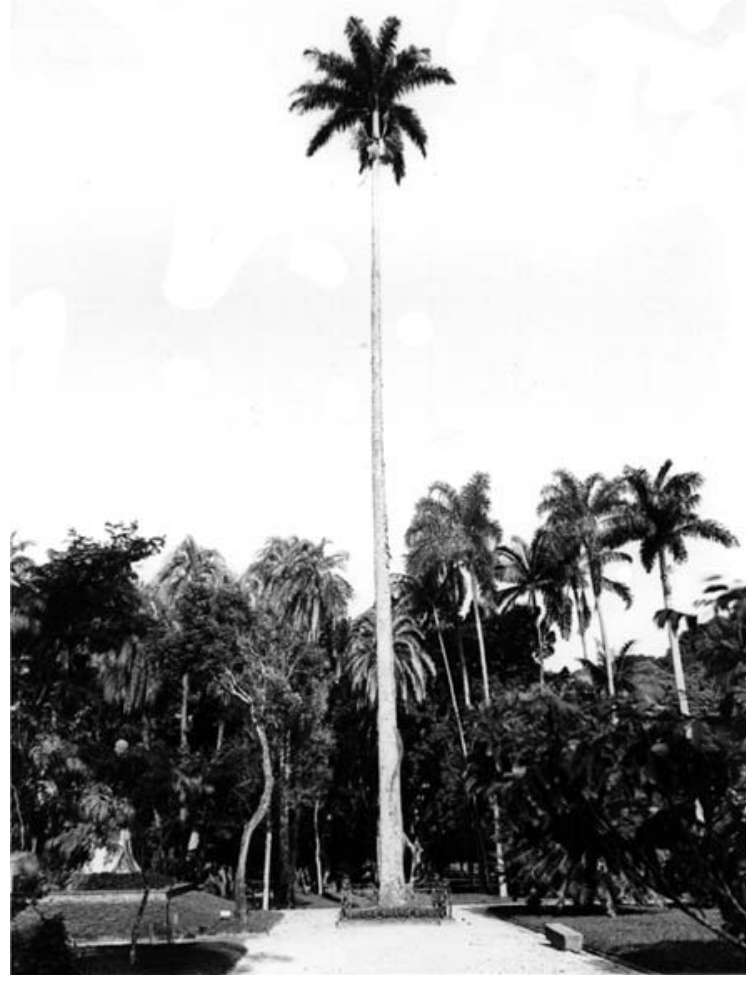

Figura 2 - A Palma mater no Jardim Botânico do Rio de Janeiro, c. 1920, Rio de Janeiro. Fotografia. Acervo do Instituto de Pesquisas Jardim Botânico do Rio de Janeiro, Rio de Janeiro.

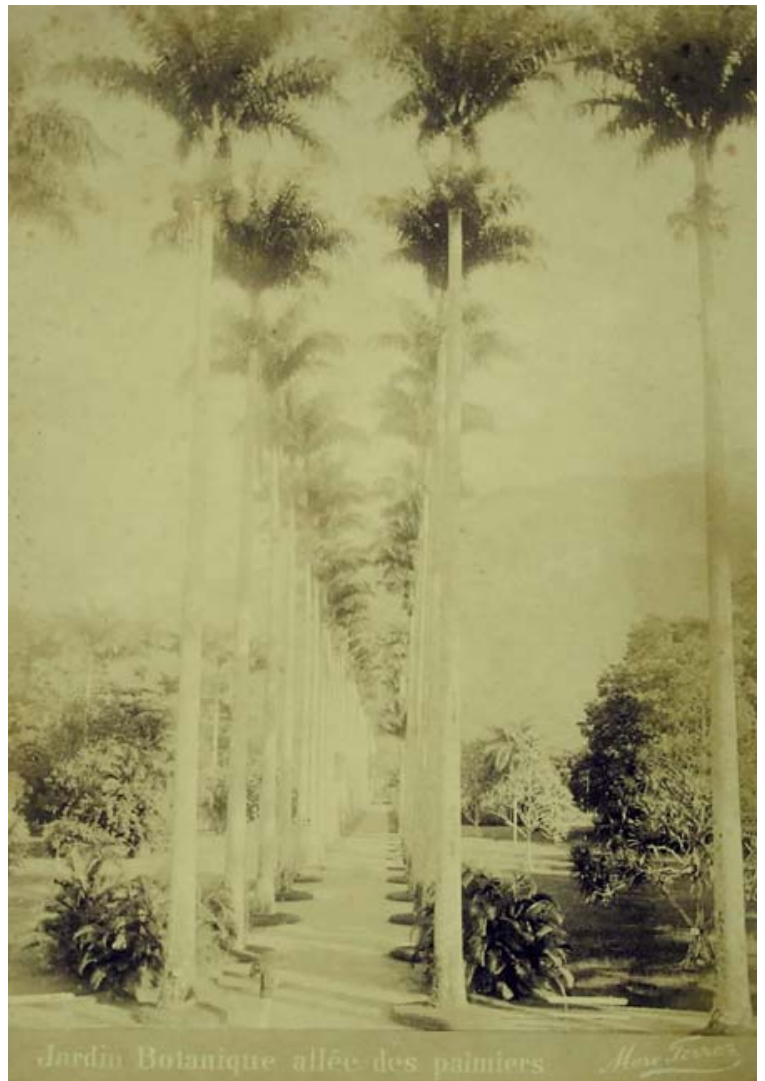

Figura 3 - Marc Ferrez, Jardin Botanique allée des palmiers, c. 1890, Rio de Janeiro. $22 \times 16 \mathrm{~cm}$. Acervo da Biblioteca Municipal Mário de Andrade, São Paulo. 


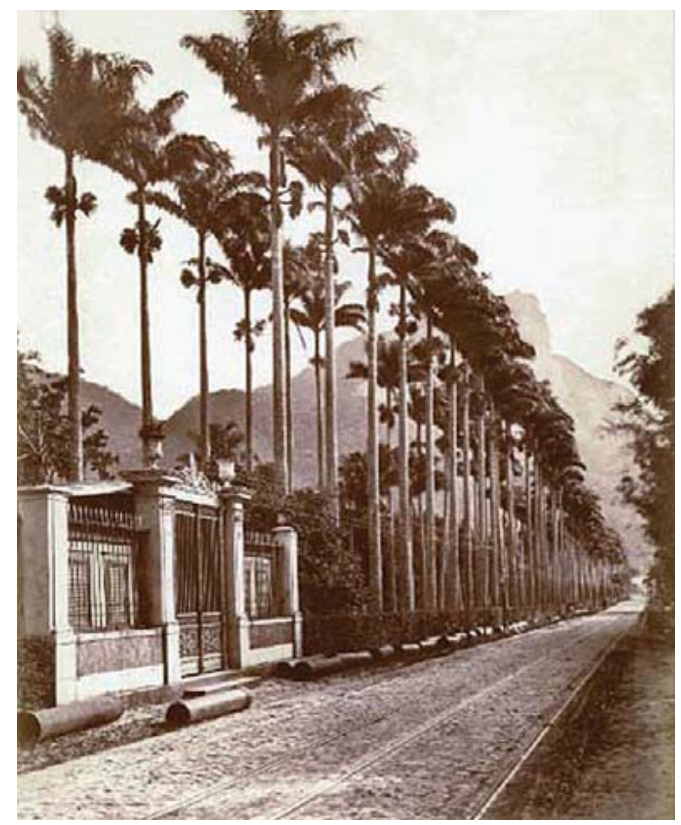

Figura 4 - Juan Gutierrez, Entrada do Jardim Botânico, c. 1893, Rio de Janeiro. $20 \times 25 \mathrm{~cm}$, papel albuminado. Acervo do Museu Histórico Nacional, Rio de Janeiro, disponível em: <http://www. museuhistoriconacional.com.br>.

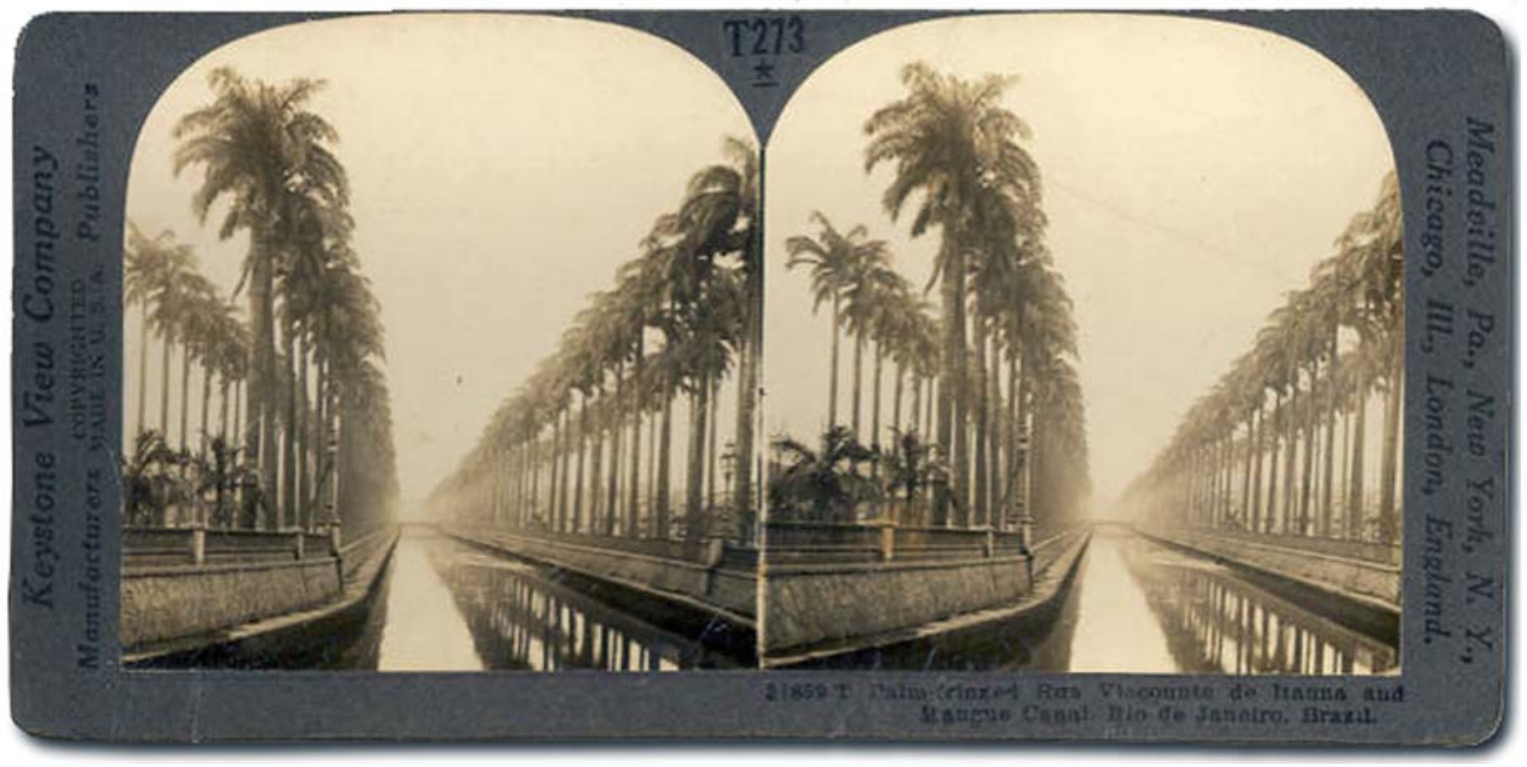

Figura 5 - Palmeiras bordejando a Rua Visconde de Itauna e o Canal do Mangue, Rio de Janeiro, Brasil, início do séc. XX. Estereoscopia. Acervo particular, São Paulo. 
4. Seu tronco encontra-se exposto no Museu Botânico. Jardim Botânico do Rio de Janeiro.
São finalmente suas descendentes diretas tôdas, absolutamente tôdas as palmeiras da mesma espécie existentes no Rio de Janeiro e em todo o Brasil (SARTHOU, 1965, p. 58).

A Palma mater existiu até 1972, quando foi atingida por um raio. Durou portanto, 163 anos, alcançando 38,70 metros de altura ${ }^{4}$. Outro exemplar foi plantado em seu lugar e denominado Palma filia (IPJBRJ, 2004).

Crescendo e desenvolvendo-se, passou a despertar a atenção pela sua exuberância e porte. Segundo uma tradição oral, a partir do momento em que a palmeira começa a frutificar, o então diretor do Jardim Botânico, Serpa Brandão, com a intenção de preservar o monopólio da instituição sobre a espécie, determinou que se queimassem anualmente todas as suas sementes (IPJBRJ, 2004; SARTHOU, 1965). A informação de que um quilo contém cerca de 1954 frutos - e 4374 sementes, que levam em média 70 dias para germinar (LORENZI et al., 1996, p. 276) - dá-nos a dimensão das preocupações de Serpa Brandão, se considerarmos que cada frutificação deve alcançar facilmente cinco quilos.

Entretanto, segundo essa mesma tradição oral, conta-se que "os escravos que trabalhavam no Jardim levantavam-se durante a noite e subindo à arvore colhiam as sementes que vendiam a 100 réis cada uma" (IPJBRJ, 2004; SARTHOU, 1965); e esta seria a razão da sua ampla e rápida difusão, tornandose mais conhecida até do que palmeiras da flora nativa, apesar dos esforços do administrador do Jardim Botânico.

Uma outra versão informal (e também de tradição oral) dá conta de que, para a sua difusão, além das sementes vendidas clandestinamente pelos escravos, colaborou o hábito do imperador D. Pedro Il de oferecê-las aos súditos mais fiéis como símbolo de lealdade à coroa. Disso resultaria a sua presença nos jardins dos solares e fazendas da nobreza do Império brasileiro.

Desse modo, depois de alguns anos, a espécie vincula-se definitivamente à imagem do poder monárquico, à idéia de nobreza, distinção e classe. Essa associação é tão forte, que mesmo textos de caráter técnico, como manuais de botânica e horticultura, incluem tais atributos em suas descrições da espécie, como podemos observar em Lorenzi (1996, p. 276) e Graf (1986, p. 801 e 1081), que utilizam, respectivamente, os termos "imponente", "símbolo aristrocrático" e "majestic". Atributos esses também presentes na arquitetura neoclássica, e, no caso fluminense, particularmente, naquela trazida e ensinada por Grandjean de Montigny, arquiteto integrante da Missão Artística Francesa de 1816

No Jardim Botânico do Rio de Janeiro, as palmeiras-imperiais foram plantadas em aléias, despertando a curiosidade e o encantamento dos seus visitantes que, como antes afirmamos, não se furtavam a compará-las com elementos da arquitetura clássica. Tal foi o caso de Charles Ribeyrolles (1980, p. 193), que registra sua admiração pelo efeito que the causou o encontro, em 1858, com as famosas palmeiras:

Nesse jardim, pobre em espécies, deficiente quanto à ciência, se ostenta dupla colunata como jamais tiveram palácios e templos. É uma aldeia [sic] de palmeiras em dois renques. Regularmente espaçadas, cheias em baixo, de fuste esbelto, abrem-se em capitel numa coroa de flores. Nunca cabeças de fidalgos ostentaram tão belas plumagens. Lá estão elas 
de guarda, noite e dia, imóveis como mármores. Aos raios do luar, à vista desses alvos espectros, dir-se-ia uma enfiada de colunas tebanas. Esse primeiro aspecto da grande alameda, ao mesmo tempo, encanta e impressiona. Não se quer ver nem procurar mais nada. Faz-se a corte às palmeiras.

A senhora Agassiz, acompanhando o marido em viagem ao Brasil, também se impressionou com as palmeiras do Jardim Botânico. Está inclusa em Viagem ao Brasil, o livro que narra as impressões de viagem do casal, uma gravura da mesma aléia, feita a partir de uma fotografia de Augusto Stahl, tirada por volta de $1865^{5}$ (Figura 6). Agassiz (1975) também as compara a colunas clássicas, quando comenta sobre a beleza das palmeiras:

O que empresta, porém, a esse jardim uma fisionomia talvez única no mundo é a sua longa e feérica aléa de palmeiras, cujas árvores têm mais de oitenta pés de altura [24,50 m]. [...] Retos, rígidos, polidos como fustes de granito gigantescos, semelham, no deslumbramento duma visão, a colunada sem fim de um templo do velho Egito.

Assim ocorreu a sua disseminação, associada à idéia da nobreza da linguagem neoclássica. Essa associação foi cultuada e preservada, sempre e

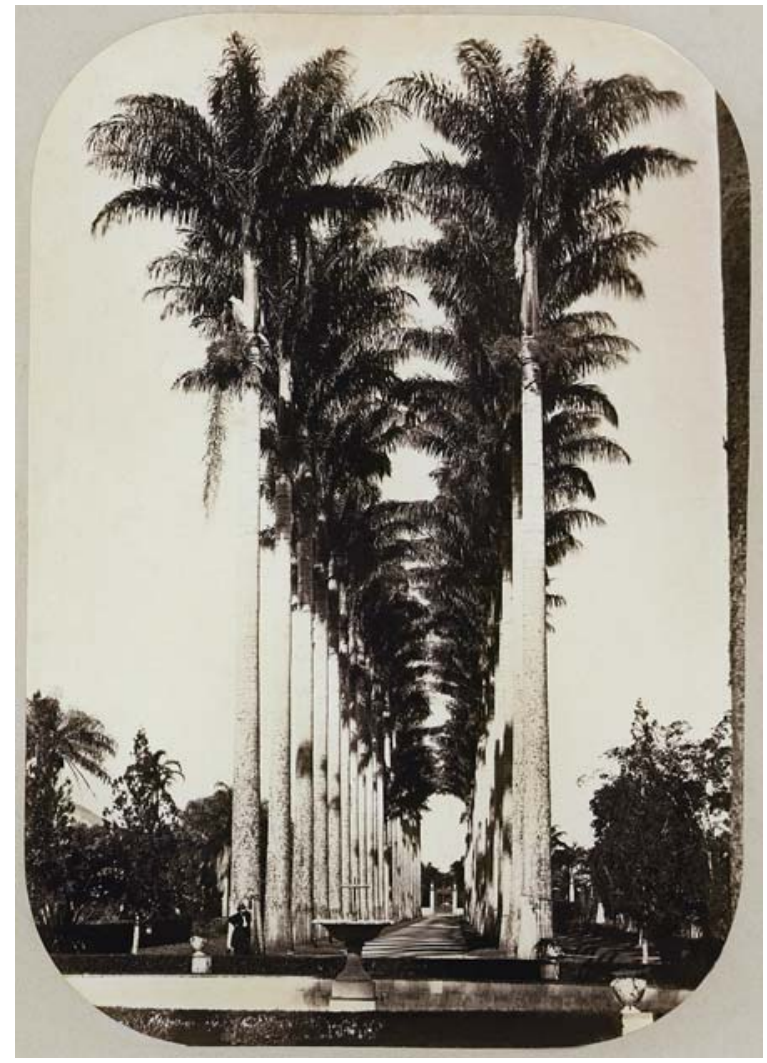

Figura 6 - Augusto Stahl, Aléia de palmeiras no Jardim Botânico, c. 1865, Rio de Janeiro, RJ. 25,4 × 17,8cm, albúmen. Acervo do Instituto Moreira Salles, Rio de Janeiro. 
6. Cf. Coleção $O$ Rio de Janeiro de Juan Gutier rez, Museu Histórico Nacional, Rio de Janeiro. na medida do possível, pelas gerações dos descendentes do D. João Vl; e, aqui, entenda-se descendência tanto genealógica quanto do ponto de vista da prestígio e destaque social. Ao redor da Palma mater foram plantadas outras palmeiras: pelo príncipe D. Pedro de Orléans e Bragança, tataraneto de D. João VI, em 1937; pelo presidente Getúlio Vargas, em 1938; e até pelo presidente português Craveiro Lopes, em 1957 (SARTHOU, 1965).

A difusão das palmeiras pela cidade do Rio de Janeiro

Ao que parece, todos os esforços das sucessivas administrações do Jardim Botânico foram em vão. A despeito do propalado cuidado com as sementes, o uso das palmeiras-imperiais foi se alastrando pela cidade do Rio de Janeiro e arredores. A partir de registros fotográficos realizados desde meados do século XIX, é possível observar na paisagem carioca a presença constante de exemplares da espécie.

Como ou quando esse processo se inicia, não se conseguiu estabelecer com certeza, mas o fato é que, em fins daquele século, muitos dos principais espaços públicos cariocas abrigavam conjuntos de palmeiras-imperiais. Tais conjuntos podem ser observados em imagens produzidas por Juan Gutierrez, fotógrafo espanhol que atuou no Rio nas décadas de 1880 e $1890^{\circ}$. Grupos de Roystonea oleracea estão presentes em panoramas dos bairros do Catete, Flamengo, Urca, Glória, Lapa, Laranjeiras, e em registros dos jardins do Paço de São Cristóvão (Figura 7), da Casa da Moeda (Figura 8), do Ministério da Agricultura e do palácio do barão de ltamaraty (Figura 9), produzidos entre 1893 e 1894.

Há imagens que apresentam aspectos da praia de Botafogo (Figura 10), por exemplo, em que se observam vários conjuntos, a maioria dispostos

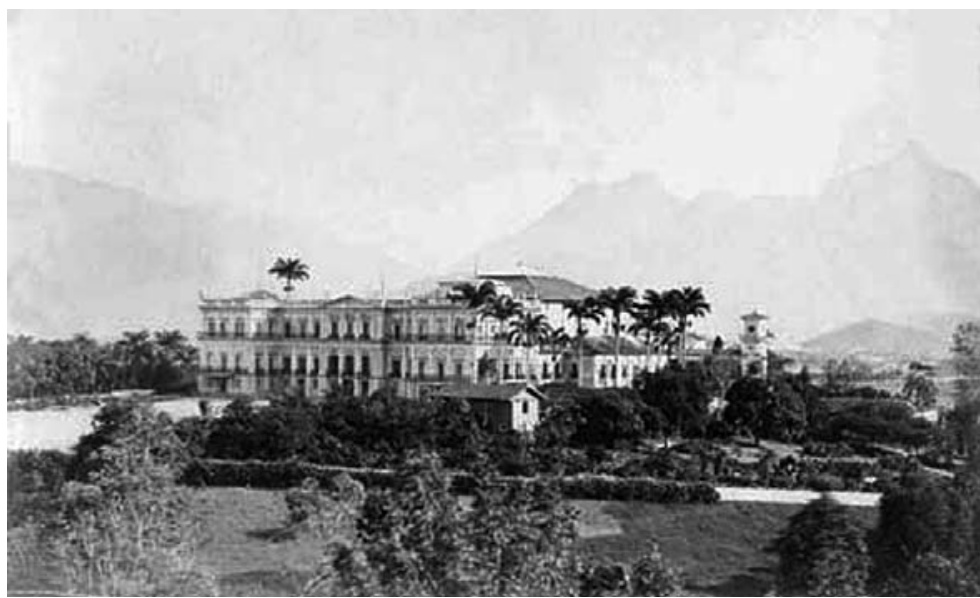

Figura 7 - Juan Gutierrez, Paço de São Cristóvão, c. 1893, Rio de Janeiro. $20 \times 25 \mathrm{~cm}$, papel albuminado. Acervo do Museu Histórico Nacional, Rio de Janeiro, disponível em: <http://www.museuhistoriconacional.com.br>. 


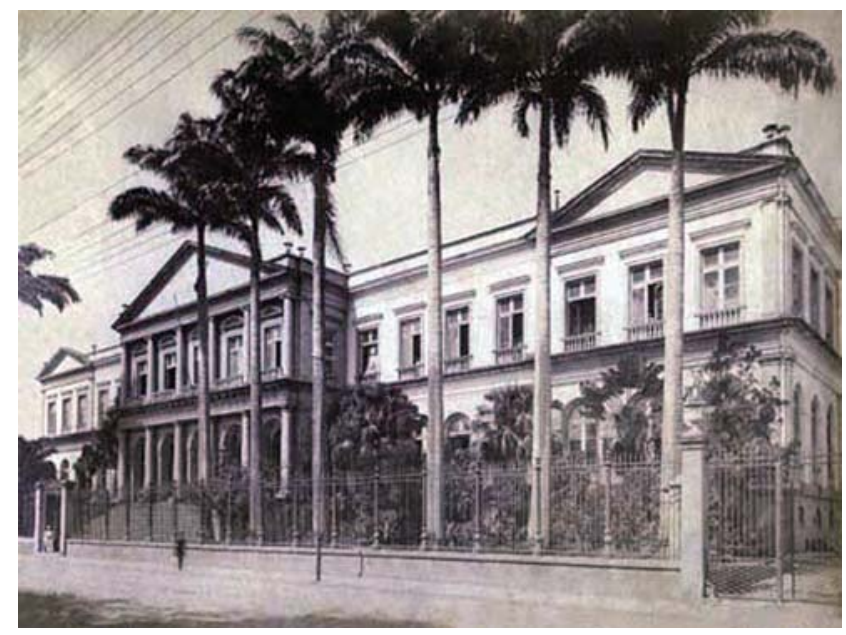

Figura 8 - Juan Gutierrez, Casa da Moeda, c. 1893, Rio de Janeiro. $20 \times 25 \mathrm{~cm}$, papel albuminado. Acervo do Museu Histórico Nacional, Rio de Janeiro, disponível em: <http:// www. museu historiconacional.com.br>.

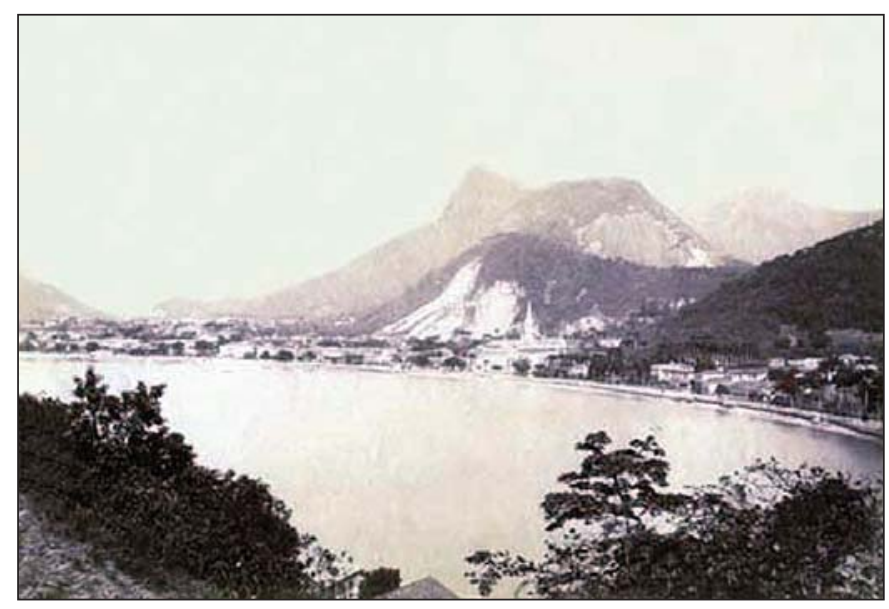

Figura 10 - Juan Gutierrez, Enseada de Botafogo, c. 1893, Rio de Janeiro. $20 \times 25 \mathrm{~cm}$, papel albuminado. Acervo do Museu Histórico Nacional, Rio de Janeiro, disponível em: <http://www. museuhistoriconacional.com.br>.

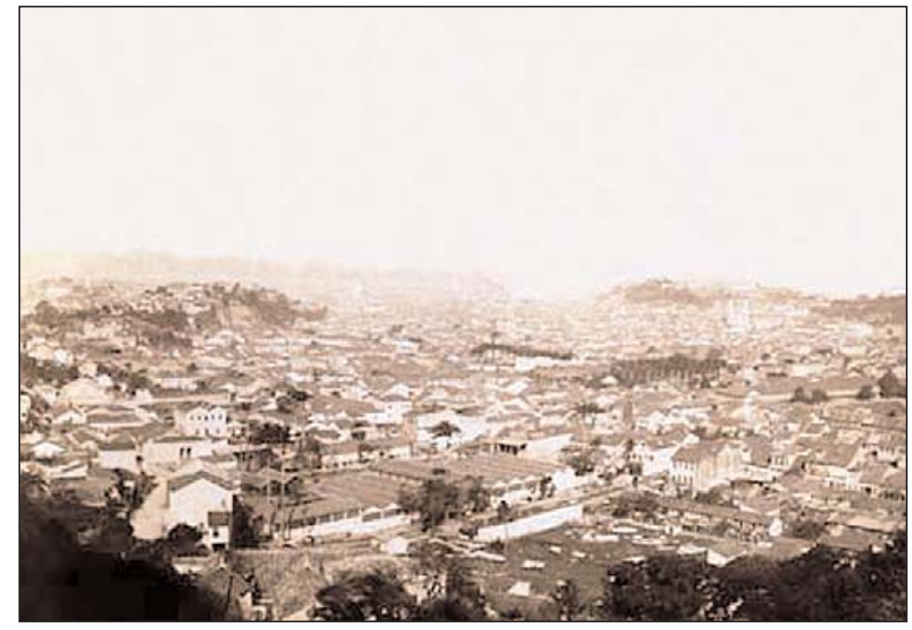

Figura 9 - Juan Gutierrez, Panorama do centro da cidade do Rio de Janeiro, c. 1893, Rio de Janeiro. $20 \times 25 \mathrm{~cm}$, papel albuminado. Acervo do Museu Histórico Nacional, Rio de Janeiro, disponível em: <http://www.museuhistoriconacional.com.br>. No centro, em segundo plano, palmeiras do palácio do barão de Itamaraty, construído em 1855.

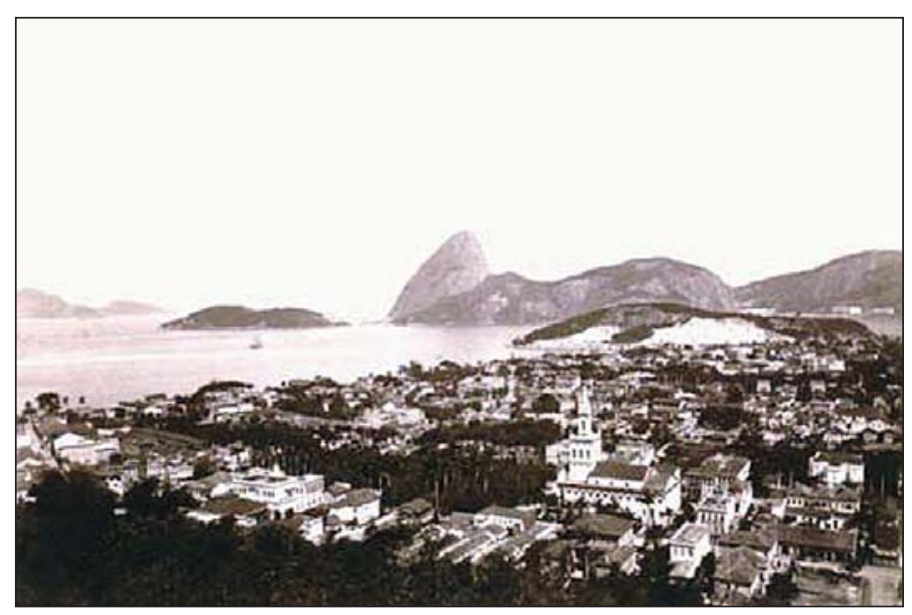

Figura 11 - Juan Gutierrez, Panorama do Flamengo e de Laranjeiras, c. 1893, Rio de Janeiro. $20 \times 25 \mathrm{~cm}$, papel albuminado. Acervo do Museu Histórico Nacional, Rio de Janeiro, disponível em: <http://www.museuhistoriconacional.com.br>. Em primeiro plano, igreja de N. S. da Glória e palmeiras do Largo do Machado.

em aléias ou renques, demonstrando o sucesso do arranjo original do Jardim Botânico. Em outra imagem, é retratado o largo do Machado, com seu exuberante agrupamento de palmeiras (Figura 11 ).

Outro fotógrafo que nos legou registro considerável da Corte fluminense foi Marc Ferrez. Em um dos muitos panoramas que produziu, destaca-se um, 


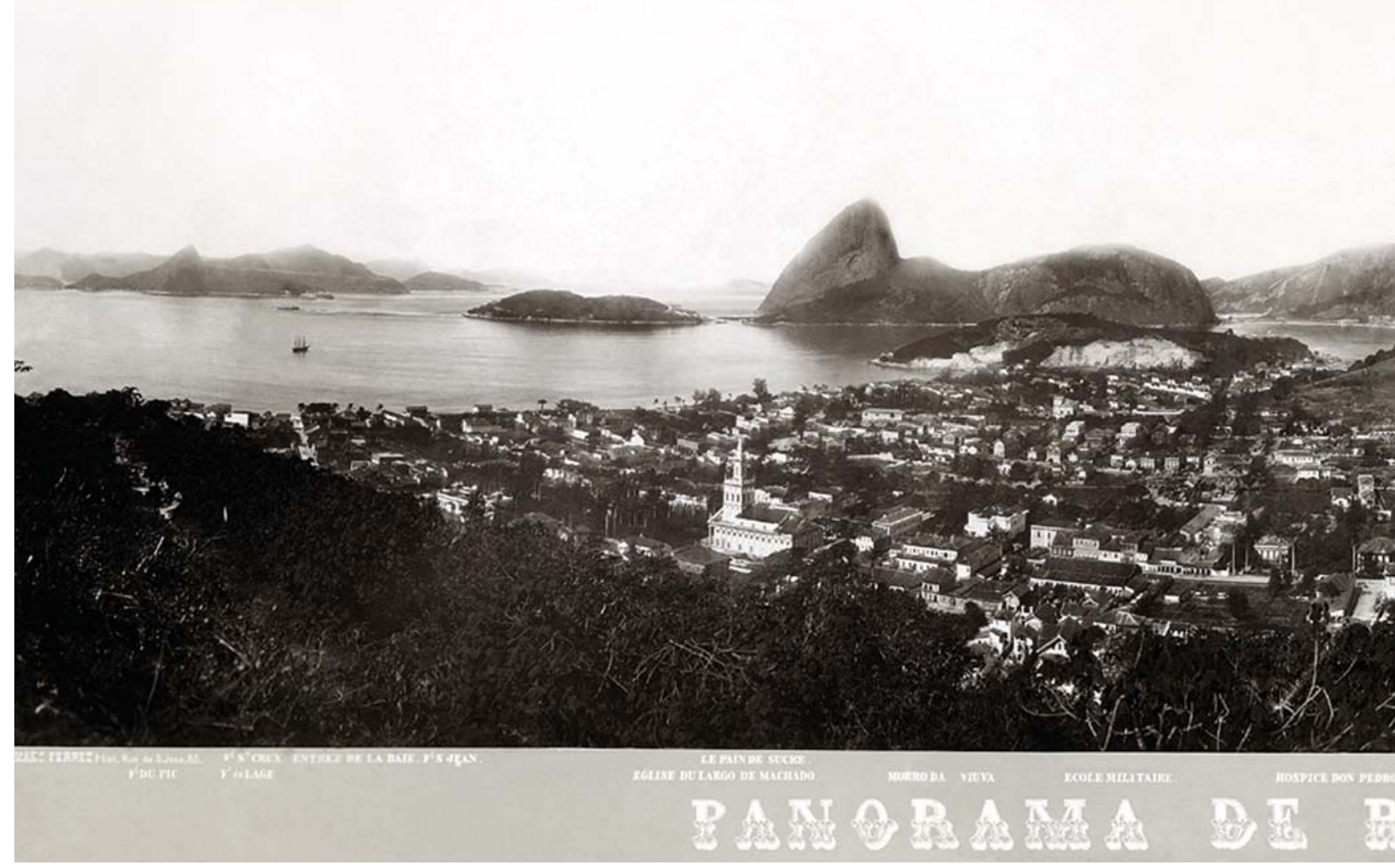

Figura 12 - Marc Ferrez, Panorama do Rio de Janeiro, c. 1880, Rio de Janeiro. $38 \times 105 \mathrm{~cm}$, albúmen. Coleção Gilberto Ferrez. Acervo do Instituto Moreira Salles, Rio de Janeiro. À esquerda, Igreja de N. S. da Glória e palmejras do Largo do Machado.

intitulado Panorama de [sic] Rio de Janeiro (O BRASIL..., 2005, p. 144-145). Realizado por volta de 1880, mostra as fortalezas da Laje e de Santa Cruz, o largo do Machado, a Escola Militar, o hospício D. Pedro e o bairro de Laranjeiras, tendo ao fundo o Pão de Açúcar. Nessa imagem, de excepcional qualidade e nitidez, pode-se contar, com certeza, cerca de onze conjuntos de palmeirasimperiais, adornando espaços públicos e também jardins particulares. As plantas mostradas são adultas, iá perfeitamente formadas, o que leva a crer que tenham sido plantadas em meados do século XIX (Figura 12).

Para confirmar a hipótese sobre a data de plantio, recorreu-se ao trabalho de Augusto Stahl, cujos registros - anteriores aos de Ferrez e Gutierrez - foram realizados em meados da década de 1860. Este fotógrafo também produziu registros da praia de Botafogo, nos quais quase não se nota a presença das palmeiras. Em uma das fotos (uma tomada mais aproximada, realizada em 


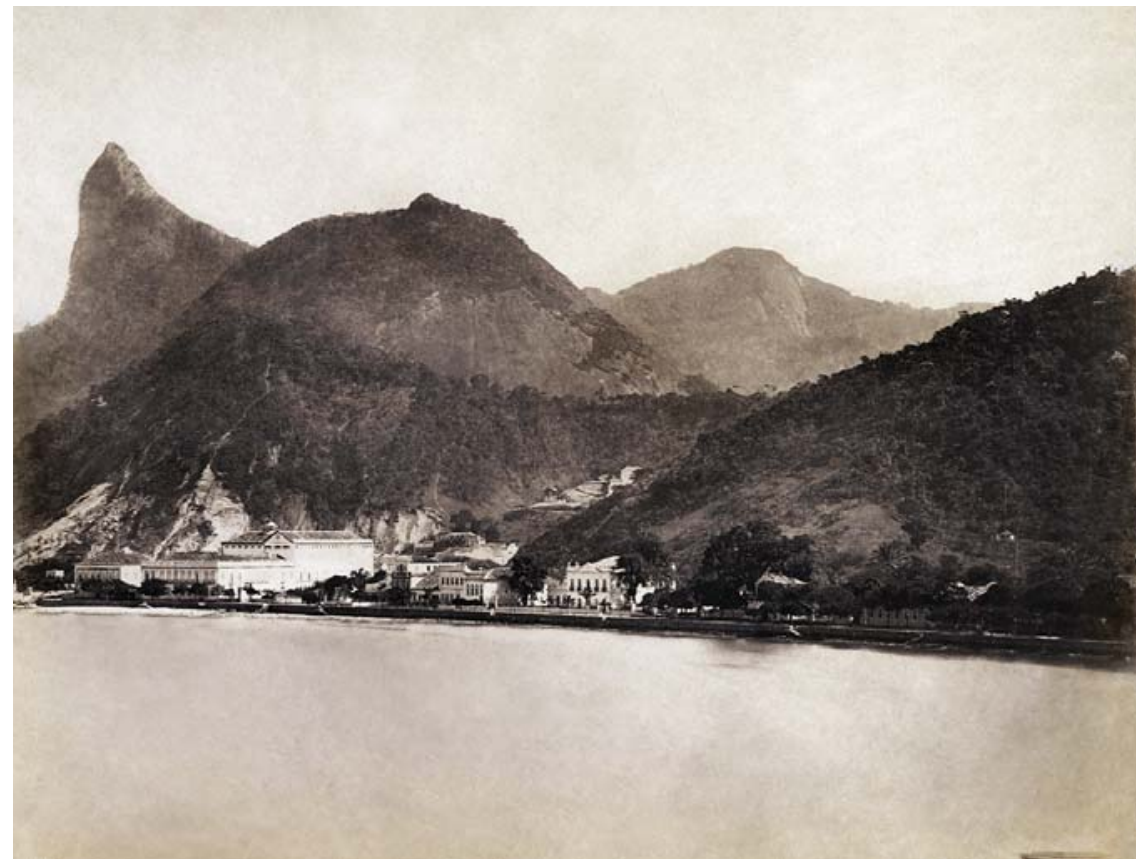

Figura 13 - Augusto Stahl, Praia de Botafogo, c. 1865, Rio de Janeiro, 19,8 × 24cm, albúmen. Coleção Gilberto Ferrez. Acervo do Instituto Moreira Salles, Rio de Janeiro.

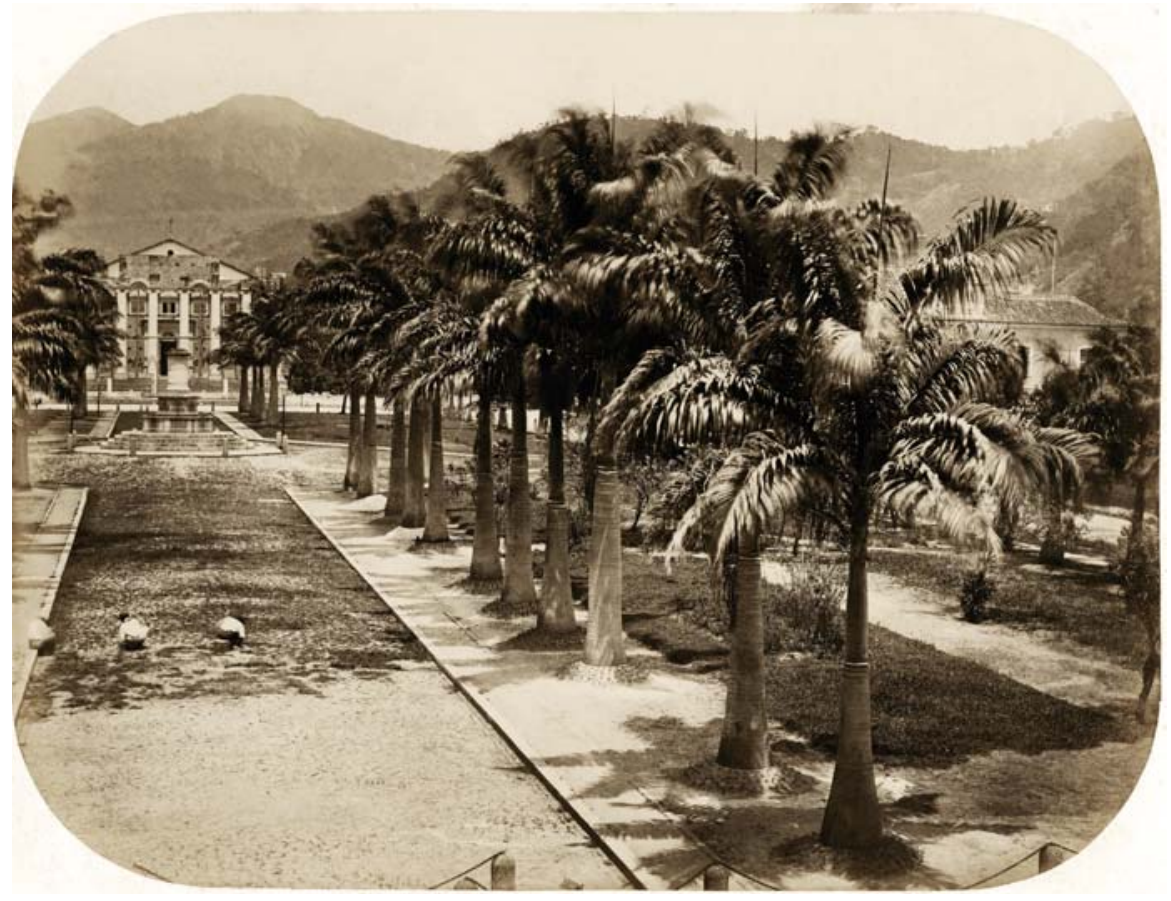

Figura 14 - Augusto Stahl, Largo do Machado, c. 1863, Rio de Janeiro. 19,7 × 26, 1cm, albúmen. Coleção Gilberto Ferrez. Acervo do Instituto Moreira Salles, Rio de Janeiro. 
ou lealdade ao poder central. Afinal, é nesse período que se inicia a distribuição de títulos de nobreza. Uma tentativa, pode-se supor, de formar uma corte sintonizada com o jovem imperador.

Somente na década de 1850, como veremos adiante, foram distribuídos um total de 160 títulos nobiliárquicos (MOURA, 2002). Então, porque não também distribuir um símbolo que conferisse visibilidade, de fato, ao agraciado?

Por essa época, o café já se tornara um produto rentável, ocupando grandes áreas da província fluminense e, extravasando suas fronteiras, estava sendo plantado em Minas Gerais e no Vale do Paraíba paulista. A configuração paisagística baseada no Jardim Botânico do Rio de Janeiro será repetida nas cidades e fazendas da porção fluminense do Vale. Em uma imagem de Marc Ferrez, está registrada a existência, por volta de 1890, de um grupo de palmeirasimperiais em uma fazenda de café dessa região (Figura 15).

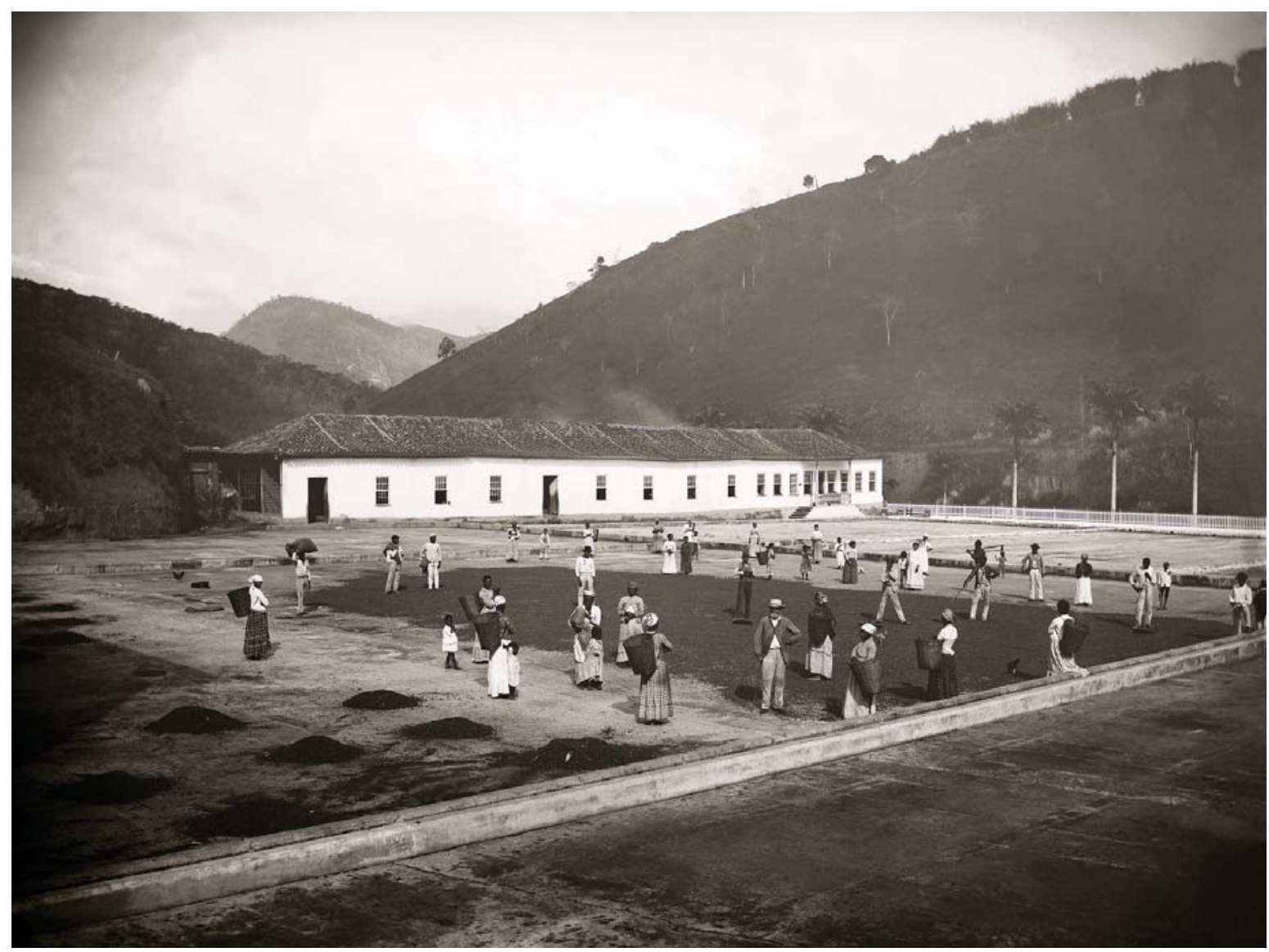

Figura 15 - Ao fundo, junto à sede, conjunto de palmeiras. Marc Ferrez, Fazenda de café, c. 1890, Rio de Janeiro, $30 \times 40 \mathrm{~cm}$. Negativo original em vidro. Gelatina/prata. Coleção Gilberto Ferrez. Acervo do Instituto Moreira Salles, Rio de Janeiro. 
7. Essa expressão foi cunhada por Ernani Silva Bruno, em referência aos mineiros que, esgotado o ouro, deixaram Minas Gerais e fixaram-se em São Paulo, e que, na realidade, seriam paulistas ou filhos destes, que se deslocaram em direção às mi nas, em busca do ouro. Cf. Bruno (1967). A expres são também é empregada em Lemos (1999).

8. O café teria chegado a São Paulo aproximadamente entre $1790 \mathrm{e}$ 1797. Cf. Bruno (1967).

9. Para a história da abertura do Caminho Novo da Piedade, ver Reis [1971].

10. A esse respeito, ver Fania Fridman (1999). café transformador

Com a exaustão do ciclo aurífero em Minas Gerais, o Vale do Paraíba paulista passa por uma crise econômica, já que muito do sustento de seus habitantes estava ligado ao trânsito de tropas em função do ouro e, mesmo, à suprir as demandas dos núcleos mineradores - que, como é sabido, tinham baixíssima produção agrícola, enfrentando, de tempos em tempos, crises de abastecimento. Apesar da queda do movimento diretamente ligado ao ouro vindo de Minas Gerais, algumas atividades continuaram a existir, como foi o caso do comércio de muares entre o Rio Grande e o Rio de Janeiro.

Assim, os chamados "torna-viagem"7, acabaram por fixar-se no Vale do Paraíba e passaram à exploração da atividade agrícola, em função do fluxo de viajantes que existia entre São Paulo e Rio de Janeiro. Outra ocupação que garantia a subsistência, principalmente da população fixada à beira das estradas e caminhos, era a venda de mantimentos para tropas e viajantes. Deste modo, a região vale-paraibana pôde sobreviver até ser alcançada pelo surto do café.

A introdução da cultura cafeeira na região, ainda de maneira incipiente, inicia-se nesse período ${ }^{8}$ e, em 1836, havia ocupado todo o Vale, provocando uma sensível alteração da paisagem, pela necessidade da derrubada de áreas de floresta para a lavoura. Tal processo ocorre no sentido inverso ao do povoamento, isto é, desde a divisa com o Rio de Janeiro em direção à cidade de São Paulo. Principalmente pelo interesse dos paulistas em ter uma ligação terrestre entre São Paulo e Rio de Janeiro - e às custas destes, levando 52 anos para ser concluído - é aberto o Caminho Novo da Piedade, que desempenha o papel de importante vetor de penetração da cultura cafeeira na província paulista. Saint-Hilaire (1974) registrou suas impressões, em 1822, em sua viagem de São Paulo para o Rio de Janeiro, afirmando que era a partir de Lorena que podiam ser encontrados homens ricos, que deviam sua fortuna à cultura cafeeira; indica, ainda, que as fronteiras de seu cultivo já se encontravam, à época, nas proximidades de Jacareí.

Ainda assim, ao comparar-se o processo de expansão da cultura cafeeira na parte paulista do Vale do Paraíba em relação à sua porção fluminense e ao Oeste Paulista, é possível notar que, no Vale, ela deu-se de forma muito mais lenta. Essa lentidão pode ser atribuída à carência de capitais dos lavradores vale-paraibanos, cujos ganhos com a economia açucareira estavam aquém daqueles auferidos em outras regiões paulistas, notadamente na região de Piracicaba e ltu, pois a acumulação de capital oriundo da cultura canavieira foi um dos fatores que possibilitou aos fazendeiros paulistas o investimento no café (CANABRAVA, 1967).

Em contrapartida, o capital dos fluminenses tinha origem bem diversa: em boa parte, os fazendeiros do Rio de Janeiro eram portugueses vindos com a Corte e, tendo recebido terras de D. João VI, acabaram acumulando fortunas pela divisão das suas sesmarias ${ }^{10}$. 
Richard Morse (1970), ao discutir a entrada da cultura do café em São Paulo, assinala que, até a instalação da ferrovia, a região do Vale do Paraíba era "tributária do Rio", tanto por terra quanto por mar, e chama a atenção para a "unidade geográfica da região e seus escoadouros marítimos naturais: o Rio e através da serra do Mar - Angra dos Reis, Parati, Ubatuba, Caraguatatuba e São Sebastião". O Vale mantinha uma estreita ligação com o Rio de Janeiro, a ponto de seus moradores enfrentarem a penosa viagem para a Corte para suprirem-se das "novidades fluminenses e européias" (MAIA; HOLANDA, 1975, p. 29).

Essa relação só se invertia a partir de Taubaté, que mantinha vínculos consolidados com São Paulo. Para o médio e o fundo do Vale, os negócios fluíam mais facilmente com o Rio de Janeiro. Essa forte vinculação pode ser atribuída ao fato de que, para se alcançar a Corte, fosse necessário ir a Parati e, de lá , seguir por mar. Mesmo assim, esse trajeto seria mais fácil e rápido do que tentar alcançar São Paulo pelo caminho aberto pelos bandeirantes, a Estrada Geral.

Além do mais, a capital paulista, ainda paupérrima nesse período, não oferecia atrativos como a Corte, de onde provinham os melhores artigos para o comércio vale-paraibano, desde as "as bretanhas, as gangas", os tecidos de seda, os maços de fitas, os barris de vinho, a aguardente do Reino", até "as arrobas de bacalhau". Em contrapartida, do Vale partiam açúcar, fumo, toucinho e algum café (EVANGELISTA, 1978, p. 44).

Depois da expansão da fronteira da lavoura cafeeira do Vale do Paraíba em direção ao Oeste Paulista, a partir de meados do século XIX, a produção da Província de São Paulo finalmente superou a fluminense. Isso ocorreu por volta da década de 1880, muito por conta da admissão de mão-de-obra livre e do investimento efetuado na ampliação da malha ferroviária. Pouco antes, porém, da riqueza do café alcançar a região da Mogiana, o Vale do Paraíba sentiu seus reflexos, com a ampliação dos contingentes populacionais urbanos. Para isso concorreram, inclusive, os mineiros do sul que, abandonando de vez a exploração do ouro, trouxeram também os seus escravos.

Desde a sua chegada, o café proporciona a melhoria das condições de vida dos habitantes do Vale do Paraíba, em sua porção mais oriental, na região que vai de Lorena até a divisa com a província do Rio de Janeiro. Assim, obtidos os primeiros lucros da cultura cafeeira, surge uma elite abastada, que passa a investir nos núcleos urbanos vale-paraibanos como forma de demonstração de poder e prestígio locais.

Mesmo assim, continua a influência fluminense no fundo do Vale do Paraíba paulista. Apesar de "encravadas" em território bandeirante, os usos e costumes são os da província fluminense e infiltram-se no cotidiano daquelas cidades; e nas relações e atividades que lá se desenrolam (ZALUAR, 1975). Mais um motivo, portanto, para a utilização das palmeiras na região, onde serão utilizadas em toda a sua extensão, difundindo-se no sentido Bananal-São Paulo. 
12. Na direção inversa, hoje são plantados novos conjuntos, com o claro intuito de criar uma atmosfera propícia para a exploração turística ou que remeta à época do fausto cafeeiro, reiterando o poder simbólico da palmeira-imperial
A difusão das palmeiras pelo Vale do Paraíba

Embora estudando o caso lorenense mais detidamente, é importante trazer outros exemplos da utilização das palmeiras-imperiais no Vale do Paraíba. Pode-se supor que os primeiros exemplares começaram a ser plantados a partir do final dos anos 1870, após a instalação da ferrovia e já na fase áurea da cafeicultura na região. Ou seja, somente depois de terem sido formadas as grandes fortunas.

Através de imagens remanescentes do período, é possível inferir que os conjuntos plantados nas diversas cidades sejam contemporâneos. Não foi possível comprovar ainda qual foi a lógica de entrada da espécie na região, isto é, se as palmeiras foram sendo plantadas à medida que a cultura cafeeira avançava em direção à São Paulo, ou se o plantio dos conjuntos ocorreu segundo a disponibilidade do aporte financeiro destinado, pela elites locais, ao embelezamento dos centros urbanos de suas cidades. Até o momento, preliminarmente, o que se apurou foi a data de plantio das palmeiras de Taubaté e Lorena, sendo as primeiras aparentemente anteriores às lorenenses - 1881 e 1884, respectivamente.

Também é possível observar que o plantio, via de regra, segue o modelo consagrado do Jardim Botânico do Rio de Janeiro. Por exemplo, ambas, Taubaté e Lorena, têm uma rua das Palmeiras, nome esse adotado pelas respectivas populações locais (Figura 16).

Foram plantadas palmeiras em praticamente todas das cidades valeparaibanas ou, pelo menos, nas mais antigas, o que confere à região uma coerência paisagística notável. Essa característica, associada à morfologia do Vale entre Cruzeiro e Jacareí, e aos aspectos históricos comuns entre todas, resulta em um grande território homogêneo, patrimônio cultural e paisagístico que deveria ser preservado como testemunho da primeira era cafeeira paulista.

Infelizmente, em alguns casos, como em Bananal, por exemplo (Figura 17), tais configurações paisagísticas não foram devidamente respeitadas enquanto parte da herança cultural da cidade e acabaram sendo arrancadas e substituídas por composições "mais modernas"12.

Outros exemplos de cidades que se valeram da palmeira-imperial como elemento qualificador de seus espaços públicos foram Guaratinguetá (Figura 18), vizinha a Lorena pelo Oeste, mas com um conjunto muito menos expressivo; e Pindamonhangaba (Figuras 19 e 20), que conta com um dos melhores exemplares de arquitetura da época, o palacete do barão de Lessa, conhecido também pelo sugestivo nome de Palacete Palmeira. 


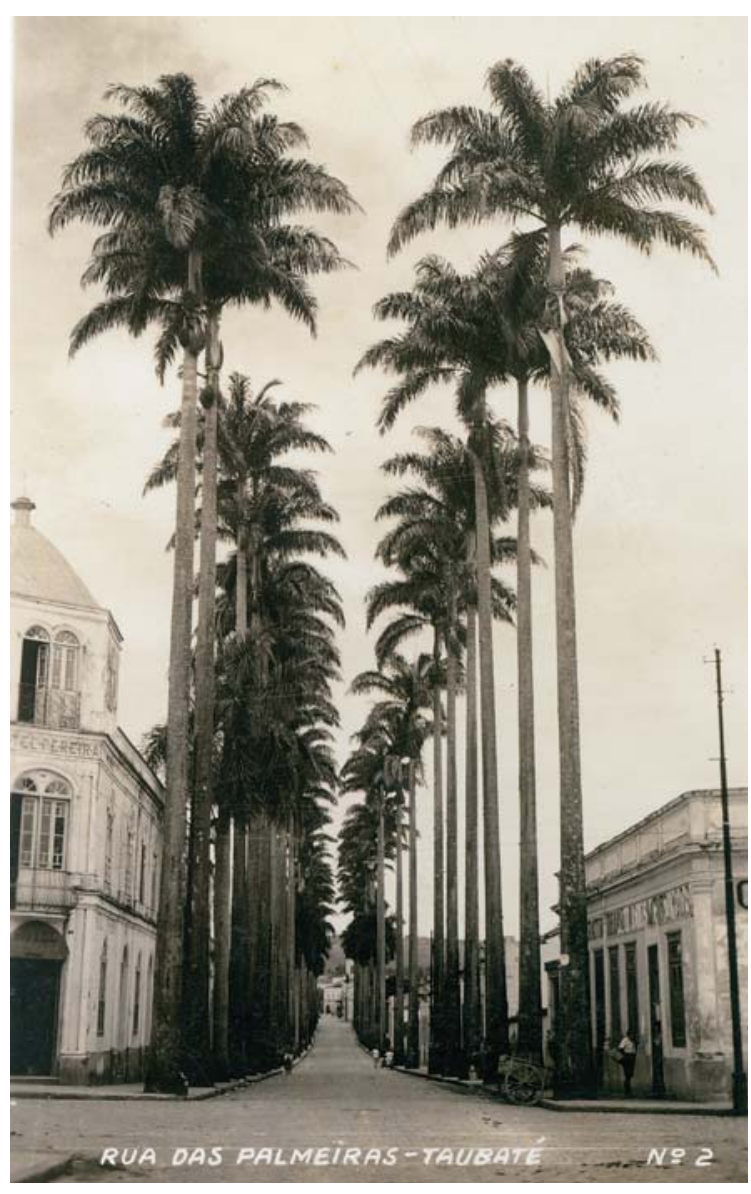

Figura 16 - Rua das Palmeiras. Taubaté. Cartão postal, s.d., Taubaté, SP. Acervo do Museu Paulista da Universidade de São Paulo.

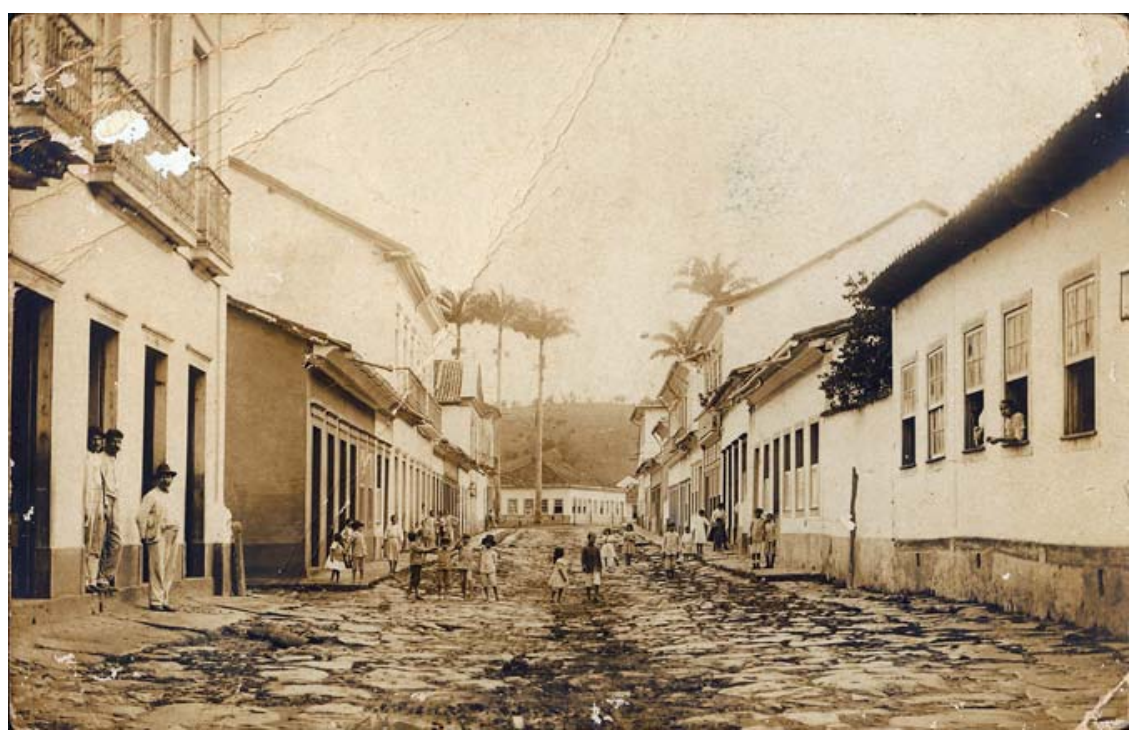

Figura 17 - [Sem título]. Cartão postal, s.d., Bananal, SP. Acervo do Museu Paulista da Universidade de São Paulo. 


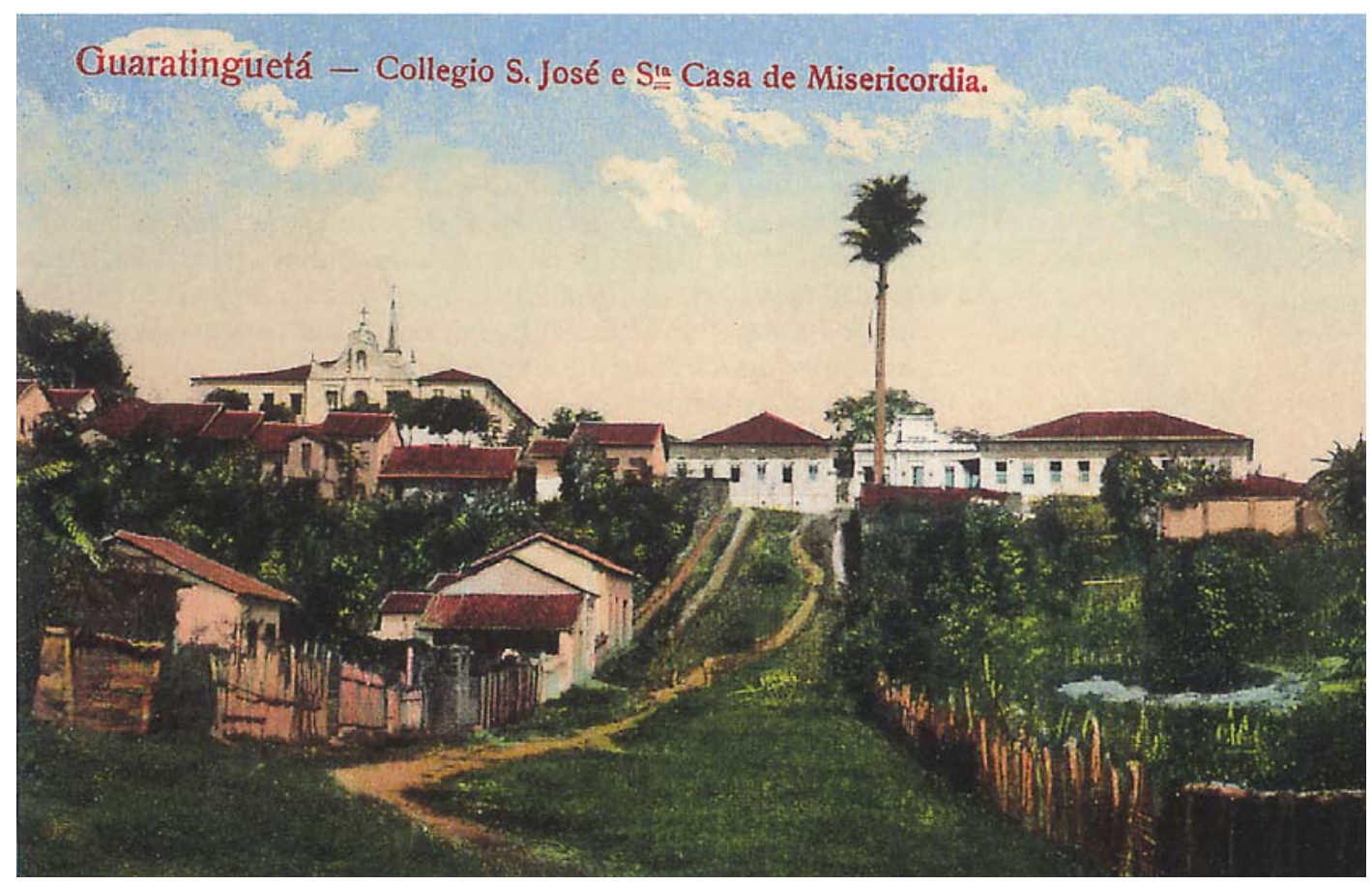

Figura 18 - Guaratinguetá. Collegio S. José e Sta. Casa de Misericordia. Cartão postal, c. 1910, Guaratinguetá, SP (GERODETTI; CORNEJO, 2003, p.71).

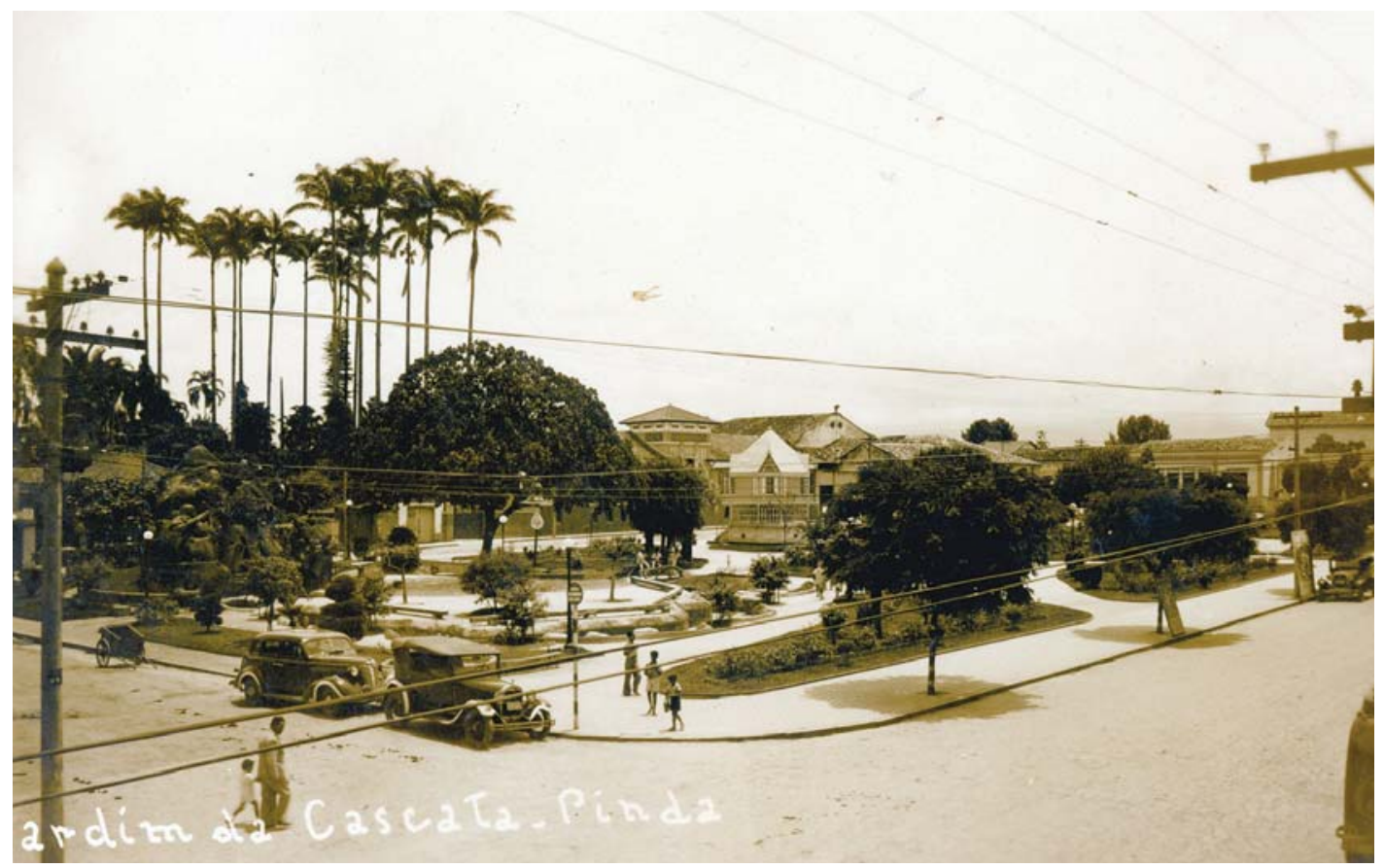

Figura 19 - Jardim da Cascata. Pindamonhangaba. Cartão postal, s.d., Pindamonhangaba, SP. Acervo do Museu Paulista da Universidade de São Paulo. 


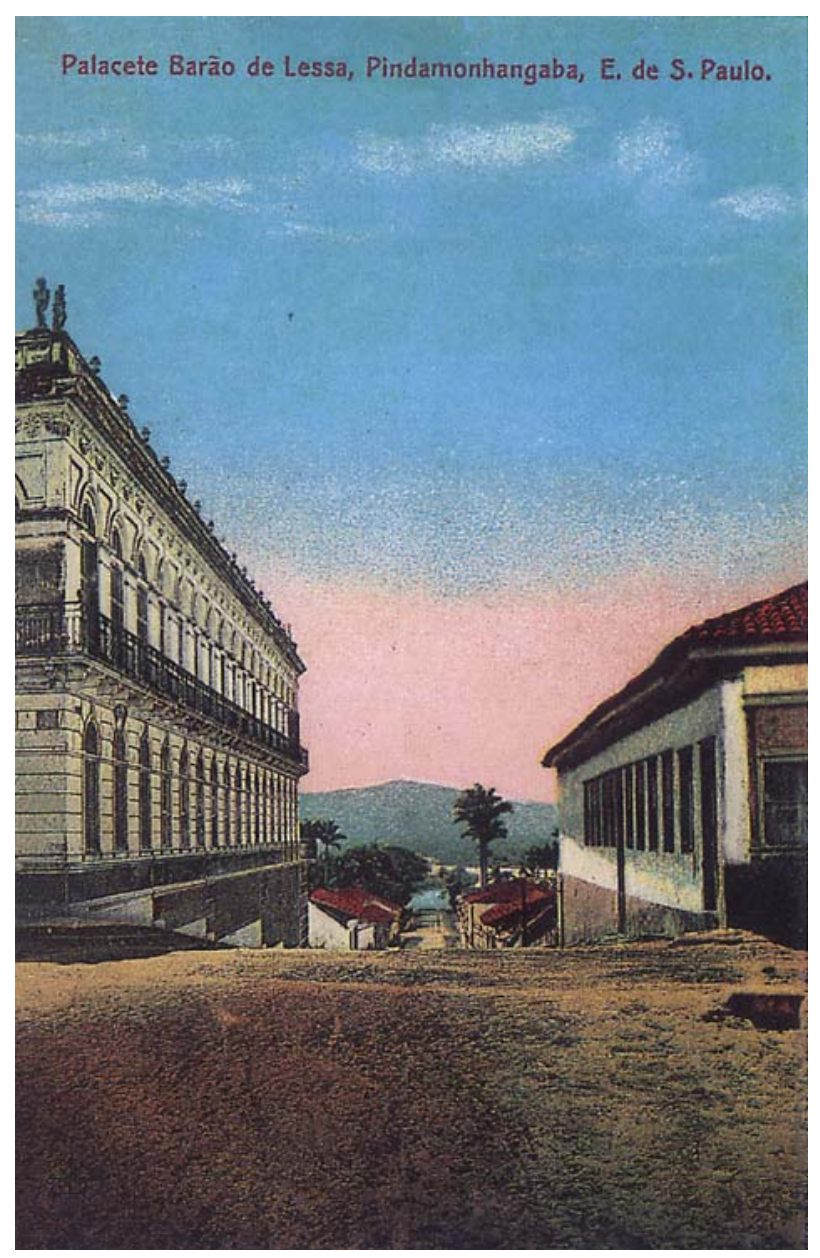

Figura 20 - Palacete Barão de Lessa, Pindamonhangaba, E. de S. Paulo, Cartão-postal, c. 1915, Pindamonhangaba, SP (GERODETTI; CORNEJO, 2003, p.61).

baronato local: agente do melhoramento da cidade

Foram de importância fundamental para o desenvolvimento das sociedades vale-paraibanas a atuação do baronato local e o papel que ele desempenhou, financiando boa parte dos melhoramentos urbanos e agindo na propagação do novo gosto europeizado vindo da corte ou diretamente da Europa.

A respeito da formação desse baronato, convém esclarecer que os títulos nobiliárquicos no Brasil diferem dos portugueses em alguns pontos. Por aqui, eles não podiam ser comprados, apesar de muitas vezes terem sido outorgados em troca de "atos de lealdade" ou mesmo doações ao Império. Também a nobreza brasileira não tinha direito automático a assentos no Senado, 
13. Cf. as transcrições de: Carta de Mercê do Título de Barão de Moreira Lima, de 28 de abril de 1883; Carta de Mercê do Título de Visconde de Moreira Lima, de $1^{\circ}$ de março de 1884; e Carta de Mercê da Comenda da Ordem de Christo [ao Visconde de Moreira Lima], de 14 de outubro de 1884, em Rodrigues (1942, p. 164-165) ou outros papéis legislativos, mas seus filhos podiam ingressar no Exército ou na Marinha como cadetes ou aspirantes, respectivamente. O valor do título estava ligado mais ao prestígio social e à conseqüente facilidade para acesso à vida da corte e às esferas mais altas do mundo político e econômico (MOURA, 2002).

Moura (2002, p. 104) informa que tais títulos foram distribuídos com certa parcimônia, principalmente no Segundo Império, devido à indiferença de D. Pedro Il em relação às questões cerimoniais. Tal atitude teria levado o monarca a perder um forte "instrumento de estabilidade política". O autor distingue, no Segundo Império, quatro principais momentos em que ocorreram as "ocasiões de amerceamento", referidas a fatos políticos importantes no relacionamento entre os proprietários locais e a Corte, o que, de certa maneira, contradiz sua afirmação anterior sobre o descaso do Imperador.

O primeiro momento ocorreu na década de 1850, quando houve um grande número de concessões, num total de 160 títulos distribuídos em todo o Brasil. A generosidade dessa distribuição pode estar ligada a um movimento, desde a Corte, no sentido de prestigiar a elite agrária paulista, composta por senhores de engenho e fazendeiros de café, justamente no momento em que essa segunda lavoura passava a ter participação preponderante na balança de exportações brasileira (MOURA, 2002). Outra razão plausível para tal distribuição, como já afirmado anteriormente, poderia estar ligada à recente maioridade de D. Pedro II, no sentido de que se garantisse um ambiente amistoso ao novo Imperador.

No período em que se desenrolou a Guerra do Paraguai, nenhum título foi outorgado. Findo o conflito, entre os anos de 1867 e 1871, há uma segunda distribuição de títulos e condecorações, pela contribuição dos fazendeiros vale-paraibanos à causa, enviando homens e fazendo doações vultosas para a compra de armamentos e fardas.

O momento seguinte decorre da concretização da ligação ferroviária entre Rio de Janeiro e São Paulo, em 1877, face às doações para a construção da ferrovia. Neste terceiro momento, são agraciadas personalidades importantes da cidade de Lorena:

[A] doação de grandes somas para a construção de templos religiosos la matriz, em que se empregou material diretamente importado da Europa, e a igreja de São Benedito, cujo risco foi entregue ao francês Charles Peyrouton, o mesmo que projetou o palácio dos Condes de Nova Friburgo, no Rio - o atual palácio do Catete - e o palacete do Barão de Lessa, em Pindamonhangaba) e, sobretudo, a inauguração de um Engenho Central, iniciativa das famílias Castro Lima e Vicente de Azevedo, resultaram na concessão de numerosos títulos e ordens honoríficas, entre os anos de 1879 e 1884. Criaram-se os títulos de Viscondessa de Castro Lima, Barão de Moreira Lima (logo elevado a Visconde) ${ }^{13}$ e segundo Barão de Castro Lima, além do que numerosas comendas e oficialatos da Rosa e de Cristo foram distribuídos entre seus próximos parentes (MOURA, 2002, p. 105).

O quarto e último momento, entre 1883 e 1889, é marcado pela tentativa de contenção dos ânimos mais exaltados, pela ampla e generosa outorga de títulos, em função da crescente pressão abolicionista, contrária aos 
interesses da imensa classe dos proprietários rurais. Nesse instante, o visconde de Moreira Lima passa a conde de Moreira Lima ${ }^{14}$; ao lado do conde de Santo Agostinho, de Taubaté, são as únicas personalidades da região agraciadas com esta alta titulação.

É curioso que os lorenenses tenham se destacado, segundo Moura (2002), pela sua religiosidade, inclusive porque a nova lgreja Matriz é posterior a esse período - as obras estenderam-se de 1886 a 1890. Porém, tal razão é confirmada pelo exame das transcrições das cartas de amerceamento inclusas no texto de Rodrigues (1942)15; aí se pode observar que a concessão dos títulos tem mesmo um caráter religioso. Contudo, parece haver um fundo político nessas titulações, pois a família Castro Lima praticamente controlava a cidade, e o conde de Moreira Lima era o grande benemérito local, financiando inclusive as obras públicas, como consta no seguinte trecho de uma Ata da Câmara, datada de $1884^{16}$ :

O mesmo Snr Presidente comunicou que a vista da urgencia do cazo, autorizou um emprestimo até a quantia de dusentos mil, para com o Snr. B. de Moreira Lima para melhoramento da praça d'este mesmo nome e pedia approvação d'esta Camara, cuja quantia sera paga em 31 de julho.

Em outra Ata do mesmo ano, foi lido o "offício do Snr Barão de Moreira Lima, agradecendo o porem na nova praça do S. Benedicto, praça do Barão de Moreira Lima"17, prova de sua importância dentro daquela sociedade.

Mas todas as cidades da região tiveram os seus benfeitores. Talvez uma outra explicação possível para o agraciamento dos Castro Lima seria mesmo acreditar em certa predileção pessoal do $\mid m p e r a d o{ }^{18}$ ou, ainda, uma maneira que este encontrou para fazer uma crítica velada à atitude mais "expansiva" de outros "fidalgos vale-paraibanos", pois consta que o conde nunca foi à Europa, viajou poucas vezes ao Rio de Janeiro e tampouco buscou transferir-se para o Oeste Paulista quando o café declinava na região - como o fizeram os Rodrigues Alves, por exemplo -, preferindo investir seu tempo e dinheiro em sua própria cidade.

Um outro ponto a favor dessa hipótese é que o conde não tinha herdeiros, deixando grande parte de sua fortuna para a Santa Casa local, o Asilo São José, o Colégio São Joaquim e o Instituto Santa Carlota, instituições fundadas por ele. Nas palavras de Faustino Cesar (1928, p. 113), "foi um benemérito, pois, quando boas fortunas eram retiradas de Lorena, a procura de melhor colocação, a sua era toda empregada aqui na construção de prédios, revelando assim nobre bairrismo e acendrado amor ao seu torrão natal".

Pela iniciativa da criação do Engenho Central de Lorena, em 1881 , em sociedade com outros notáveis locais, Moreira Lima foi agraciado com a Comenda da Ordem de Cristo ${ }^{19}$ em 1884, ano do início das atividades do engenho.

Na verdade, o conde de Moreira Lima tinha origem um pouco diversa daquela de alguns de seus contemporâneos do Vale, pois não provinha de uma família de agricultores e, antes de entrar para o ramo do cultivo do café, já
14. Cf. Carta de Mercê do Título de Conde de Moreira Lima, de 7 de maio de 1887 (RODRIGUES, 1942, p. 165).

15. "Querendo Distinguir e Honrar ao Major Joaquim José Moreira Lima, em attenção aos relevantes e distinctos serviços que tem prestado á Religião,á instrucção publica e á humanidade: Hei por bem Fazer-lhe mercê do título de Barão de Moreira Lima." Transcrição da Carta de Mercê do Título de Barão de Moreira Lima, de 28 de abril de 1883; "Querendo novamente Distinguir e Honrar ao Barão de Moreira Lima, em attenção aos distinctos e relevantes serviços que tem prestado á Religião, Hei por bem Elevá-lo a Visconde do mesmo nome com as honras de grandeza."Transcrição da Carta de Mercê do Título deVisconde de Moreira Lima, de $1^{\circ}$ de março de 1884 (Idem. p. 164).

16. Ata da Câmara, de 22 de fevereiro de 1884.Arquivo Municipal de Lorena.

17. Ata da Câmara, de janeiro de 1884. Arquivo Municipal de Lorena.

18. Na carta de amerceamento do título de Conde, por exemplo, não é explicitado o motivo do gesto imperial:"Querendo novamente Distinguir e Honrar o Visconde de Moreira Lima, Hei por bem Eleval-o a Conde do mesmo nome. E Quero e Mando que o dito Visconde daqui em diante se chame o Conde de Moreira Lima”. Transcrição da Carta de Mercê do Título de Conde, de 7 de maio de 1887 (Ibidem, p. 165).

19. "Faço saber aos que esta Minha Carta virem que attendendo ao rele- 
vante serviço que o Visconde de Moreira Lima prestou á industria nacional concorrendo para o estabelecimento de um engenho central na Cidade de Lorena, de Província de São Paulo, Hei por bem Nomeal-o Commendador da dita Ordem." Carta de Mercê da Comenda da Ordem de Christo [ao Visconde de Moreira Lima], de 14 de outubro de 1884. (RODRIGUES, 1942, p. 165).

20. "Am ${ }^{\circ}$ e Sr. Inclusa remetto a quantia de um conto quinhentos e desesseis mil e duzentos reis $\mathrm{Rs}$ 1:516\$200 para saldar a minha obrigação, cujo vencimento teve lugar em Maio passado, podendo V.S ${ }^{\text {a }}$ enviar o título della [...] [ass.] José Martiniano de Oliv. Borges." Trans crição de carta a Joa quim José Moreira Lima, sobre pagamento de dí vida por parte do filbo do Visconde de Guaratin guetá, de $1^{\circ}$ de julho de 1864 (MOTTA SOBRINHO, 1967, p.131) havia feito fortuna no comércio, ao lado de seu pai, "manejando capitais, numa casa comercial e financeira, que ao redor de 1864, possuía em seu registro 173 escravos" (MOTTA SOBRINHO, 1967, p. 92), além de acompanhar a política com certo distanciamento, apesar de estar próximo dos liberais. Pelas circunstâncias, também ele acaba plantando e negociando café, em razão da aquisição de terras por execução de dívidas, de modo que somava, no fim da vida, mais de trinta fazendas em seu nome.

Antes de cafeicultor, Moreira Lima era um empresário e financista, como prova sua conduta no caso do endividamento do filho do visconde de Guaratinguetá, de quem havia tomado a Fazenda Três Barras como pagamento de dívida. Ajuda o devedor a recuperar sua propriedade, que será mais tarde dos seus genros, Virgílio e Francisco de Paula Rodrigues Alves. Tal auxílio, depreende-se da leitura do texto de Motta Sobrinho (1967, p. 92), foi oferecido na forma de um prolongamento do prazo e conseqüente ajuste de valores: "não perde a base de sua fortuna o vizinho, e obtém vantagem financeira o credor"

Moreira Lima dividia seu tempo "entre a direção e a administração das obras de caridade e das suas próprias, pois, foi elle um hábil construtor, embellezando Lorena com elevado nome os optimos e lindos prédios solidos e confortáveis" (CESAR, 1928, p. 1 13). Mais um dado que corrobora a idéia de que Moreira Lima era na verdade um financista - e esta talvez seja a mais forte razão para o seu reconhecimento por parte do Imperador, garantindo-the a outorga do título de Conde. É a conclusão a que chega Evangelista (1978, p. 95), ao afirmar que:

A produtividade dos cafezais do Vale do Paraíba sempre foi baixa e tenderá a diminuir com o envelhecimento e a erosão dos solos, o que explicaria que a riqueza não virá diretamente da lavoura mas de benefícios originários da movimentação dos capitais e da comercialização do produto; [...] a abastança ficará nas mãos dos poucos que fornecerão dinheiro e receberão os juros para compra de escravos e que possam adquirir o produto na fonte $[\ldots]$.

Na época em que o conde redigiu seu testamento, em 1922, era credor das seguintes dívidas, relacionadas com instituições que ajudara a financiar ou financiara totalmente. Diz ele:

A Matriz desta cidade me é devedora de Rs.30:906\$700, importancia adiantada para sua terminação, no anno de 1889, e que tinha de ser recebida por meio do benefício de 30 contos de réis de uma loteria estadoal que the estava á annos concedida, e que [...] não chegou às minhas mãos [...]. Não cogitei absolutamente do emprego de meios judiciais para a arrecadação desse dinheiro, do qual ao contrario, fui prompto a desistir, e isso de muito bom grado, considerando como um donativo, e muito bem applicado á tão boa obra [...]. A Santa Casa de Misericordia desta Cidade, de que sou Provedor, segundo as contas fechadas a 31 de Janeiro p.p. me é devedora da quantia de Rs. 30:474\$018, de dinheiros adiantados para melhoramentos e custeio; e as obras do Asylo [...], de Rs.82:395\$163 tambem de adiantamentos para continuação das obras [...]. A Conferencia de São Vicente de Paulo, de que sou Presidente, me é igualmente devedora da quantia de Rs. 10:952\$901, adiantada para a distribuição regular dos generos de consumo ás 60 familias matriculadas [...]. Sempre 
foi minha intenção, ao concorrer para os bons Templos que existem em Lorena, dotal-os de casas proximas e decentes para os seos parochos ou capellãis, e assim o consegui de modo satisfactorio, á respeito da Matriz e S. Benedicto [...], o mesmo se dando á respeito da Capella do Rosario, que por minha iniciativa e auxilio, ajudado com esmollas dos bons conterranios, tambem possue o seo bom predio [...] lapud RODRIGUES, 1942, p. 177).

Resultaram, então, aproximadamente 153 contos de réis investidos em obras sociais e de caridade, além de créditos em dinheiro e em terras, que havia para receber, de empréstimos pessoais e de dívidas executadas judicialmente. Não haveria de querer estabelecer-se no Oeste Paulista. A região de Lorena era a sua praça de negócios.

Além de Joaquim José Moreira Lima Jr., conde de Moreira Lima (Figura 21 ), receberam mercê sua mãe, D. Carlota Leopoldina de Castro Lima, como

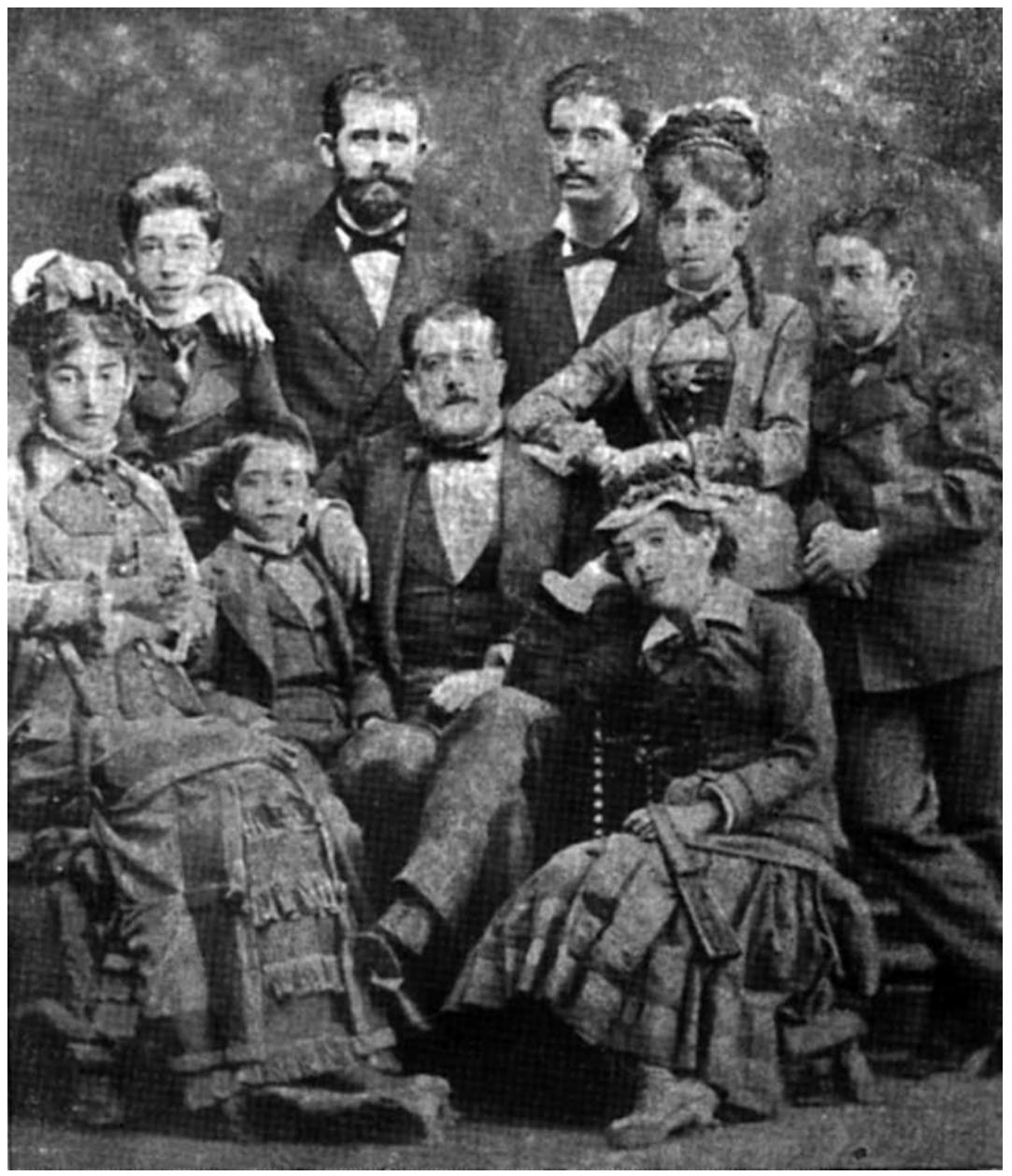

Figura 21 - Castro Lima está sentado, ao centro. De pé, à esquerda, está seu irmão e genro, o Conde de Moreira Lima. A família do Barão de Castro Lima, c. 1875, Lorena, SP (MOTTA SOBRINHO, 1967, p.89). 
21. Para entender aspectos genealógicos dos Castro Lima, Moreira Lima e Azevedo, ver Rodrigues $(1942 ; 1956)$ e Motta Sobrinho (1967). viscondessa de Castro Lima, em 1879; seu irmão, Antônio Moreira de Castro Lima, como barão de Castro Lima, em 1884; seu sobrinho Francisco de Paula Vicente de Azevedo, como barão da Bocaina em 1887 e seu primo Antônio Rodrigues de Azevedo Ferreira, feito barão de Santa Eulália em novembro de 1888. Todos ainda agraciados com as comendas da Rosa e de Cristo, entregues inclusive aos também lorenenses Bráulio Moreira de Castro Lima, e Arlindo e Theophilo Braga.

No cenário político nacional, destacaram-se outros entes do clã ${ }^{21}$, sem títulos honoríficos, entre eles Pedro Vicente de Azevedo, que chegou a ser presidente das províncias de Pernambuco, Minas Gerais e São Paulo - nesta última, às portas da República, entre 1888 e 1889.

Esses foram os promotores da transformação da paisagem urbana de Lorena a partir de meados do século XIX. Várias ações concorreram para esse processo: regularização do arruamento, abertura de novos logradouros, pavimentação, iluminação, pontes sobre o rio Paraíba e o ribeirão Taboão, introdução de um código de posturas, criação de praças e seu ajardinamento, construção de novos edifícios; a instituição, como já citado, da Santa Casa de Misericórdia, de escolas masculina e feminina, e de um asilo, além do Engenho Central.

As mudanças se iniciaram a partir da década de 1830, sob a influência cada vez maior da família Castro Lima. Evangelista (1978, p. 49) faz uma breve descrição da área central de Lorena no segundo quartel do século XIX, aproximadamente na década de 1830, em que mostra algumas mudanças ocorridas a partir de então:

As vias do povoado não eram o que hoje aparecem. No Largo da Matriz, por exemplo, o aspecto era outro. A velha igreja não ficava isolada, não existindo a atual rua Conde José Vicente. Por sua vez, não havia rua acompanhando o Paraíba (a ałual Cel. Bráulio). Existia um beco junto ao que foi depois a casa do Barão de Santa Eulália e outro beco, que descia para o Paraíba, onde era o Porto Velho, e que a casa de Joaquim José Moreira Lima [o Conde de Moreira Lima] acabou fechando, mais tarde, embora abrindo passagem maior para o rio, no próprio largo. No lado direito, atuais acomodações da Câmara Municipal, antigo palacete do Cel. Bráulio, não havia o recuo que hoje existe, mantendo-se o alinhamento da rua da Piedade até a [sic] Paraíba, como se dizia então.

Do Largo da Matriz seguia-se pela rua Augusta (atual Pe. Manoel Teotônio) até o Largo do Rosário. Aí estavam o sobrado da Câmara, e a igreja de Nossa Senhora do Rosário dos Homens Pretos. Também o Largo não era o mesmo: a capela tinha uma torre, o prédio da Câmara avançava mais para o centro, deixando um pequeno largo no fundo, onde funcionava aos domingos a 'Quitanda', na qual se compravam os gêneros de alimentação.[...] E só. Dois largos, meia dúzia de ruas, três pontes, duas igrejas pequenas e o sobrado da Câmara.

Lorena era ainda uma vila tropeira, mas iniciando um processo de transformação que só terminará ao fim do século, quando se extingue a atividade cafeeira e, a exemplo de suas irmãs do Vale, entra em um período de estagnação econômica. As primeiras transformações ocorrem ainda de modo lento, mas são indicativas da necessidade de organização espacial da vila pela recente chegada dos impactos da cultura cafeeira. 
Assim, em 1832 é aprovado novo Código de Posturas Municipais, onde é explícita a intenção da normalização do desenho urbano, ao estabelecer regras para a configuração espacial dos logradouros. A largura das ruas foi fixada em trinta palmos ${ }^{22}$, cabendo aos proprietários a manutenção das testadas, o que implicava a manutenção da fachada propriamente dita e a manutenção da área de rua correspondente às casas, que deveriam ser capinadas e não ter 'águas paradas'. Estavam previstas multas no valor de \$500 a 1 \$500, dobrando tais valores no caso reincidência (EVANGELISTA, 1978).

$\bigcirc$ fato que marca em definitivo a disposição local por mudanças é a decisão de se erguer uma ponte para a travessia do rio Paraíba, por se tratar da primeira intervenção de grande porte no desenho da cidade, pois, para a sua construção, "seria preciso abrir uma rua, em direção à cabeceira da ponte, passando por três quintais e ainda derrubando-se uma taipa, para permitir a passagem pela margem do Paraíba até o Largo da Matriz" (EVANGELISTA, 1978, p. 52).

A partir de 1826, corre na Câmara a discussão sobre o melhor local para se erigir a ponte. Um dos ofícios encaminhados à Presidência da Província defendia sua instalação em local mais distante do largo da Matriz, com o argumento de que a obra "iria aformosear a Vila" (EVANGELISTA, 1978, p. 53). Foi somente em 1832 que sua construção foi concluída, então dispensando a utilização de canoas para a travessia do rio, uma despesa da administração municipal. Em termos urbanísticos, a ponte promoveu a abertura de uma nova rua (atual 21 de Abril), por onde era desviado o trânsito de tropas e de animais, liberando o largo da Matriz. Na relação desse mesmo largo com o rio, também houve um ganho, posto que sua margem direita ficou livre do movimento das barcas e cargas (EVANGELISTA, 1978), prestando-se então aos passeios da população. Depois de dezesseis anos, em 1848, a ponte veio a ruir, mas cumpriu importante papel na vida da vila: mudou a rota dos tropeiros, afastando os animais do largo da Matriz, proporcionando-the a chance de firmar-se - sendo o núcleo original da povoação - como logradouro com valor cívico e histórico, que a elite local escolheria para implantar seus palacetes.

Na década de 1840, a produção de café passa a liderar a atividade agrícola da vila, suplantando o açúcar e o algodão. $\bigcirc$ comércio estava mais estruturado, com dez negociantes do ramo de fazendas, enquanto o setor de prestação de serviços volta-se para a agricultura, contando Lorena, na época, com dez ferreiros e dois seleiros. Já o desaparecimento, em apenas vinte anos, de algumas profissões como a de "tecer pano" ou "fiar algodão" - observadas por Saint-Hilaire (1974) em 1822 -, limitando-se as costureiras agora somente à confecção das roupas, é um indício das mudanças que se processavam desde a chegada da corte portuguesa no início do século e que, talvez, somente agora estivessem surtindo seus efeitos em Lorena. "Seria, provavelmente, o resultado da abertura dos portos, que inundou o país com os produtos manufaturados ingleses, especialmente tecidos de algodão de Manchester", observa Evangelista (1978, p. 99). Com relação aos ofícios ligados à arquitetura, nessa década continuava a tradição paulista da taipa, mas contando agora com a mão-de-obra mais qualificada 
23.A elevação à cidade foi declarada pela Lei $n^{\circ} 21$, de 24 de abril de 1856; a Lei $\mathrm{n}^{\circ} 1958$, de 14 de agosto de 1857 , cria o seu termo judiciário (RODRIGUES, 1956, p. 72)

24. Cf. Zaluar (1975, pas$\operatorname{sim})$. de oito carpinteiros, "tão necessários em obras de taipas, que melhoravam o trabalho dos escravos carapinas" (EVANGELSTA, 1978, p. 100).

A partir de meados da década de 1850, as transformações tomam novo vulto, pois em 1856 a vila é elevada a cidade, sendo declarada sede de comarca um ano mais tarde ${ }^{23}$. É nessa década que o Vale alcança o auge de sua capacidade produtiva. A derrocada final só se dará na década 1890, restando alguns anos ainda para a exploração da terra. Em contrapartida, será a partir de agora que ocorrerão os maiores investimentos no melhoramento das cidades vale-paraibanas; e em Lorena não será diferente.

Na década de 1860, a cidade já apresentava contornos diferentes daqueles da antiga freguesia do século XVIII. $O$ viajante que ali chegasse encontraria "extensas e bem alinhadas ruas, soberbos e elegantes prédios, abundantes lojas", apesar de os edifícios públicos estarem aquém do bom gosto que prevalecia nas construções particulares. Por essa época, a cidade contava com um "elegante teatrinho, mandado construir à custa do Sr. capitão José Vicente de Azevedo"24 (outro notável membro da sociedade lorenense, primo do conde de Moreira Lima e chefe do Partido Conservador local): "o Teatro de Lorena, na rua Boa Vista, onde se apresentavam companhias dramáticas e líricas" (EVANGELISTA, 1978, p. 130). A casa tinha duas ordens de camarotes da família, para o qual os escravos transportavam poltronas nobres e cadeiras estofadas. "Além da platéia havia varandas (corredores laterais), onde hoje há freqüentemente frisas" (QUEIROZ, 1969, apud EVANGELISTA, 1978, p. 130). Com aproximadamente treze mil habitantes (no município como um todo, inclusive a área rural), o fausto podia ser medido nas novas casas construídas na cidade:

Entre os prédios que mais merecem mencionar-se pela sua grandeza e elegância de construção, destacam-se os dos Srs. Joaquim José Moreira Lima [o pai], João Batista de Azevedo, Comendador Antonio Clemente dos Santos, digno deputado provincial João José Antunes Guimarães, Joaquim Honorato Pereira de Castro, major Antônio Bruno de Godói Bueno, João José Rodrigues Ferreira, D. Maria Pereira da Guia e Azevedo, Manuel de Oliveira Pinto Junior, Antonio Moreira de Castro Lima, o do Sr. padre Manuel Teotônio de Castro, todos dignos de figurar em qualquer das ruas da capital [Rio de Janeiro] (ZALUAR, 1975, p. 75).

Apesar de tantas mudanças proporcionadas pela fortuna advinda do café e do comércio, em 1860 ainda permaneciam alguns costumes dos tempos coloniais: as mulheres continuavam segregadas do convívio social, como Zaluar (1975, p. 76) observa:

As suas habitações são cômodas, bem mobiliadas, mas falta-lhes ainda esse espírito de sociabilidade que se estabelece pelas relações das famílias, defeito sensível na maior parte das povoações do interior, e que tanto concorre para o seu viver monótono e concentrado. As senhoras raramente aparecem na sala, onde os homens somente recebem as visitas e conversam para entreter o tempo. Estes costumes ir-se-ão perdendo pouco a pouco, como já vão desaparecendo as mantilhas, que apenas figuram hoje para ocultar as rugas de alguma sexagenária matrona, ou são usadas pela gente das classes menos abastadas. As Lorenenses são notáveis pela sua formosura e pelo bom gosto com que se vestem, além da 
sua educação apurada e natural talento. É pena que não animem os salões nem dêem mais vida às reuniões, em que o seu espírito devia ser justamente apreciado.
25. Cf. Evangelista (1978, p. 131).

Mas as transformações estavam em curso, e logo surgem as sociedades literárias, recreativas e dançantes, onde ocorriam memoráveis festas com a participação das famílias lorenenses. E transformações seriam mesmo necessárias para receber condignamente a Princesa Isabel e seu marido, o conde D'Eu, quando, em 1868, em viagem para Aparecida, pernoitaram na cidade, com direito a espetáculo de gala no Teatro de Lorena (RODRIGUES, 1956). Nessa ocasião, "a Camara mandou fazer o carpimento das ruas e largos", e erigir "um arco ou torreão junto à casa de recepção"25 (Figura 22), à maneira dos que se erguiam nas ruas do Rio de Janeiro - costume introduzido no Brasil por Grandjean de Montigny, que concebia os arcos de triunfo para as grandes comemorações

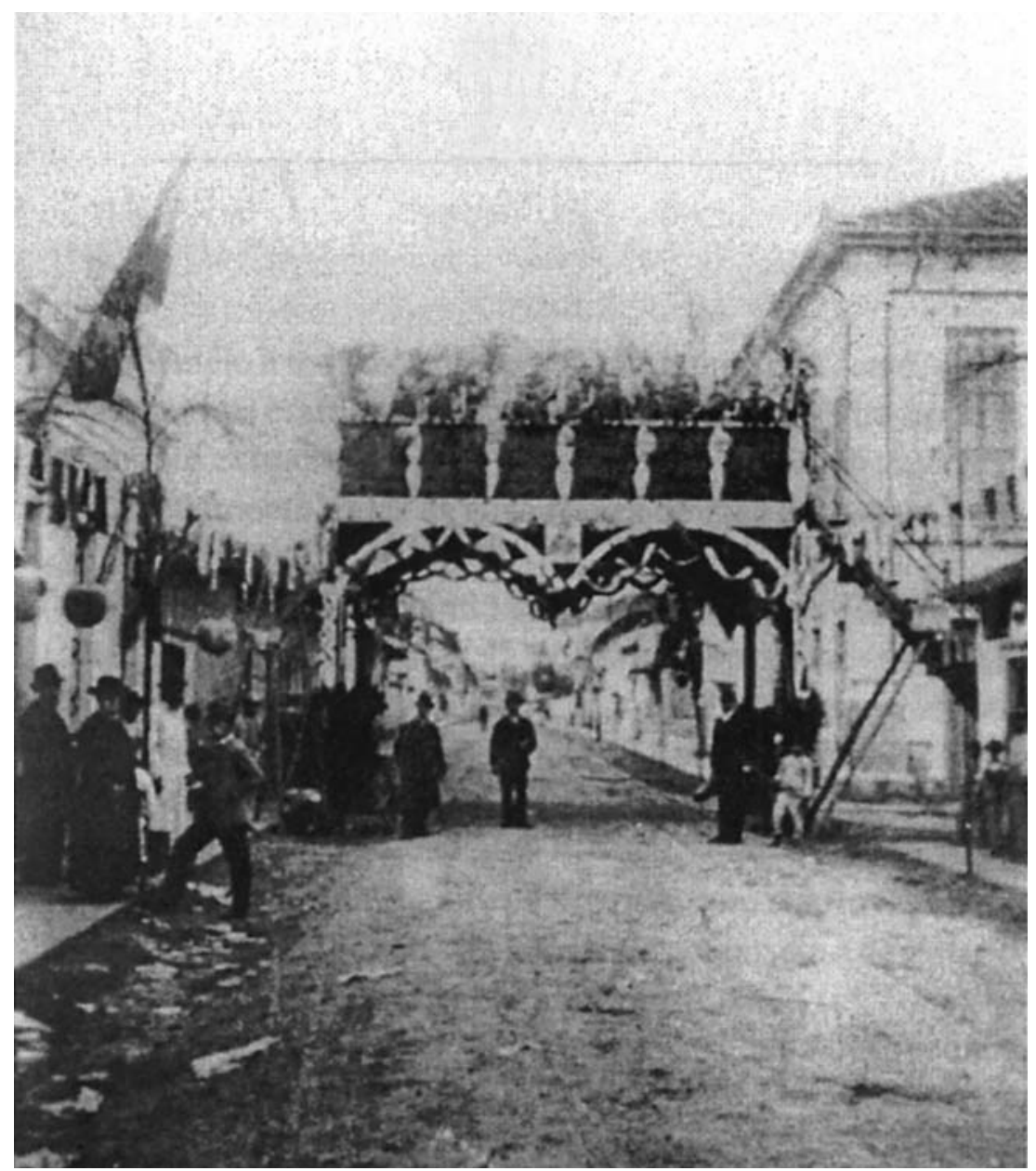

Figura 22 - Arco erigido em homenagem à Princesa Isabel e ao conde D'Eu, em passagem por Lorena. [Sem título], c. 1875, Lorena, SP. Acervo de Ercio Molinari. 
26. Durante seus anos de estudo na École des Beaux-Arts, Grandjean de Montgny foi influenciado por Charles Percier e Pierre Fontaine, os ex poentes da arquitetura francesa na era napoleônica. Ambos foram responsáveis pela criação de um estilo muito próprio, conhecido como Impé rio e, a partir de 1801 , as cenderam à posição de Architectes des palais du premier et deuxième consuls.Para um aprofun damento sobre a formação acadêmica de Montigny, ver Bandeira et al (2003).

27. Ata da Câmara, de 30 de outubro de 1884 . Arquivo Municipal de Lorena. da Corte. Montigny, por sua vez, inspirava-se nos trabalhos de Percier e Fontaine, de quem fora discípulo ${ }^{26}$.

Em 1877, ao estabelecer-se a ligação ferroviária entre o Rio de Janeiro e São Paulo, foi dado "um grande passo no progresso da cidade, e decisivo no seu desenvolvimento" (RODRIGUES, 1956, p. 96), pois, a partir daí, as novidades chegariam mais rapidamente - novas modas, tecidos, livros e literatura, música, mobiliário, materiais de construção e acabamento, enfim, toda uma série de inovações agora estavam a poucas horas de Lorena. A reação é imediata. Por volta de 1879, começam as reformas nos "sobrados apalacetados, com sacadas e lampiões", para transformá-los, ao gosto em voga na corte, em "palacetes neoclássicos, elegantes e sóbrios", como se verá mais adiante, quando do exame do que sucedeu nos principais logradouros lorenenses. A iluminação pública feita com velas de sebo é substituída, em 1871, por lampiões a querosene, que, por sua vez, serão utilizados até 1901, quando se instalam lampiões a álcool. Surgem jornais, novas escolas, uma biblioteca pública.

Este é o início da época de fausto e esplendor de Lorena, cujo auge é alcançado na década seguinte, de 1880, quando a cidade novamente recepcionará a Princesa Imperial e seu marido, em 1884, conforme consta em Ata de 30 de outubro daquele ano ${ }^{27}$. Dois anos mais tarde, em 1886, será o próprio Imperador, acompanhado de D. Tereza Cristina, que se hospedará em Lorena, durante viagem a São Paulo. Os principais espaços públicos da cidade receberão as palmeiras-imperiais a partir de 1884. Por essa época, são feitas as outorgas de títulos à família Castro Lima, como mencionado anteriormente. Fechando esse período, dá-se a construção da nova lgreja Matriz, inaugurada em 1890. Ser ela um projeto de Ramos de Azevedo sinaliza os novos tempos: a emergência da cidade de São Paulo como pólo econômico, a transposição da monocultura cafeeira para o "oeste paulista", a instalação do regime republicano e a consolidação do ecletismo como linguagem arquitetônica preferida da nova burguesia paulista.

As palmeiras e os espaços de representação da elite

O conjunto sobre o qual se debruça este texto constitui-se de três espaços públicos cuja origem remonta à fundação de Lorena, então Freguezia de Guaypacaré. Apesar de cada um deles ter adquirido uma característica única em função de seu significado para a cidade, todos os três recebem tratamento uniforme do ponto de vista estético, de modo a formar, pela sua articulação, uma espécie de eixo ou promenade que se configura como referencial paisagístico de suma importância para Lorena, tanto no aspecto espacial ou formal, quanto no aspecto histórico-cívico (Figuras 23 e 24). Constituem referência "externa", pois estarão, de meados do século XIX em diante, servindo à representação social da elite lorenense, que se organiza a partir da chegada do surto cafeeiro. 


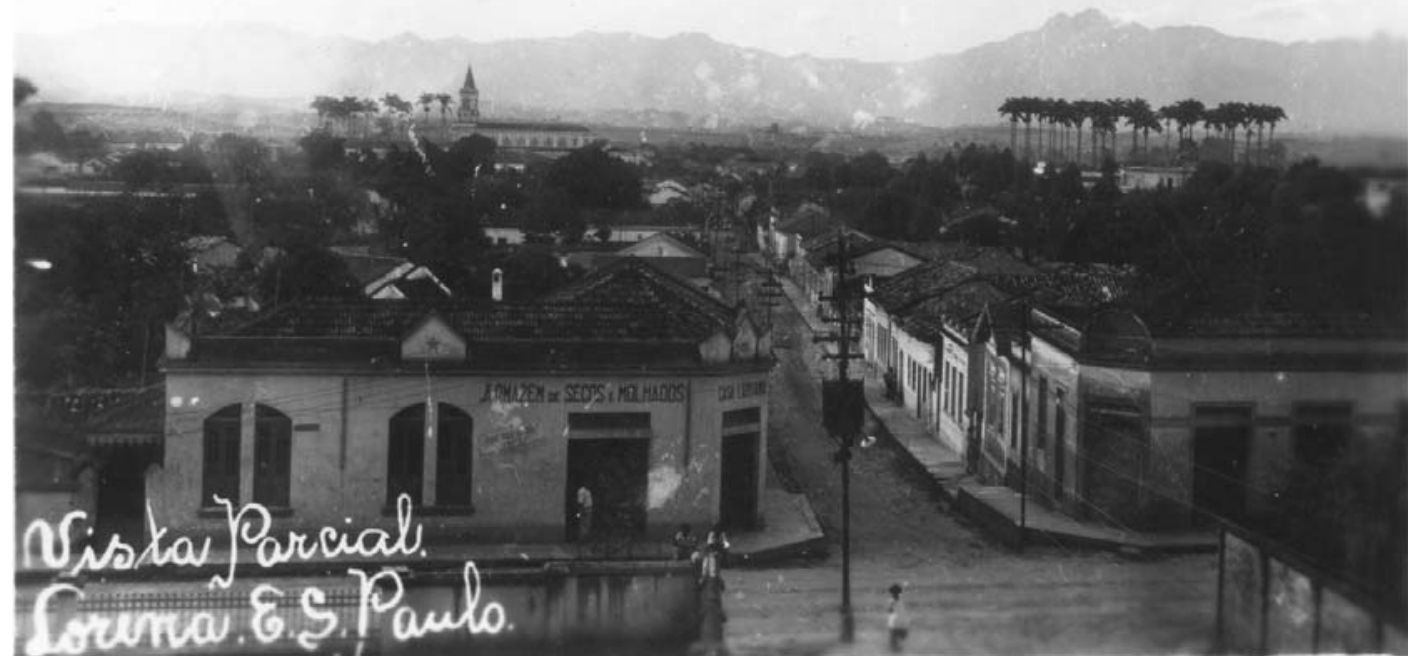

Figura 23 - À direita, conjunto de palmeiras da praça Arnolfo de Azevedo, antigo largo Imperial, no centro, conjunto de palmeiras junto à Matriz de N. S. da Piedade e, na extrema esquerda, trecho do conjunto de palmeiras da rua da Viscondessa, atual rua Cons. Rodrigues Alves. Lorena. Vista parcial. Fotografia, c. 1940, Lorena, SP. 13 × 8,7cm. Acervo da autora.

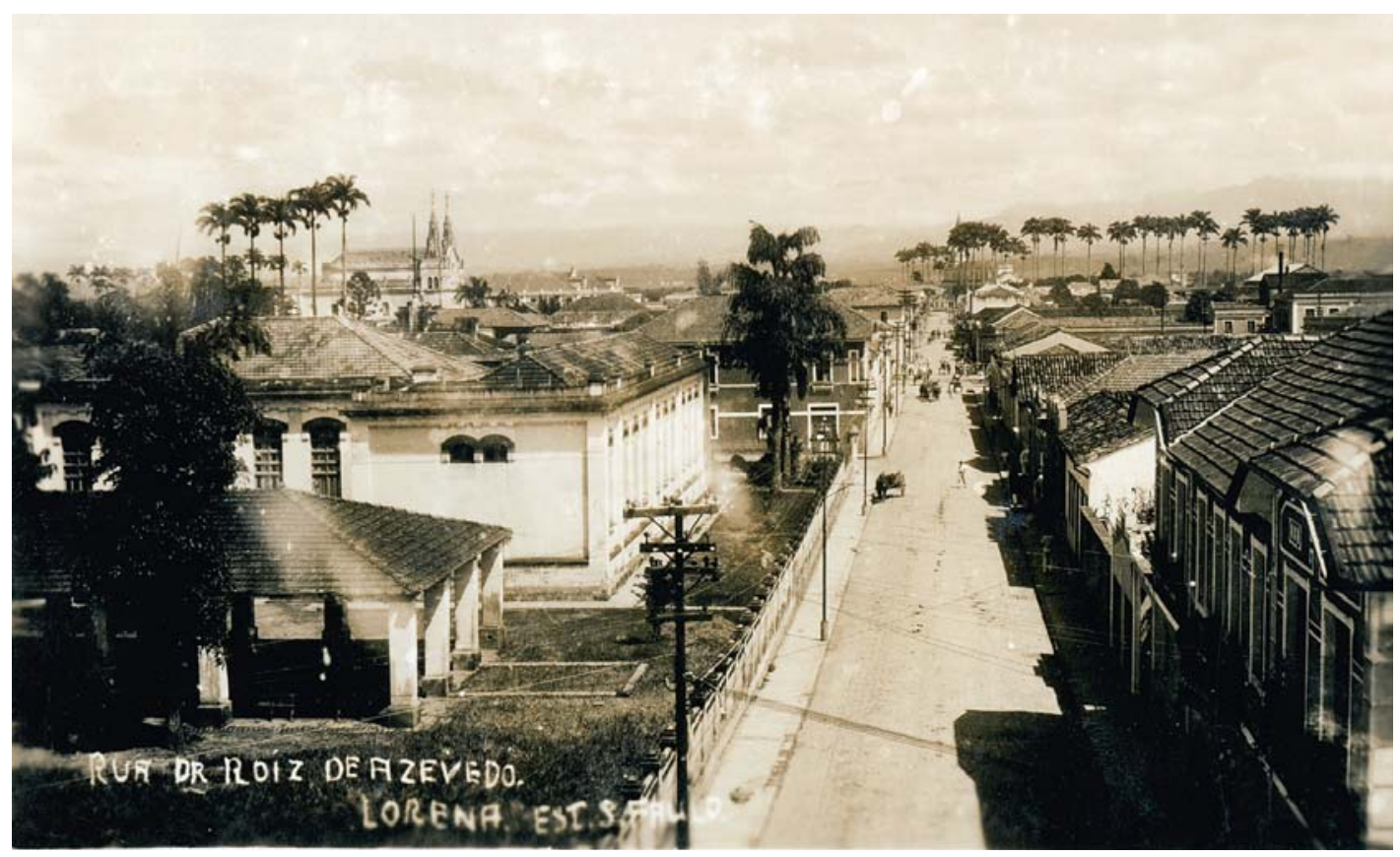

Figura 24 - Rua Dr. Roiz de Azevedo. Fotografia, s.d., Lorena, SP. Acervo do Museu Paulista da Universidade de São Paulo. 
28. Ata da Câmara, de janeiro de $1884,23^{\text {a }}$ Sessão ordinária.Arquivo Municipal de Lorena.

29. Sobre as diferentes técnicas construtivas e sua interação no Vale do Paraíba paulista, ver D'Elboux (2004).

30.A esse respeito, ver Le$\operatorname{mos}(1999)$
Euclides da Cunha, em carta enviada a Coelho Neto em 1903, referese às palmeiras de uma maneira em que fica implícito que as reconhece como símbolo de Lorena, ao compará-las às roseiras da cidade do amigo: "O vento sul que ahi está destoucando as roseiras de Campinas, sacode neste momento as palmeiras imperiaes da minha melancholica Lorena" (CORRESPONDÊNCIA..., 1963, p. 186-187).

Apesar de seus logradouros ainda abrigarem as festas das quais toda a coletividade participa, eles são, de fato, palco para as aparições sociais da elite, tanto para a população lorenense quanto para os ilustres visitantes que, desde então, são acolhidos pelo baronato. Assim,

no último quartel do século XIX, a preocupação maior da municipalidade e dos beneméritos é o embelezamento da cidade. [...] Aformoseamento, embelezamento, melhoramento são as palavras mais encontradiças nos ofícios e atas desse período [1 875-1900] (EVANGELISTA, 1978, p. 130).

Em janeiro de 1884, por exemplo, Teophilo Braga expressa justamente essa preocupação, ao solicitar

que para embellesamento da praça do Barão de Moreira Lima se mande levantar um coreto na mesma praça [e (mais adiante)] que se mande fazer o calçamento da praça do Barão de Moreira Lima, entre a lgreja de S. Benedicto e a Igreja da Misericórdia digo a Casa da Misericordia, devendo o calçamento cazo possivel ser feito de pedra natural segundo a bitola da Comarca ${ }^{28}$,

o que também traduz o esforço de regularização dos logradouros lorenenses.

No âmbito do presente trabalho, a importância de tais logradouros reside no fato de abrigarem algumas das primeiras manifestações de caráter neoclássico no ambiente urbano de Lorena, pois, para o seu teatro social, a elite necessitava de um palco à sua altura, equiparado ao que de melhor se estivesse produzindo no Rio de Janeiro ou na Europa. Retomando a idéia de que o Neoclássico acompanhou o café na subida da serra desde as terras fluminenses, seria natural que por aqui também houvesse manifestações desse estilo.

No entanto, como já dito, nas partes fluminense e paulista do Vale do Paraíba, o café causou impactos de diferentes proporções. Até por conta das distintas técnicas construtivas praticadas lá e cá, houve a necessidade de certas adaptações $^{29}$ e o Neoclássico, semeado no Rio de Janeiro por Montigny, floresce no Vale paulista bastante modificado e empobrecido ${ }^{30}$. Mas nem tanto que não pudesse ser utilizado nas reformas dos palacetes coloniais da cidade, mudando-the os ares, renovando-thes o viço.

É também "a época em que as primeiras palmeiras-imperiais são plantadas, e depois replantadas, inicialmente na rua Viscondessa de Castro Lima (1884), e posteriormente no Largo da Matriz [e] no Largo Imperial" (EVANGELISTA, 1978, p. 154). As mudas foram trazidas do Rio de Janeiro, como atesta a Ata da Câmara, de 22 de fevereiro de 1884: 
Assim mais comunicou que tendo sido remetidas pelo Snr J. J. Anto. Braga as palmeirasimperiais da Corte, com frete da quantia de 73- a pagar n'esta cidade, autorisou o Snr. Procurador a retira-las na estação fazendo o respectivo pagamento e pedia approvação desta Camara ${ }^{31}$.

Os espaços em questão são: o largo Imperial, atual praça Arnolfo de Azevedo; o largo da Matriz, atual praça Baronesa de Santa Eulália e o eixo formado pelas ruas Viscondessa de Castro Lima e Direita, hoje unificadas sob o nome de rua Conselheiro Rodrigues Alves, que uniam o largo da Matriz diretamente ao Cemitério Municipal e à saída para Guaratinguetá, pela Estrada Geral (Figura 25). A uni-las, a ponte do Faustino, em madeira, substituída, em
31. Ata da Câmara, de 22 de fevereiro de $1884,3^{\mathrm{a}}$ Sessão ordinária.Arquivo Municipal de Lorena.

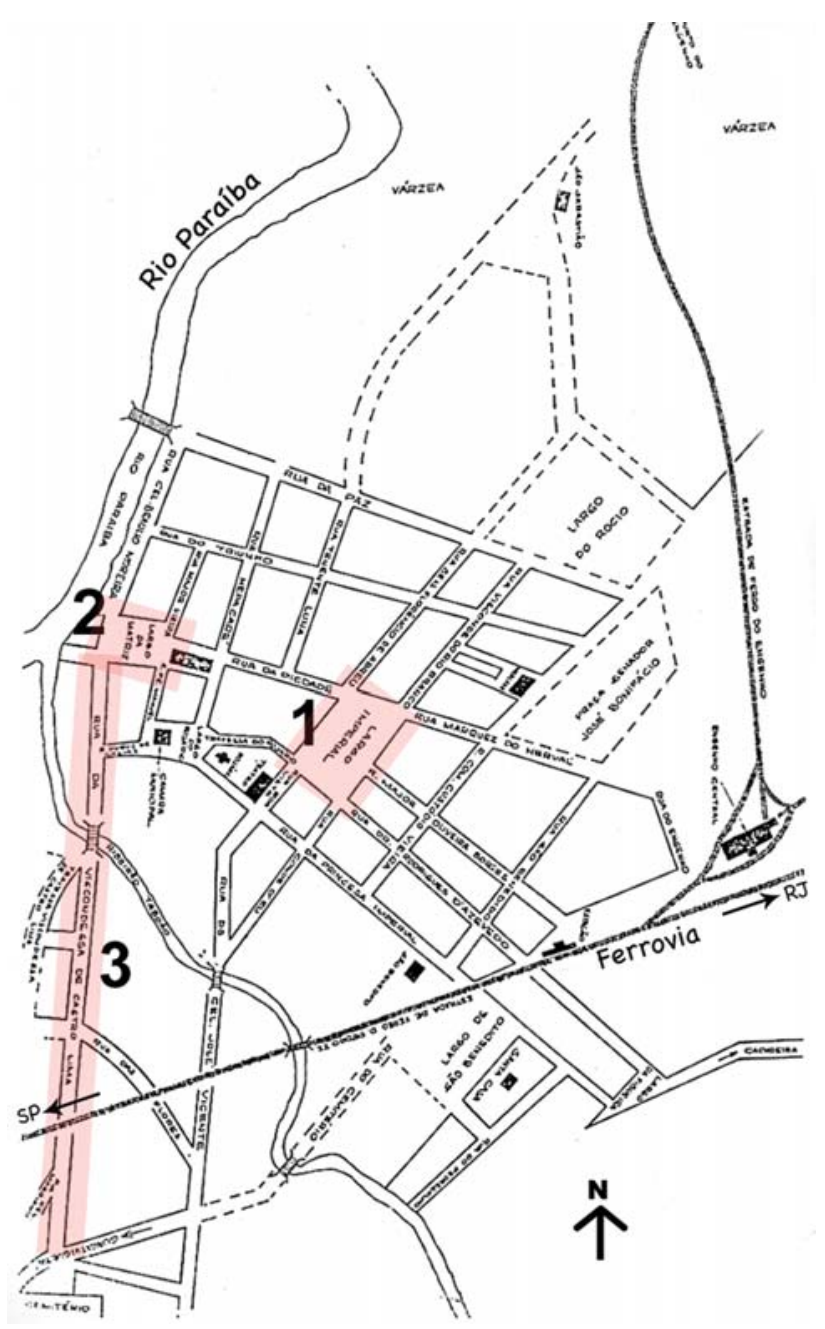

Figura 25 - Localização do largo Imperial (1), largo da Matriz (2) e rua Viscondessa de Castro Lima (3) sobre ilustração constante em Lorena no século XIX (EVANGELISTA, 1978, s. n. p.). 
1889, por uma ponte metálica (Figura 26) que o presidente da Província, o lorenense Pedro Vicente de Azevedo, encomenda na Bélgica (BARRETO, 1998).

Largo Imperial

Por muito tempo, o largo Imperial foi um descampado onde dormiam varas de porcos, gado, tropeiros com seus muares em passagem pela vila. Algumas vezes foi utilizado para enforcamentos. Zaluar (1975, p. 74), em 1860, assim o descreve: "Há em Lorena três grandes praças: a da Matriz, a

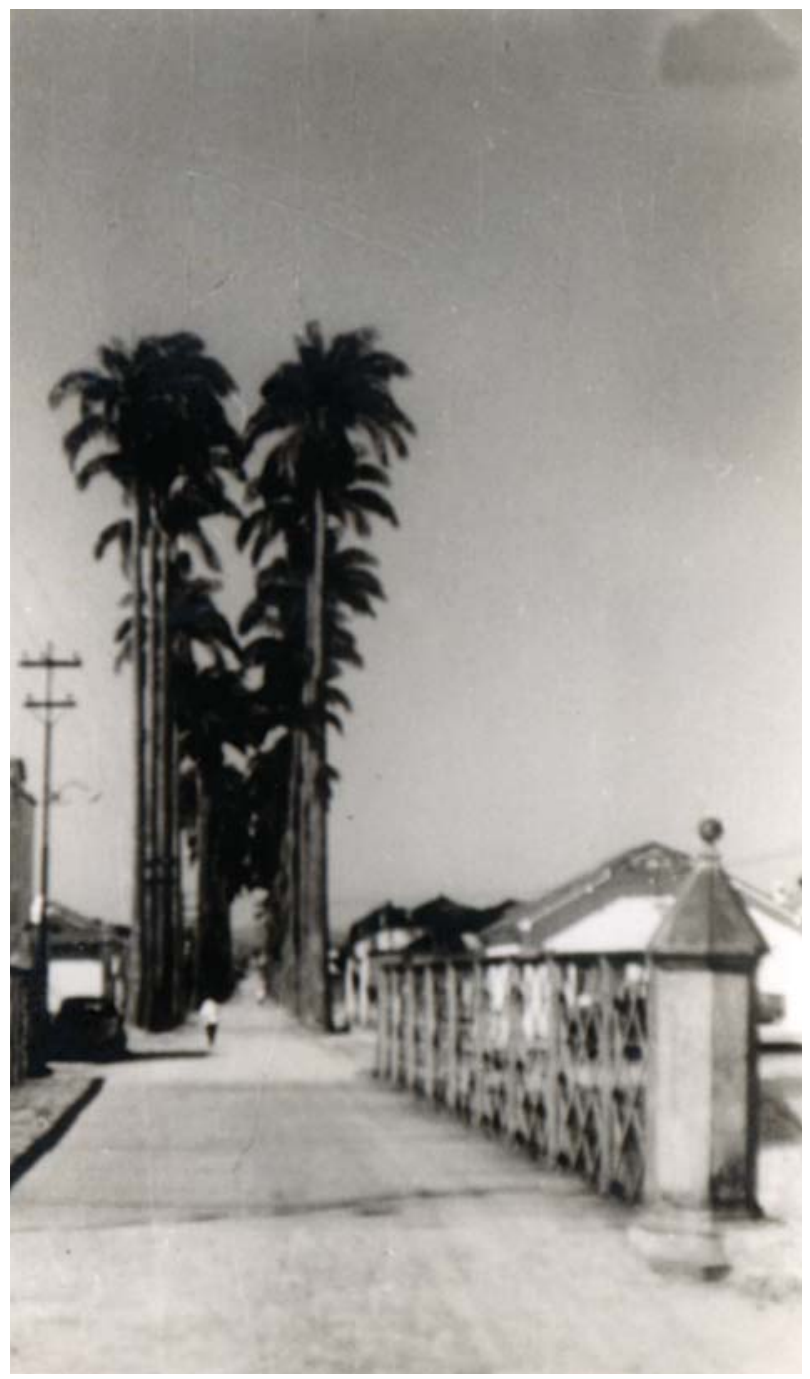

Figura 26 - Rua das Palmeiras e ponte metálica. Fotografia c. 1940, Lorena, SP. 7,8 × 13,1 cm. Acervo da autora. 
do Rosário, onde existe uma igreja com esta invocação, e finalmente a praça Imperial, que é muito grande, bem quadrada e plana".

Serviu também para a realização de festas populares, quando, a partir de meados da década de 1860, a vida social e cultural da cidade floresce. "As festas de rua estavam sempre relacionadas com a lgreja, predominando as Cavalhadas da Festa do Divino, realizadas em 1865, por exemplo, no Largo Imperial" (EVANGELISTA, 1978, p. 130). A primeira iniciativa para a arborização desse largo deu-se nesse mesmo ano: "o Largo Imperial, por sua grande área, constituía um encargo pesado para a municipalidade, até que se resolveu arborizá-lo, deixando espaço central para um futuro chafariz" (EVANGELISTA, 1978, p. 1111 , que chegou a ser construído, mas nunca funcionou, sendo demolido na década seguinte. $\bigcirc$ largo recebeu iluminação em 1885 e teve suas palmeiras plantadas em 1884, "por ordem do Comendador Arlindo Braga, quando Presidente da Câmara" (CESAR, 1928, p. 73).

Por iniciativa do barão da Bocaina, "em 1887 [...], foi autorizado seu ajardinamento, segundo planta graciosa do eng. Anselmo Gunther e auxílio dos moradores do Largo, sendo contratado Giuseppe Girardelli e depois Constantino Balduino, italianos, para o serviço" (EVANGELISTA, 2001 , p. 116 ). $\bigcirc$ relatório da Comissão encarregada de gerir e administrar os trabalhos de ajardinamento do largo registra que, "depois de terem empregado todos os meios no seo alcance para desempenho de tão ardua tarefa [...] para o fiel desempenho da planta que thes foi apresentada", faltava ainda regularizar os canteiros e "fazer a plantação de arvores e grama", o que poderia "importar em 300 hrs" $^{\prime \prime 2}$.

As obras se estenderam até 1890, quando finalmente foi inaugurado (CESAR, 1928). "Além do gramado, foram plantadas mais 50 palmeiras-imperiais e outras árvores, por doação do Ministério da Agricultura, e solicitou-se à Província - auxílio de 600\$000 que prometera" (EVANGELISTA, 1978, p. 157). Complementando o projeto, havia

rosas trepadeiras em toda a sua volta, as duas ruas e o largo apedregulhados onde estariam dois bancos de madeira com pés de ferro, as casuarinas e o coreto para as retretas dominicais. Até um guarda deveria permanecer todas as noites, domingos e dias santos, que parece não ter adiantado muito, pois em 1900 foi cercado por um gradil e portões de ferro, que fechavam às 22 horas $^{33}$ (EVANGELISTA, 2001, p. 116 ).

A descrição acima pressupõe um projeto cuja inspiração paisagista estava de acordo com o que se produzia no Rio de Janeiro, principalmente nos projetos a cargo de Glaziou, que nos trouxe o gosto pelo jardin anglais, e concomitantemente, contribuições de cunho eclético, já tão difundido na Europa à essa época, como assinala Azevedo ${ }^{34}$ (apud DEL BRENNA, 1987, p. 32):

Quando, em 1861, o botânico francês Auguste François Marie Glaziou é chamado a realizar a reforma do Passeio Público - que perderá assim as suas originais feições "pré-românticas", obras de Mestre Valentim - entre os novos elementos arquitetônicos e decorativos introduzidos no novo desenho "à inglesa" do parque estão um "botequim de arquitetura grega" precedido
32. Ata da Câmara, de 17 de setembro de 1888. Arquivo Municipal de Lorena.

33. A descrição da Praça Imperial é muito semelhante à descrição das praças produzidas pela reforma de Haussmann: "Ces squares, entourés de grilles à l'exception du square Victor, présentaient pour la plupart l'aspect de jardins paysagers, avec une ou plusiers pelouses ornées de massifs, autour desquelles serpentaient les allées. Certains ne possédaient qu'une fontaine, D'autres avaient une pièce d'eau à laquelle parfois s'ajoutait un ruisseau artificiel, tombant en cascade d'un rocher" (HUGUENEY, 1954, p. 109).

34 .Ver Azevedo (s. d.). 
35."Le nom de square sig nifie, en anglais: carré Nous désignons ainsi, à l'instar de nos voisins d'outre-mer, les jardins presque toujours clos de grilles, entourant ou côtoyant certains de nos édifices, occupant le milieu de la plupart de nos Places, ou bien utilisant des espaces laissés libres par le tracé de nos voies publiques nouvelles et par le plan de lotissement des parcelles de terrain demeurées en dehors des alignements de ces voies et livrés à la reconstruction. La forme de ces enclos verdoyants et fleuris dans la belle saison, pleins d'air et de lumière, en tout temps, ne justifie point cette qualifications, je le confesse, en bien de cas." (HAUSSMANN, 2000, p. 933).

36.Ata da Câmara, de 5 de novembro de 1888,18 . Sessão. Arquivo Municipal de Lorena. por "quatro colunas de ferro de ordem corinthia" e ladeado por um coreto, "onde todas as noites toca uma banda de música alemã"; um "pavilhão rústico no centro do qual vê-se um vaso à Luís XV com flores e frutos de ferro fundido", um "lindo ribeiro" atravessado por uma ponte de madeira rústica e outra de ferro, e enfim um "chalet suíço" com um "peristilo sustentado por colunas de madeira", destinado à moradia do próprio Glaziou, diretor do jardim.

Embora a instalação de um gradil suscite a idéia de problemas com relação à segurança pública, acreditamos que sua existência estivesse mais ligada à moda vigente de então, posto que os principais jardins da Corte eram cercados, à exemplo das squares ${ }^{35}$ de Haussmann em Paris (Figuras 27 e 28). E talvez não tivessem sido colocados antes por falta de recursos da municipalidade, pois, a partir da Proclamação da República, aos poucos o baronato deixa de aplicar seus recursos diretamente nos espaços públicos da cidade ou em melhorias urbanas. Sua influência será mais discreta a partir de então. Já em fins de 1888, é solicitada à Câmara que "officie ao Exmo Ministro da Agricultura pedindo a graça de fornecer gratuitamente 70 plantas de diferentes espécies, para o jardim publico d'esta cidade, bem como o transporte das mesmas" 36 .

As palmeiras são plantadas no perímetro da praça (Figura 29), conformando, com a área interna da mesma, uma espécie de átrio, de modo um pouco diverso do plantio em colunata, consagrado pelas primeiras experiências no Jardim Botânico do Rio de Janeiro e utilizada no largo da Matriz e na rua da Viscondessa. Se o seu interior é pitoresco, esse anel envoltório é

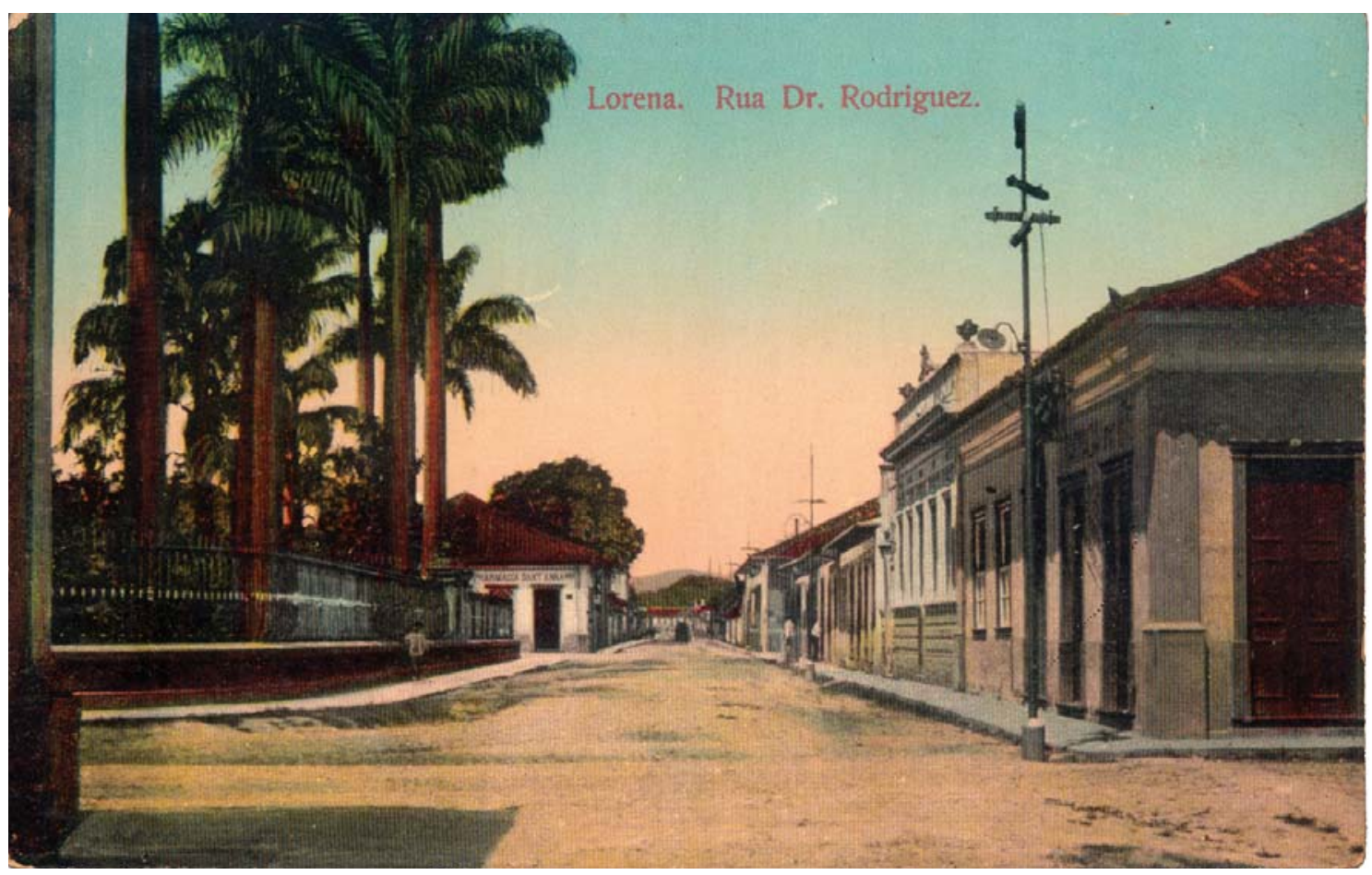

Figura 27 - Lorena. Rua Dr. Rodriguez. Cartão postal, c. 1915, Lorena, SP. Acervo da autora. 


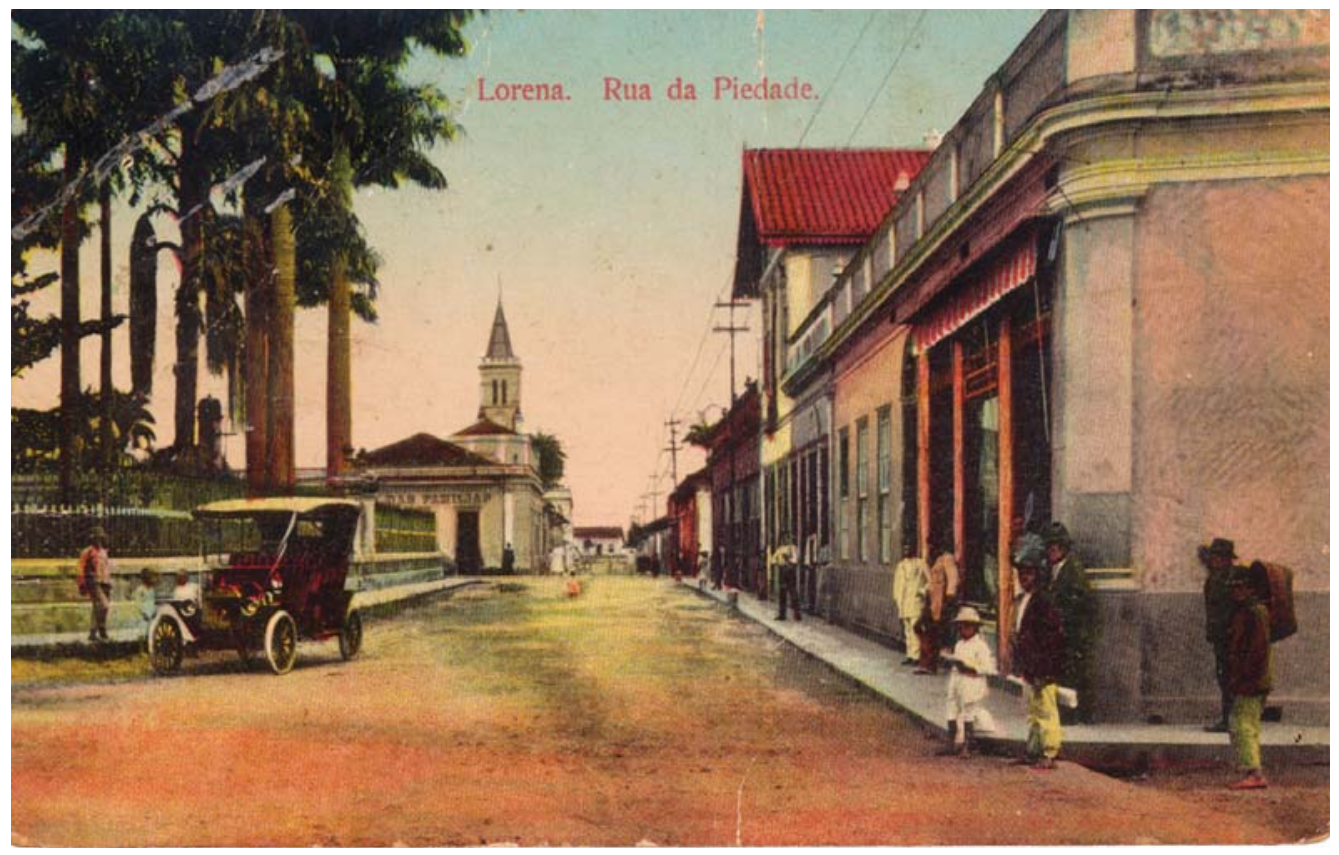

Figura 28 - A rua da Piedade ligava o Largo Imperial (atual praça dr. Arnolfo de Azevedo) ao largo da Matriz. Lorena. Rua da Piedade. Cartão postal, c. 1915, Lorena, SP. Acervo da autora.

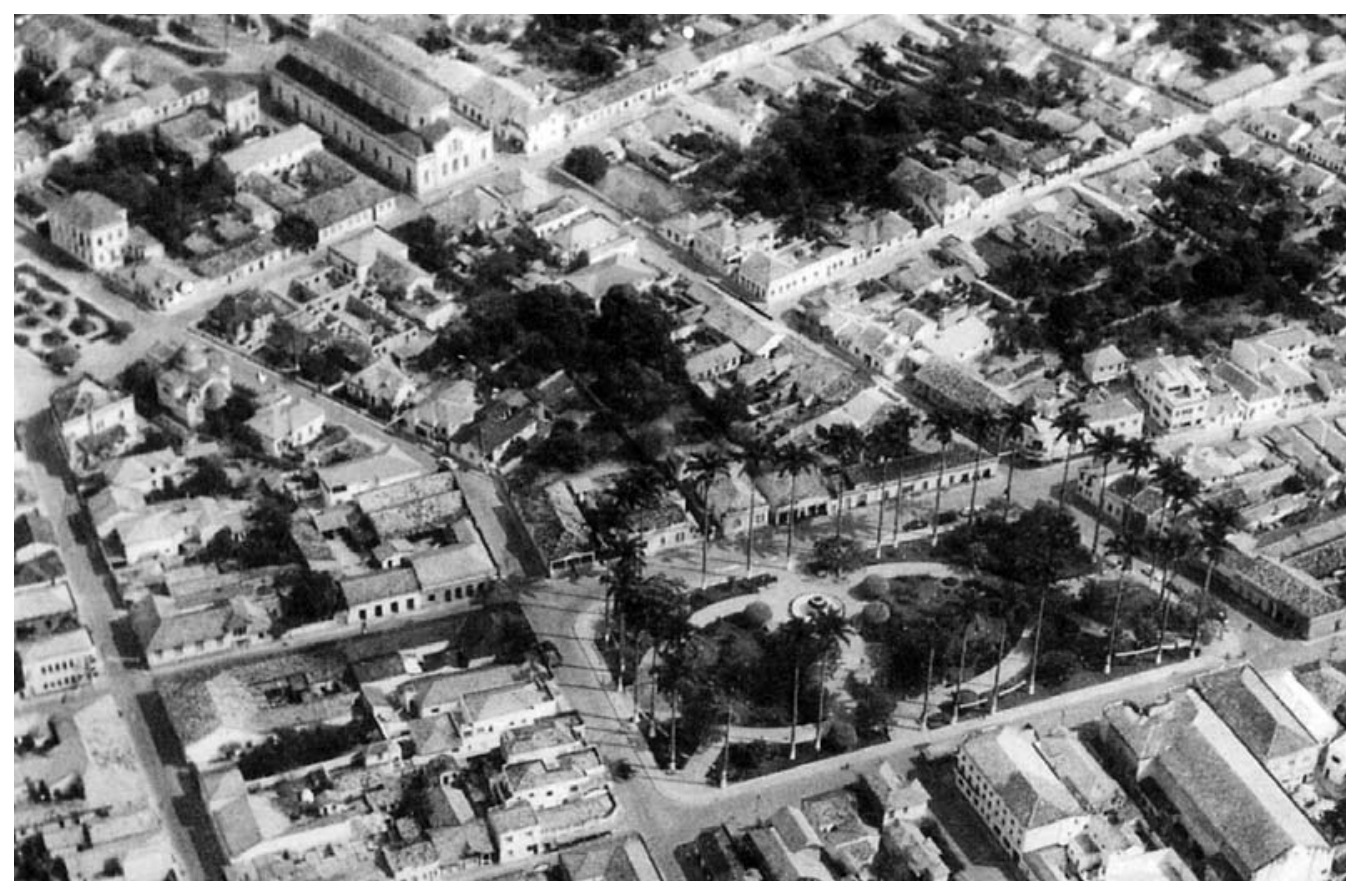

Figura 29 - Nesta foto é possível observar o desenho da praça, de inspiração paisagista, com as palmeiras à sua volta. Acima, a lgreja Matriz, à esquerda, a lgreja do Rosário. Vista aérea do centro de Lorena, c. 1965, Lorena, SP. Fotografia. Acervo de Ercio Molinari. 
sua antítese, buscando um efeito grandiloqüente, pela escala das palmeiras frente ao casario que circundava a praça, e mesmo na relação estabelecida com o seu desenho interno.

Largo da Matriz

É o núcleo inicial da cidade e - depois que o tráfego de tropeiros foi desviado, com a construção da ponte sobre o Paraíba - é também o local escolhido pela elite para estabelecer moradia. $\bigcirc$ rio fechava-the o lado oriental e, no lado oposto, estava a Matriz. Mais tarde, Zaluar (1975, p. 74) a descreve como "uma vasta praça em frente ao Paraíba". O registro feito por Julien Pallière em 1821 mostra a igreja isolada do casario, o que não corresponde ao relato de Saint-Hilaire, de março de 1822: "A igreja paroquial forma um dos lados da pequena praça quadrada" (SAINT-HILAIRE, 1974, p. 71). A descrição do viajante francês é comprovada pelos ofícios expedidos à municipalidade solicitando a abertura de um beco ao lado da igreja, como poderá ser visto adiante.

Entre 1820 e 1830, já haviam se instalado no largo da Matriz e imediações alguns proprietários, em "sobrados apalacetados, com grandes e numerosas sacadas características das casas ricas da época, como nenhum mais existe em Lorena, mas ainda encontradiços em Bananal, S. Luiz do Paraitinga, e outras velhas cidades paulistas, e freqüentes nas do interior de Minas" (RODRIGUES, 1956, p. 55) e, portanto, de acordo com a arquitetura colonial tradicional. Curiosa prova da valorização do logradouro é o pedido que o pai do conde de Moreira Lima, Joaquim José Moreira Lima, faz à Câmara Municipal, no sentido de obter uma data de terras junto à Matriz, em 1831 , conforme pode observar-se do exame da transcrição a seguir, onde o suplicante, mostrando suas habilidades para os negócios, solicita para si a doação de área pública:

Diz Joaquim José Moreira Lima, desta Villa e nella Negociante, casado e com pronostico de grande família, segundo o princípio dela, que acha-se totalmente desarranchado e por isso fez cumpra no Beco do Porto de hum pequeno terreno, que não lhe é bastante para edificar húa propriedade suficiente, o que praticou com o destino de implorar de Vv. Ssas. No dito beco de des palmos de frente, visto que elle tem uma exurbitante largura, e aquella pequena diferença dos des palmos em nada prejudica, nem ao Publico e nem a este Municipio (apud RODRIGUES, 1956, p. 55-56).

E, a seguir, sugere à Câmara a instalação da 'quitanda' - que desvalorizaria seu empreendimento conseguido às custas da municipalidade nos fundos do edifício da Cadeia, como "o é em outras vilas":

[...] mas agora chegou ao conhecimento do Supp. E que V. V. S. Sas. deliberarão aquele Beco para quitanda; porem V.V.S.S.as. hão de desculpar ao Supp.e., que com o mais profundo respeito passa a apresentar as insuficiencias do lugar para o Ramo destinado: 
1․ Que naquelle lugar e na visinhança só existem familias honestas, honradas, e todas pessoas de Bem, e a quitanda he a base e Orgão de pessoas rasteiras, barulhos, e discordias, conversações deshonestas eindecorosas, dezatinos e absurdos improprios de familias, bebedeiras de todos os que se impregão neste vicio, e o maior que o Supp.e. calla por modestia.

$2^{\circ}$ Hé hum terreno muito pequeno para o fim projectado, e [...] visto que em outras Villas he de uso antigo ser a quitanda no Patio da Cadeia, queiram V.V.S.S.as. annuir a si a presente representação e haver por bem remover a dita quitanda para o dito Patio, e deferir a Supplica do Supp.e. visto a sua urgente necessidade daquelles des palmos de terreno, e de muito justas causas que o Supp.e. representa a $V_{V}$. S.S. as. de quem espera R.M.cê lapud RODRIGUES, 1956, p. 55-56).

Da leitura da transcrição do documento, pode depreender-se que o largo da Matriz já se encontrava em franco processo de valorização, ainda mais que a solicitação foi aceita pela Câmara, "contanto que deixe o mesmo [beco] com largura de 35 palmos" ${ }^{\prime 37}$. Saíam os porcos e mulas, e chegava a elite abastada, de modos afrancesados. Dessa mesma época, era o palacete construído por João Batista de Azevedo (e mais tarde adquirido pelo Comendador Bráulio Moreira de Castro Lima), sendo, como o de seu pai, Joaquim José de Moreira Lima, construído em taipa de pilão (RODRIGUES, 1956). Já havia, na vila, cerca de 300 casas e os principais edifícios públicos eram a Casa da Câmara e a Matriz.

Por volta de 1838, a Câmara Municipal decide demolir a velha Igreja Matriz, erguida por volta de 1720 e que se apresentava em ruínas, para erigir novo templo. Para tanto, a Câmara pediu à Assembléia Legislativa Provincial verba de dois contos de réis. No mesmo ano, o prédio da Cadeia e Câmara foi "encascado, rebocado e branqueado" e deu-se início à construção do cemitério, posto que foram proibidos os sepultamentos nas igrejas (EVANGELSTA, 1978). A igreja de então, apesar de Matriz da vila, deveria ser, portanto, muito simples e desprovida de qualquer atrativo, pois Saint-Hilaire (1974, p. 71) nada informa a seu respeito, citando, inclusive, que a única igreja que visitou na cidade foi a do Rosário, cuja ornamentação interna não o agradou: "Em outra praça irregular e ainda menor que a primeira, fica a segunda igreja, dedicada à Nossa Senhora do Rosário. Esta foi a única que visitei".

A segunda lgreja Matriz, cuja construção foi iniciada em 1838 no mesmo local da anterior, ainda não estava totalmente acabada e já apresentava problemas, com a ameaça de desabamento do telhado. As obras eram lentas. Em 1854 foi solicitada à Câmara a abertura do terreno ao lado da igreja, para que se pudesse "beneficiar" as suas taipas. Cinco anos mais tarde, em 1861, foi feita nova solicitação, pois o beco ainda era necessário "para a colocação de andaimes do prédio em construção". Era uma necessidade técnica que repercutiu no desenho urbano, pois, aberto o beco - e tendo sido separada a igreja das casas vizinhas -, o aspecto do largo transformou-se em definitivo, perdendo sua configuração inicial, estabelecida nas primeiras décadas do século XVIII (EVANGELISTA, 1978). 
38. O Paraíba, como todo rio de planície, estava sujeito a mudanças de seu leito principal, assim como dos meandros e braços. Foi o que ocorreu na década de 1880 , quando, após o período de cheia abandona o seu leito original, transferindo-se mais para oeste, restando uma extensa várzea que só será ocupada a partir de meados do século XX A cidade, que havia nascido às suas margens, em posição privilegiada em relação ao sítio natural, perde sua principal referência histórica e paisagística.

39.Tombado pelo Condephaat (Processo $\mathrm{n}^{\circ}$ 00526/75, Tomb. Res. de 10 out. 1975 , D. O. de 11 out. 1975).
Segundo o mesmo autor, havia vários becos ao redor da praça da Matriz, que foram sendo fechados por sua incorporação aos lotes, ou mudados de lugar, também para a comodidade dos proprietários de terrenos lindeiros à praça. Este foi o caso do beco que dava acesso ao porto do rio, que, aos poucos, foi sendo deslocado para a esquerda de sua posição original, acabando por ficar em frente ao casarão levantado por João Batista de Azevedo. "Ali foram plantadas duas palmeiras-imperiais, além de uma linda paineira, que existiam até bem pouco tempo e estavam perdidas, pois não havia mais porto, nem rio", que se afastou da praça no final do século XIX38 (Figuras 30 e 31 1). "O último beco desapareceu em 1884, quando o Dr. Rodrigues de Azevedo, depois Barão de Santa Eulália, fez doação de terreno", junto ao seu solar (EVANGELISTA, 2001, passim).

Quanto ao palacete Moreira Lima, começou a ser construído em $1852^{39}$

Herdando muitas das características árabes, suas janelas amplas, suas arcadas, seu pátio interno, onde existia um repuxo, está a desafiar o tempo e a mostrar sua perfeita adequação ao meio. Na verdade, tratava-se do estilo neoclássico, com numerosas adaptações. Mais tarde será reformado e esmeradamente mobiliado (EVANGELISTA, 1978, p. 115).

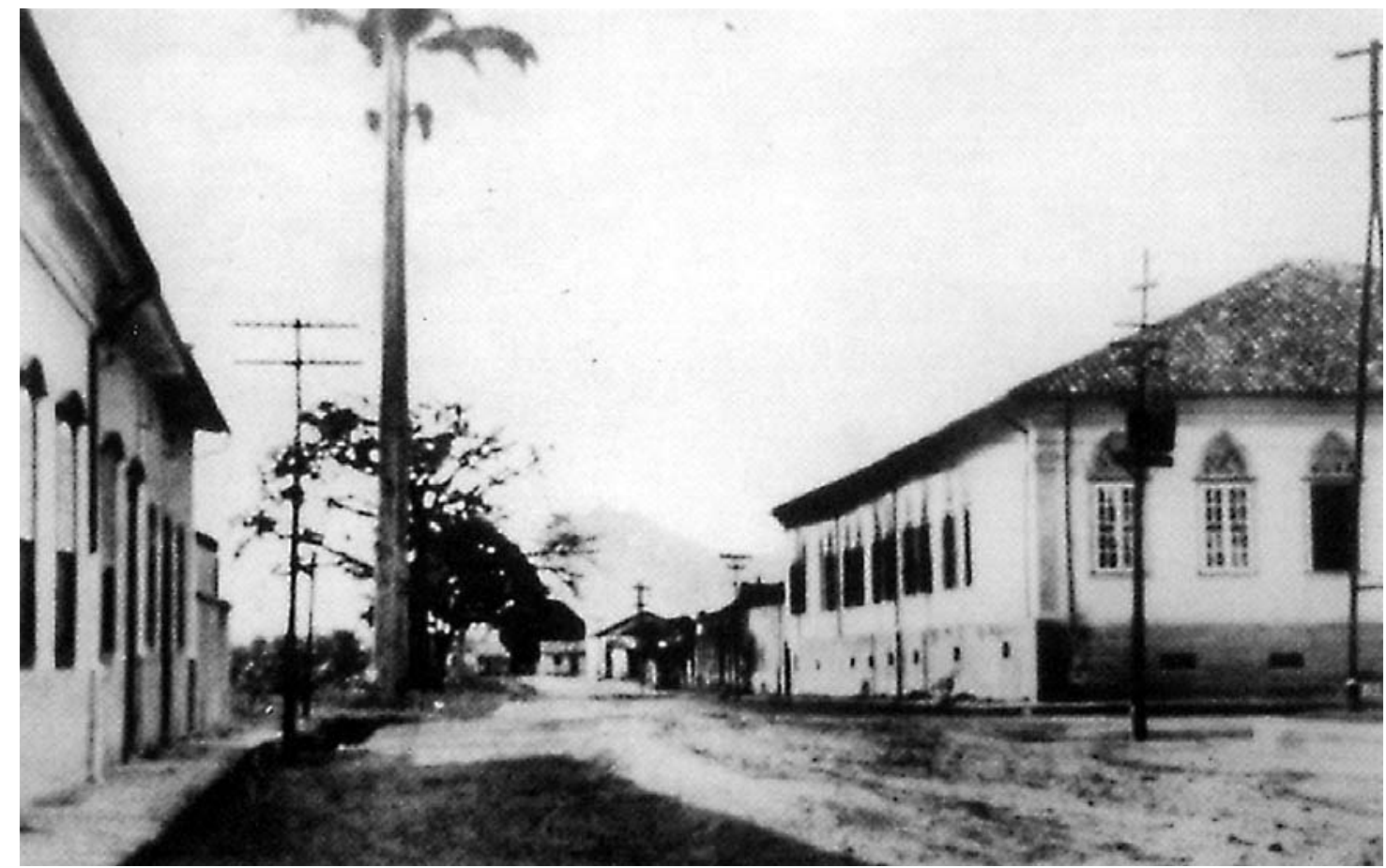

Figura 30 - Palmeiras imperiais plantadas no beco que dava acesso ao antigo Porto do Meira, em frente à residência de João Batista de Azevedo, depois adquirida pelo comendador Bráulio de Castro Lima. Fotografia c. 1930, Lorena, SP. Acervo Ercio Molinari. 


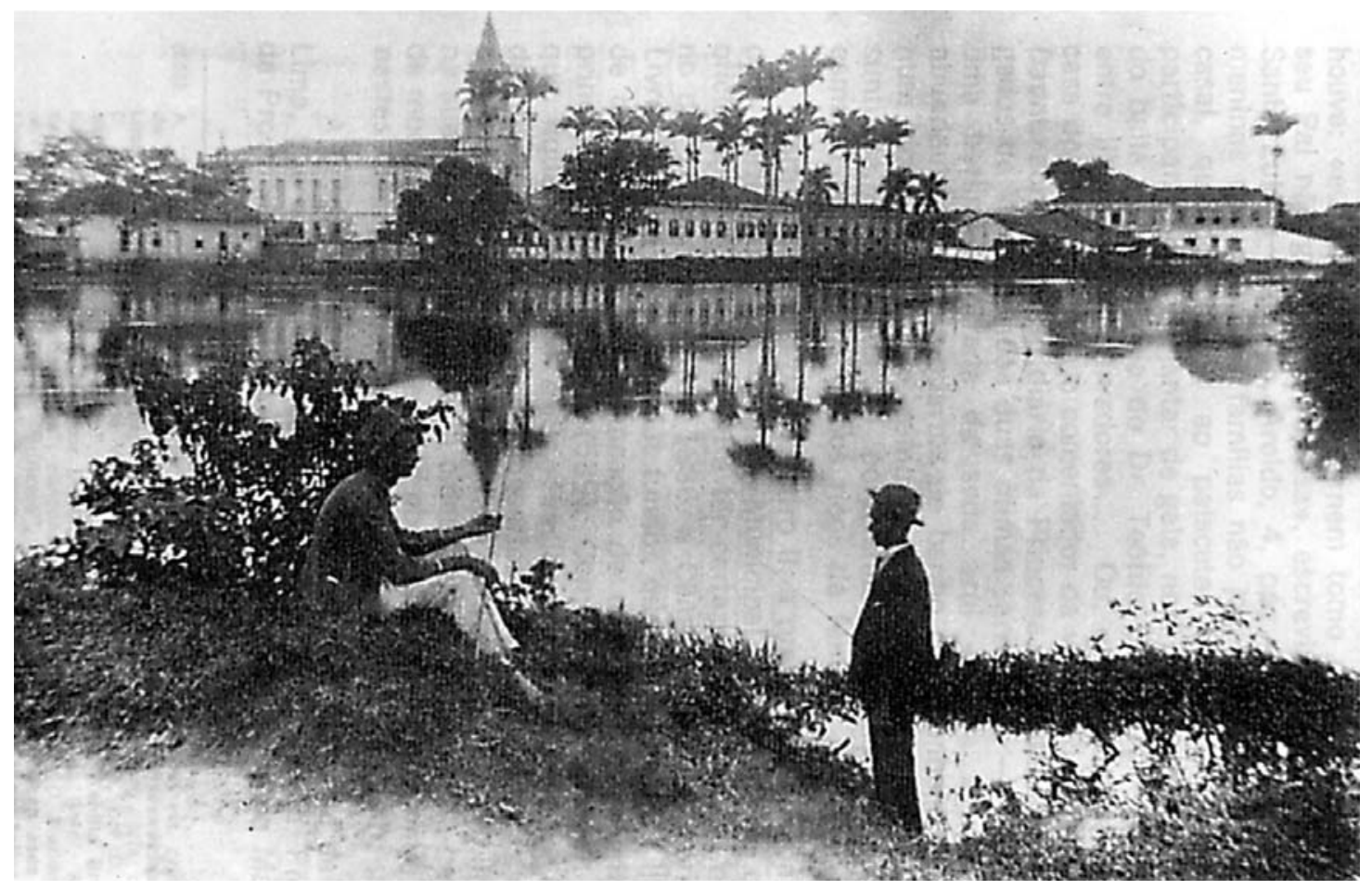

Figura 31 - À direita da Matriz, em meio às palmeiras, está a casa do comendador Bráulio de Castro Lima. A casa assobradada mais à direita é a residência do conde de Moreira Lima. O conjunto de palmeiras é o marco do largo da Matriz, onde o baronato se instalou. Até o fim do século XIX, o rio Paraíba passava próximo ao largo da Matriz. Fotografia, c. 1930, Lorena, SP. Acervo de Ercio Molinari.

Neoclássico a que o autor se refere não é propriamente aquele que se produziu no Rio de Janeiro, quer na obra do próprio Grandjean de Montigny, quer pelas mãos da geração formada na Academia de Belas-Artes, sob a orientação desse mesmo arquiteto. Como já dito no início deste texto, o estilo - se é que se pode falar assim - que subiu a serra desde a Corte, em direção às terras paulistas, é uma linguagem feita de adaptações, principalmente em função das limitações técnicas locais.

No começo do café, a arquitetura das casas ricas urbanas foi aquela ainda comprometida com as soluções pombalinas aliadas a critérios de composição próprios do neoclássico trazido pela Missão Francesa. Foi uma fatal aliança de estilos por acaso possibilitada pelos precários recursos técnico-construtivos ainda vigentes, pois a taipa de pilão, com suas limitações, não permitia devaneios arquitetônicos, nada além daquilo que sabiam e estavam a fazer (LEMOS, 1999, p. 184).

A sintaxe dessa linguagem era bem restrita, baseada na simplificação de motivos originais franceses ou mesmo fluminenses.

A arquitetura de taipa bem que tentou conviver com o neoclássico trazido pela Missão Francesa instalada na Corte por Dom João VI. Mas foi um trato difícil, ao contrário do que 
40. Cf. Lemos (1999, p. 197-198).

41. O rendado era feito em madeira e estaria "de acordo com o 'estilo chalet' que triunfava nos subúrbios de Paris nos mesmos anos $[\ldots]$ de tijolos à vista, com decorações de madeira recortada à máquina" (DEL BRENNA, 1987 , p. 32). acontecera na região cafeeira fluminense, dona de outras técnicas construtivas e que até arquitetos eruditos abrigou, trabalhando para os novos barões da Corte próxima. $\bigcirc$ neoclássico se manifestou na taipa paulista na providência de dividir frontispícios em painéis, agrupando cada um deles três ou quatro janelas ou portas-balcão. [...] nas fachadas, janelas e portas de vergas curvas de pleno cinto, isto é, bandeiras compreendendo um meio-círculo de cujo centro partiam os raios da decoração e daí, também, a possibilidade dos leques ${ }^{40}$

abertos em quarto de círculo, decorando os ângulos das peças, como bandeiras e almofadas de portas. Tais são as características do palacete do conde de Moreira Lima e de outras residências de homens ilustres de Lorena, construídas no início da época de abundância, o que corresponde, localmente, à década de 1850. "Bem ultrapassada a segunda metade do século XIX, é que surgiram as novas possibilidades construtivas e, a elas atrelado, o ecletismo" (LEMOS, 1999, p. 184).

Assim, no último quartel do século, o largo da Matriz transforma-se um pouco mais:

Datam dessa época, as reformas substanciais que transformaram a velha e senhorial residência dos Moreira Lima [...] no belo e severo edifício tão característico dessa faustosa era da aristocracia cafeeira [...]; a antiga construção do senhor João Batista de Azevedo, à praça da Matriz, na acolhedora e risonha residência do Comendador Bráulio Moreira de Castro Lima [...]; o velho sobrado do Comendador Antonio Clemente dos Santos, também no Largo da Matriz, no confortável e elegante solar dos barões de Santa Eulália, por último residência [do] Dr. Arnolfo Rodrigues de Azevedo (RODRIGUES, 1956, p. 96).

Os Moreira Lima continuam no palacete. Com o falecimento do pai, em 1879, Joaquim José Jr. assume a casa. Seu irmão Bráulio, adquire, por permuta, a casa de João Batista de Azevedo (RODRIGUES, 1956) e empreende uma reforma no edifício, provavelmente modificando-the a fachada, com a inserção das janelas em arco ogival (Figura 30). O esquema citado por Lemos (1999) continua a prevalecer: uma porta central com arco de raio pleno e janelas distribuídas simetricamente pela fachada principal. A casa era térrea mas tinha porão, uma inovação para a época, o que cria a dúvida - seria a casa toda uma construção nova, incorporando o estilo tradicional de fachada? Ou a reforma foi mais a fundo, e foi criado o porão? Infelizmente parece difícil conseguir uma resposta satisfatória, já que a casa foi demolida e existem poucos registros sobre ela.

O palacete Moreira Lima é ampliado nessa época (RODRIGUES, 1956), sendo incorporada uma varanda em sua parte posterior, cujo fechamento é feito por painéis de madeira e grandes vidraças, emolduradas por madeira trabalhada, numa espécie de rendado ${ }^{41}$. Esta varanda está apoiada sobre pilares metálicos bem esbeltos, com capitéis de ordem compósita, ou algo que a lembre (Figuras 32 e 33). A parte do telhado que cobre esse acréscimo, nova, recebe calhas com lambrequins. A parte frontal do palacete, por ser executada em taipa, continua com a mesma fachada simétrica, com painéis de três janelas ladeando a porta central, com bandeira de arco pleno. Foram retirados os dois lampiões que a guardavam (Figura 34). Convém notar que a reforma se configura como um acréscimo, pois a parte pré-existente não recebe a nova ornamentação. 


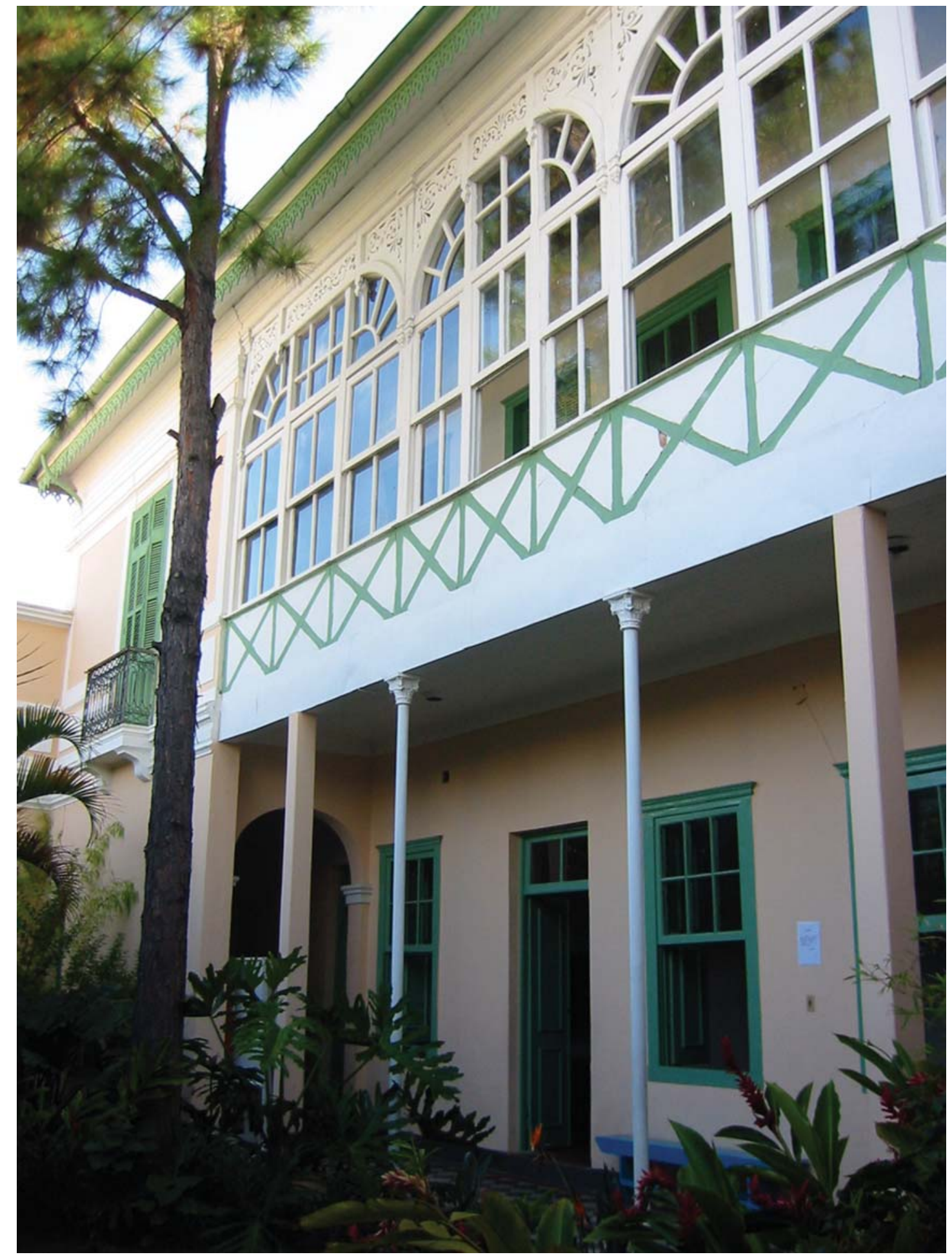

Figura 32 - Residência do conde de Moreira Lima. Acréscimo executado na reforma da década de 1880. Fotografia da autora, 2004, Lorena, SP. 


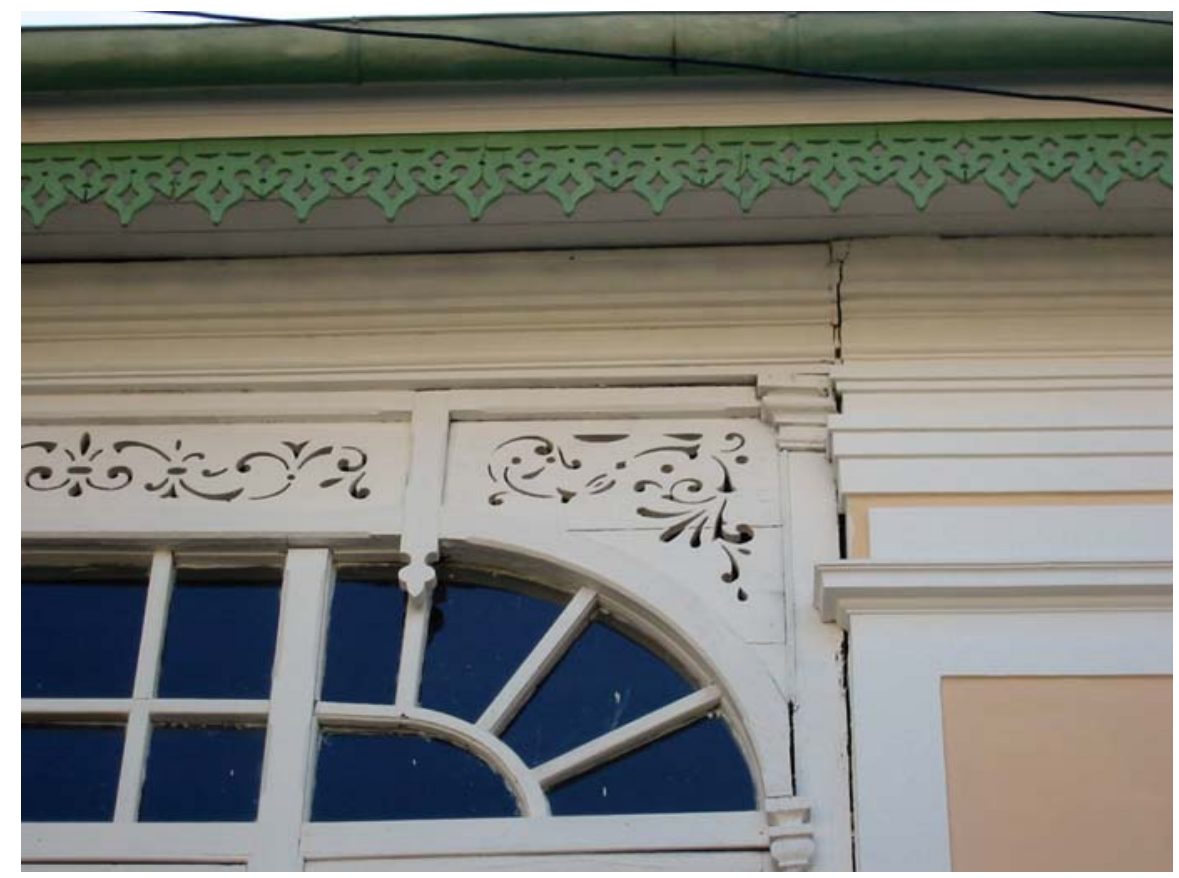

Figura 33 - Residência do conde de Moreira Lima. Detalhe onde se distingue o encontro do corpo original do edifício e do acréscimo executado na reforma da década de 1880. Fotografia da autora, 2004, Lorena, SP.

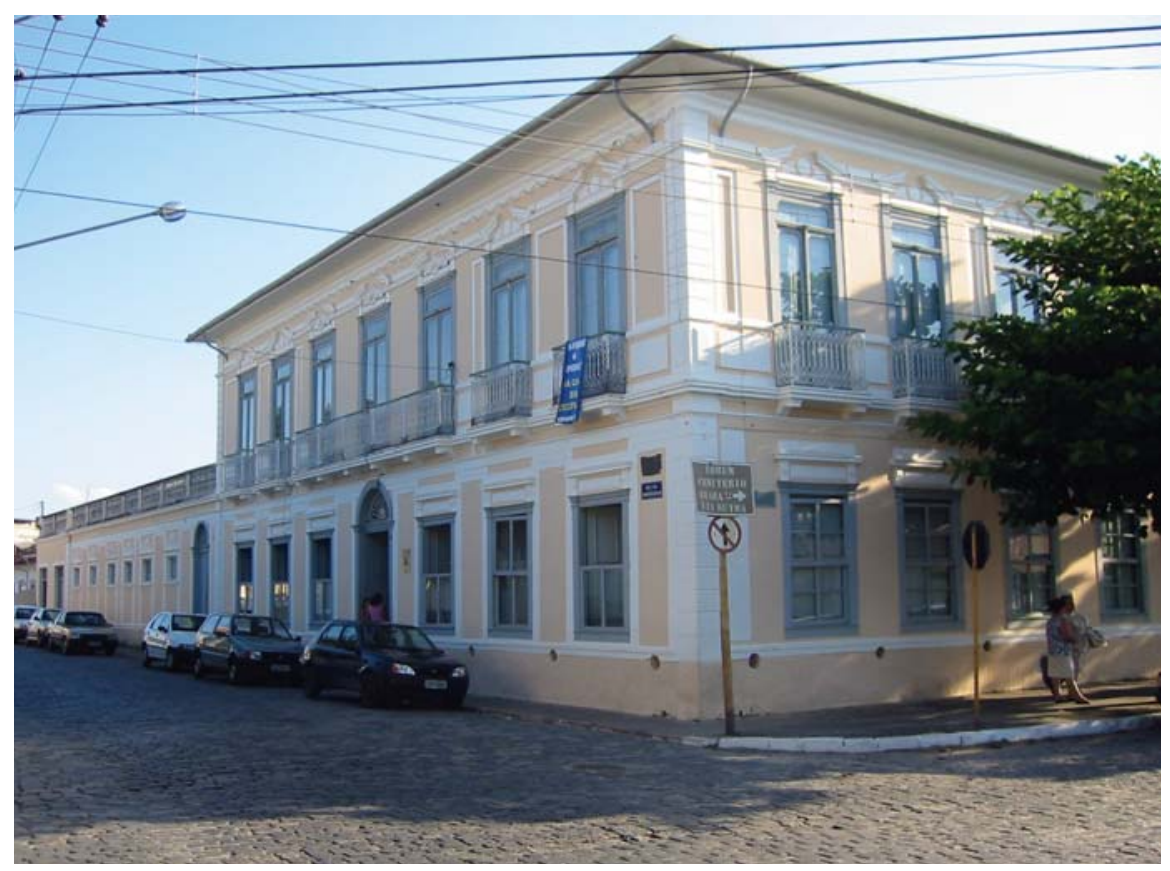

Figura 34 - Residência do conde de Moreira Lima. Aspecto exterior. Fachada para a rua da Viscondessa. Fotografia da autora, 2004, Lorena, SP. 
Não houve uma tentativa de estender o novo tratamento ao bloco original, talvez por uma questão de recursos, ou porque o conde não via inconveniente algum nisso ${ }^{42}$.

terceiro palacete também sofreu reforma, provavelmente no final da década de 1880, quando o barão de Santa Eulália contratou Ramos de Azevedo ${ }^{43}$, que à época se ocupava da construção da nova Matriz. $\bigcirc$ resultado é mais eclético que os outros dois, demonstrando aquela severidade das obras do arquiteto (Figura 35), formado em outra época e sob outra matriz, posto que, ao tempo em que estudara na Bélgica, o ecletismo europeu estava francamente consolidado ${ }^{44}$.

Quanto à lgreja Matriz, em 1886, quando da passagem do D. Pedro Il por Lorena, ainda era a mesma construção em taipa do início do século e, provavelmente, o fato se configurava como algo vergonhoso para a cidade, já então bastante transformada pelas fortunas do café. É o que se supõe a partir de uma descrição da igreja, à época, que afirmava ser o templo "grande casarão inacabado, de quatro grossíssimas paredes de taipa, já bastante arruinadas, com pesada e deselegante cobertura, sem forro, sem torres e sem soalho [...] já era velha, sem ter sido nova" (RODRIGUES, 1942, p. 70). Decidiu-se, então, pela contratação de um projeto para o novo edifício. À esta altura, Ramos de

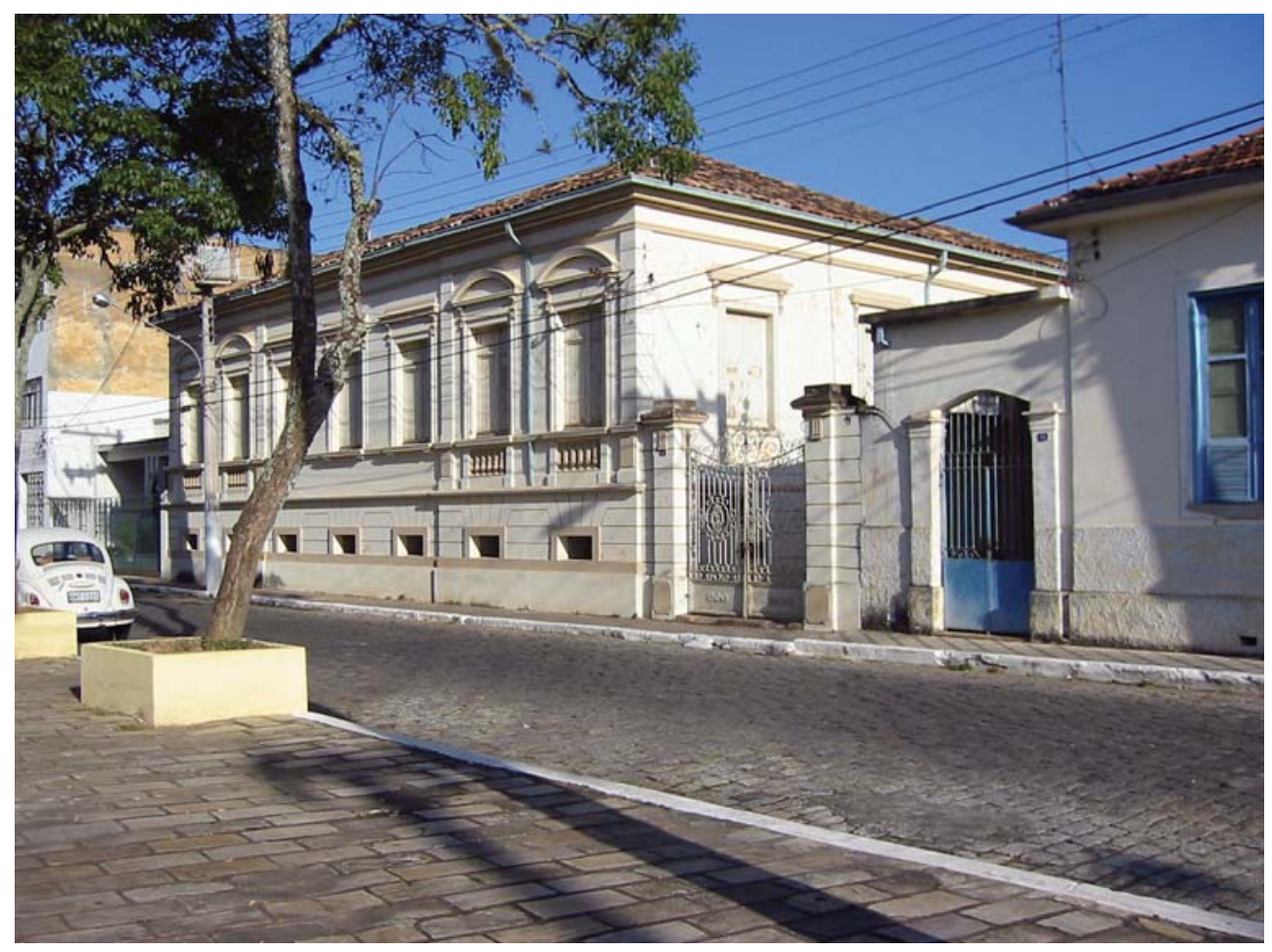

Figura 35 - Residência do barão de santa Eulália, posteriormente de Arnolfo de Azevedo. Aspecto exterior. Fachada para a praça Baroneza de Santa Eulália, antigo largo da Matriz. Autoria atribuída ao arquiteto Ramos de Azevedo. Fotografia da autora, 2004, Lorena, SP.
42. Isto é importante porque, do ponto de vista da questão histórico-patrimonial, o casarão configura-se como um exemplo pedagógico, pois estão preservados os dois principais momentos de sua construção, como se pode observar nas figuras apresentadas.

43. O imóvel é tombado no Condephaat (Processo $n$. $^{\circ} 24441 / 86$, Tomb. Res. SC41, de $18 \mathrm{dez}$. 1992, D. O. 19 dez. 1992).

44. Sobre as manifestações ecléticas em São Paulo e a formação e atuação de Ramos de Azevedo, ver em Lemos (1987; 1993). 
Azevedo já era um profissional renomado e muito requisitado. A reforma da Matriz de Campinas foi, de fato, a obra que o alçou à fama e, desde 1880, vinha desenvolvendo projetos de igrejas pelo estado de São Paulo (LEMOS, 1993). Muito provavelmente essa notoriedade foi a razão de sua escolha para o projeto da nova Matriz de Lorena. Rodrigues (1942, p. 73), em que pese o estilo um tanto rebuscado, faz uma descrição bastante fiel da obra:

Projetou o ilustre engenheiro, o novo templo lorenense em puro estilo romano, com três naves paralelas, separadas por dois renques de grupos de sólidas colunas cilíndricas, encimadas por belíssimos capitéis entrelaçados de grinaldas e flores, que sustentavam por meio de elegantes arcadas e salientes nervuras, as elevadíssimas abóbodas em arco de círculo.

Três portas lhe dariam acesso. Dezoito vastas aberturas laterais, no primeiro pavimento e vinte outras mais elevadas, todas igualmente em arco de círculo, the dariam ar e luz.

A capela-mor, em maior elevação, seria separada do corpo da igreja por artística balaustrada de mármore. Aos fundos, ampla sacristia. Uma elegante torre em forma de pirâmide quadrangular, coberta com ardósia, ladeada de quatro pequenos torreões cilíndricos, elevando-se à 60 metros de altura, dá finura e remate à fachada principal. [...] Toda a construção ocuparia uma área de 60 metros de comprido por 25 metros de largura, um pouco mais, portanto, que a velha igreja colonial anterior.

conjunto é de uma formosura austera e suave, tanto pelo seu aspecto externo, como pelo interior, ao qual os inúmeros vitrais das altas e rasgadas janelas laterais, e a excelente combinação dos mosaicos do piso emprestam um atraente encanto.

Vasto coro, duas capelas laterais, um artístico púlpito de talha de madeira, dois soberbos candelabros de prata, completam a ornamentação do belíssimo templo.

Evangelista (1978, p. 164) complementa: "todo o travejamento de aço foi importado da Bélgica; as telhas da cobertura vieram diretamente de Marselha; e os mosaicos do piso foram fabricados em Paris, mediante desenhos próprios remetidos de Lorena".

A nova Matriz é construída um pouco mais atrás em relação à implantação das igrejas que the antecedem, de modo a regularizar o largo, deixando-o retangular. Esta parece ter sido uma decisão de Ramos de Azevedo acatada pela Câmara. Há indícios de que também tenha projetado a reforma da Igreja do Rosário, quando igualmente propôs a regularização do seu largo, como atesta a declaração do Comendador Arlindo Braga, chamado a opinar a respeito:

Tendo sido chamado para me pronunciar sobre a modificação de que carece a collocação da Capella do Rosário, disse que nada podia fazer sem ouvir a Camara, e parecendo que fica mais elegante a Capella avançando um pouco para diante, indico que a Camara deixe a Cargo do Engenheiro a Collocação da Capella no lugar mais conviniente ${ }^{45}$.

Em 1884, são plantadas as palmeiras-imperiais, concomitantemente às da rua da Viscondessa. Neste largo, a plantação obedece à disposição "em renque" (Figura 36), seguindo o modelo consagrado na famosa aléia existente no Jardim Botânico do Rio de Janeiro (Figuras 3 e 6), que tanto impressiona seus visitantes. Também aqui o efeito causa impacto: as palmeiras emolduram a nova 


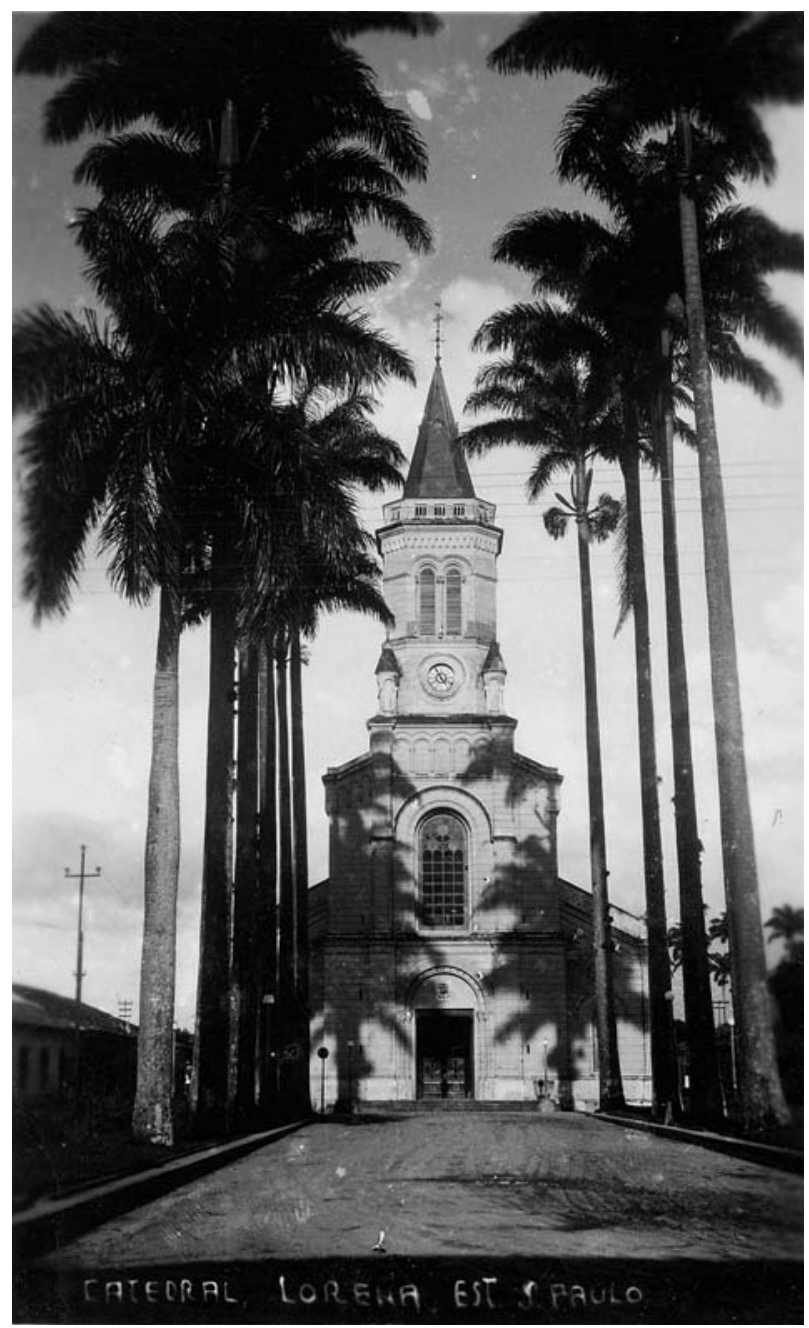

Figura 36 - Palmeiras imperiais no largo da Matriz. Fotografia, c. 1930, Lorena, SP. Acervo do Museu Paulista da Universidade de São Paulo.

Matriz, elevando todo o largo a uma escala monumental, ao dirigir o olhar do observador ao alto, aos céus.

Essa relação foi bastante explorada, sendo adotada em outros adros, sendo notáveis os exemplos da Igreja de São Francisco de Assis, em São João del Rei, e do largo do Machado, em frente à Igreja de N. Sra. da Glória, no Rio de Janeiro, que foi delimitado ainda em 1810 e cujo plantio provavelmente se deu na década de 1850, visto que em 1893-1894 Juan Gutierrez registrou as palmeiras plenamente desenvolvidas, como já mencionado. Mais recentemente, foi utilizada na reurbanização da praça da Sé, em São Paulo, demonstrando que tal configuração é extremamente expressiva e consegue repercussão mesmo no final do século XX. 
No ano de 1865, "a Camara Municipal mandou abrir uma rua direita até o portão do cemitério", obra só completada em 1878. Esta rua, continuação da rua da Viscondessa de Castro Lima, passa a chamar-se rua Direita, e a ponte que as une será chamada de ponte do Faustino, ferreiro que morava ao lado de uma de suas cabeceiras. Atualmente é a rua Conselheiro Rodrigues Alves. Em 1889, o presidente da Câmara, barão da Bocaina, solicita ao presidente da Província, Dr. Pedro Vicente de Azevedo (seu tio) uma nova ponte para o Rio Taboão (ponte do Faustino). Este, então, encomenda, na Bélgica, uma ponte metálica (Figura 26) (BARRETO, 1998, p. 1 14). A continuidade visual conseguida pelo alinhamento das duas ruas - e reforçado pela presença da ponte - cria um eixo de ligação entre o largo da Matriz e o Cemitério, que ganhará destaque na paisagem urbana lorenense a partir do plantio, em 1884, das palmeirasimperiais, resultando em impressionante composição paisagística (Figura 37), que resulta em efeito idêntico ao alcançado pela aléia de palmeiras do Jardim Botânico carioca (Figuras 3 e 6).

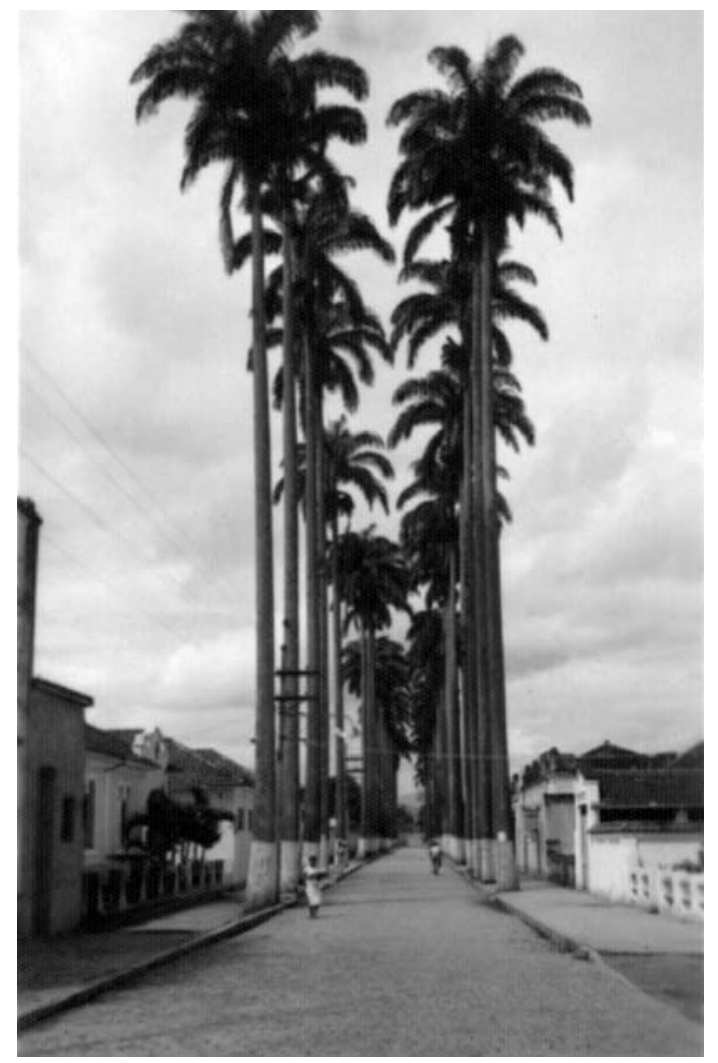

Figura 37 - Palmeiras imperiais na rua da Viscondessa, c. 1940, Lorena, SP. 5,7 × 8,7cm, fotografia. Acervo da autora, 2004. 
Dado o belíssimo resultado, o cuidado dispensado a este logradouro pela administração municipal é redobrado: ora se solicita "que se mande replantar as palmeiras da rua que vae ter ao ceminterio, substituindo por novas as que morreram", ficando algum vereador ou cidadão de destaque encarregado de encomendá-las na Corte; ora se solicita autorização para a contratação do "madeiramento necessario do engradamento das palmeiras [... ] da rua da V. de Castro Lima"46.

Introdução em São Paulo, obra de um lorenense?

Como visto, outras cidades do Vale do Paraíba também foram contempladas com palmeiras a ornamentar seus espaços públicos. A especificidade do caso de Lorena reside na sua relação com o início da utilização dessa espécie na cidade de São Paulo.

É certo que, cedo ou tarde, as palmeiras seriam utilizadas por aqui, pois, afinal, após a chegada do café, tudo se modificou, e a cidade deixa de ser um povoado acanhado, sem atrativos. A exemplo do que ocorreu no Vale do Paraíba, a transformação econômica levou à transformação da paisagem urbana, que se revelou na rápida substituição da cidade de taipa pela de alvenaria, tão bem descrita por Benedito Lima de Toledo (2004).

Na virada do século XIX para o XX há um grande empenho das diferentes administrações municipais no sentido de ordenar e sanear São Paulo. Como é sabido, uma conjunção de fatores concorreu para esse esforço, aliando, ao enriquecimento devido ao café, o acentuado crescimento populacional resultante da chegada da mão-de-obra estrangeira, dos contingentes de exescravos que vinham procurar trabalho na cidade, do incremento da indústria local, da especialização do comércio, da rapidez do transporte ferroviário e enfim, das mudanças na própria gestão da cidade, decorrentes da nova forma de governo, com a proclamação da República.

A administração republicana também necessitava de algo que simbolizasse a sua grandeza e o seu respeito para com as instituições civis. Avançando além das preocupações higienistas características da época, isso se traduziu no cuidado com os espaços públicos. Havia que enfatizar-se a riqueza trazida pelo surto cafeeiro e a austeridade do novo momento políitico.

Para isso, a fórmula que aliava uma arquitetura de contornos severos e austeros, de características classicizantes, às eloqüentes palmeiras-imperiais era perfeita, a despeito de sua origem monárquica. Tal fórmula carrega na sua essência os atributos de distinção, classe e nobreza liá expostos no início deste artigo), e poderia, portanto, vincular-se aos ideais republicanos.

Edifícios de características neoclássicas já podiam ser observados no centro ou nos arredores da capital paulista, na década de 1860, quando Militão
46. Atas da Câmara, de $1^{\circ}$. de janeiro de 1884. $22^{\text {a }}$ sessão ordinária e de 30 de outubro de $1884,18^{\mathrm{a}}$ sessão ordinária. Arquivo Municipal de Lorena. 
47. Cf. Guaraldo (2002, p. 49)

48. Idem. de Azevedo produziu sua primeira série de registros. No entanto, nesses mesmos registros não se observa nenhum exemplar de palmeira-imperial.

Mais tarde, em 1883, Carl von Koseritz, que conhecia e admirava o emprego da espécie no Rio de Janeiro, atribui a "falta" das palmeiras-imperiais em São Paulo ao clima local, menos propício para "essas plantas importadas de zonas tropicais" ${ }^{\prime 4}$. Até o presente momento, não se encontraram, em São Paulo, referências à espécie anteriores à 1905, quando o botânico Alfred Usteri cita a existência de algumas nos arredores da cidade.

Considera-se muito provável que as palmeiras tenham sido introduzidas em São Paulo quando da construção do Teatro Municipal, o que corrobora a idéia do seu vínculo com a República. Desse modo, aqui, as palmeiras-imperiais notabilizaram-se "pela sua associação com o Teatro Municipal e foram, junto com ele, o mais importante cartão postal da cidade no período" 48 (Figura 38).

Eliane Guaraldo (2002) também transcreve observação de Adolfo Pinto, datada de 1912: "[...] à rua Aurora, no 80 vêm-se dois exemplares plantados pelo sr. Pedro Vicente de Azevedo, que ostentam o mesmo garbo e completo desenvolvimento dos mais belos tipos cariocas".

De fato, em uma foto que registra a construção do viaduto Santa Efigênia, pode-se observar, à esquerda da igreja de mesmo nome, ao fundo, um exemplar de Roystonea oleracea. Espera-se que seja possível sua confirmação, já que, pelo seu posicionamento e pela data da foto - 1910 -, pode-se supor que se tratava de um dos exemplares referidos por Adolfo Pinto (Figura 39).

Por meio dessa referência é traçada a genealogia do recurso paisagístico utilizado num dos principais cartões postais paulistanos, a praça Ramos de Azevedo, pois a propriedade referida era a chácara do ex-presidente da Província de São Paulo, pertencente à elite cafeeira lorenense que promoveu o embelezamento dos logradouros da cidade vale-paraibana, na segunda metade do século XIX, inspirados nos exemplos da corte do Rio de Janeiro.

Coincidência ou não, certamente Vicente de Azevedo, quando assumiu a presidência da Província e para cá se transferiu, deve ter mandado plantar em sua propriedade na capital algumas mudas dos exemplares lorenenses, contribuindo para a inserção da espécie na paisagem paulistana do início do século XX.

Se em 1912 os exemplares citados alcançavam o seu "completo desenvolvimento", provavelmente foram plantados por volta de 1890. Como já mencionado, a administração de Pedro Vicente de Azevedo é a última do Império e ocorre nos anos de 1888-1889.

Guaraldo (2002, p. 49) continua: "A palmeira-imperial foi, assim, incluída na paisagem paulistana associada a um dos símbolos da riqueza trazida pelo café: o teatro, o lugar do espetáculo. Foi um elemento qualificador de um espaço previsto para se tornar símbolo da capital". Em Lorena, pelo menos duas décadas antes, a palmeira havia sido utilizada com o mesmo propósito: a 


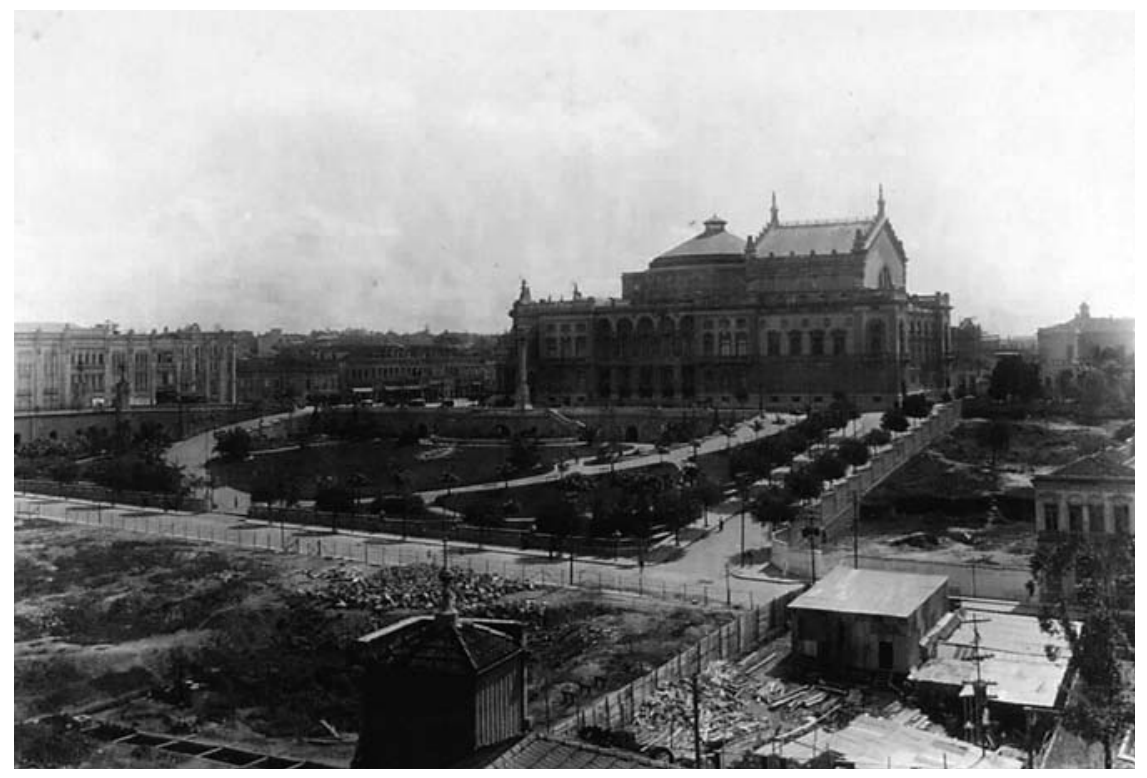

Figura 38 - Pode-se observar as palmeiras recém plantadas ao longo das alamedas que descem em direção à Rua Formosa. Teatro Municipal e São José /Construídos no antigo bairro do Chál, 1914, São Paulo. Fotografia do Álbum comparativo da cidade de São Paulo 1862-1887-1914, 1914, São Paulo, SP. $17 \times 22 \mathrm{~cm}$. Acervo da Biblioteca Municipal Mário de Andrade, São Paulo.

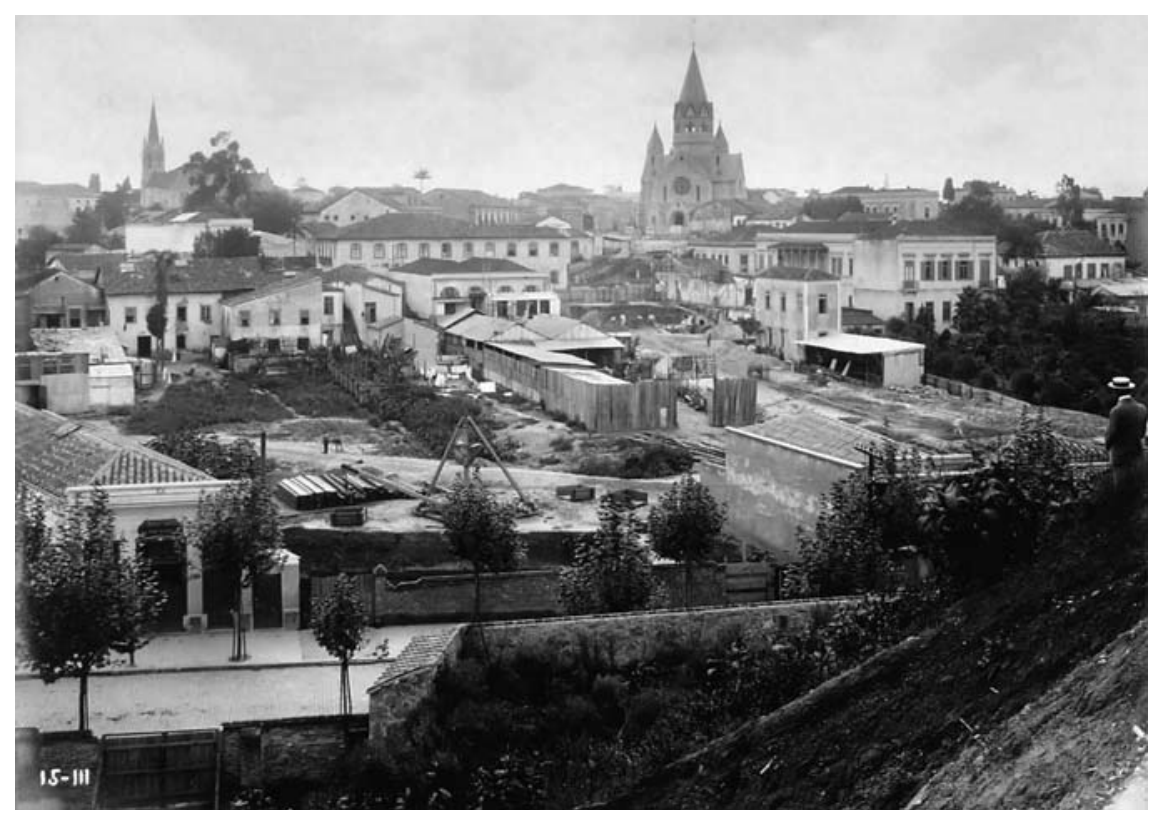

Figura 39 - Em primeiro plano, as obras do viaduto. Ao fundo, ao centro, entre as torres das igrejas, observa-se um exemplar de Roystonea oleracea. [Sem título]. Fotografia de F. Manuel, 1910, São Paulo. $17 \times 23 \mathrm{~cm}$ (MANUEL, [191 1 ]). Acervo da Biblioteca Municipal Mário de Andrade, São Paulo. 
qualificação dos logradouros públicos, para equipará-los aos novos edifícios que substituíam aqueles da tradição colonial e para qualificá-los como os espaços mais nobres da cidade, para uso da elite cafeeira.

\section{Considerações finais}

No presente texto, várias vezes foi feita alusão ao "processo de transformação" da paisagem urbana de Lorena. De fato, para o período em questão, o que houve não poderia considerar-se ter sido apenas uma evolução natural, decorrente do processo pelo qual as cidades passam ao longo do tempo, sofrendo influências das mais diversas origens. A preferência pelo termo "transformação" é devida à existência de uma ruptura do padrão urbanístico estabelecido desde os tempos coloniais, que, somada à velocidade dos processos possibilitada pela implantação da ferrovia, colocam a situação urbana lorenense em um novo patamar.

Concorrem para essa transformação, principalmente, a transferência da Corte Portuguesa para o Brasil, no início do século XIX, e a instalação da ferrovia em meados do mesmo século. O primeiro fato promoveu, no Rio de Janeiro, por decreto, a melhoria das condições de vida e da aparência da cidade, para adequá-la ao seu novo status. Tais decretos, sendo extensivos às demais cidades brasileiras, influenciaram grandemente o processo de ruptura das tradições. Promoveu, também, o ingresso de uma nova estética, trazida pelos portugueses da Corte e pelos franceses integrantes da Missão Francesa de 1816, ou por muitos dos outros que acompanharam a família real em 1808 .

A mais relevante contribuição veio através do trabalho de Grandjean de Montigny. Embora sua produção seja pequena, sua influência é enorme, ao legar à sociedade fluminense - e à elite cafeeira, por extensão - o conceito de vinculação entre Neoclassicismo e nobreza, seja de espírito, como ele acreditava, ou "de fachada", como acredita nossa elite até hoje. Nesse sentido, muito colaborou a corte ao adotar, como arquitetura oficial, o Neoclassicismo da Missão. Prevaleceu a segunda concepção, posto que o Neoclássico francês ao qual Montigny se filia e sob o qual educa seu espírito e gosto, tomava como premissa fundamental e primeira a liberdade do homem, o que o torna um paradoxo nos trópicos, ao ser adotado como estilo oficial de uma sociedade baseada na exploração da mão-de-obra escrava e dela dependente (BANDEIRA, XEXÉO, CONDURU, 20031.

Somos feitos de paradoxos. Ao encontrar-se com a civilização paulista, este "Neoclássico" - já desvirtuado em seus princípios - será desvirtuado em sua aparência, pelo empobrecimento de seu repertório, fruto da necessidade de ajustes à taipa; e à falta de técnicas à altura de seu refinamento. Somente a ferrovia, cuja velocidade encurtou as distâncias, pode possibilitar a inclusão de novos materiais e técnicas, muitos deles exigindo a importação de mão-de-obra 
específica, como ocorreu no episódio do ajardinamento do largo Imperial e no caso do Engenho Central de Lorena, que, com sua maquinaria importada da França, impunha a contratação de técnicos especializados para a sua manutenção.

As mudanças se processaram, primeiramente, no âmbito privado e, em seguida, nos espaços públicos. Surge, então, o elemento que proporciona a articulação entre ambos: a palmeira-imperial. Definidas por Ribeiyrolles (1980) como os "guardas imóveis" do Jardim Botânico carioca, guardam também o acesso ao porto do Paraíba, o passeio das famílias no largo Imperial e, solenes, a última viagem em direção ao cemitério. Emolduram a nova Matriz - "um templo, em suma, de puro estilo romano, todo ele incombustível, solidamente construído, em condições de atravessar séculos...", com teria dito o próprio Ramos de Azevedo (RODRIGUES, 1956, p. 102) - e o solo sagrado de seu adro, ao mesmo tempo em que evocam, ao se apresentarem dispostas em renque, aquelas sensações que os visionários neoclássicos como Boulée exploravam e buscavam em seus projetos grandiosos e de perspectivas infinitas. $O$ Neoclassicismo, nas ruas de Lorena, expressa-se por meio das suas palmeiras.

Procurou-se demonstrar, também, que essa configuração paisagísticasurgida e consolidada de fato durante o Segundo Império, com sua carga simbólica de vinculação ao poder e à nobreza - foi apropriada para ser utilizada nos espaços de representação da República. Isto só se tornou possível porque ambos os momentos, Império e República, guardavam fatores em comum: primeiro, a sua sustentação política foi proporcionada pela mesma elite agrária e, em segundo, nos dois momentos existe um projeto de Nação muito semelhante, que procura uma identidade brasileira própria e a sua inserção no cenário internacional.

Assim ocorreu em Lorena e em outras cidades do Vale. Assim o será em um dos espaços mais nobres da capital paulista - a esplanada do Teatro Municipal, sempre evocando outra planta transformadora: o café. 


\section{REFERÊNCIAS}

AGASSIZ, L. Viagem ao Brasil: 1865-1866. São Paulo: Edusp, 1975.

ÁLBUM comparativo da cidade de São Paulo 1862-1887-1914. São Paulo: Casa Duprat, 1914. v. 1 .

AZEVEDO,M.D. O Rio de Janeiro.v.II.ed.anot. Elysio de Oliveira Belchior. Rio de Janeiro:Brasiliana, s.d.

BANDEIRA, J.; XEXÉO, P.M.C.; CONDURU, R. A Missão Francesa. Rio de Janeiro: Sextante, 2003.

BARRETO,A. M. Lorena: aspectos históricos da Câmara Municipal. Lorena, SP: Stiliano, 1998.

BIBLIOTECA NACIONAL. Correspondência passiva de Coelho Neto. In: Anais da Biblioteca Nacional. Rio de Janeiro, v. 78, p. 186-187, 1963. Disponível em <http://www.bn.br/fbn/bibsem fronteiras/principal.htm>.Acesso em 26 set. 2006.

BRUNO, E. S. (Org.). São Paulo: terra e povo. Porto Alegre: Globo, 1967.

CANABRAVA,A. P. Esboço da história econômica de São Paulo. In: BRUNO, E. S. (Org.). São Paulo: terra e povo. Porto Alegre: Globo, 1967.p. 32-37.

CESAR, F. Resenha histórica de Lorena. Lorena: Estabelecimento Graphico São José, 1928.

D'ELBOUX, R.M.M.Vale do Paraíba:fusão de saberes e técnicas. Registros, Mar del Plata (Argentina), v. 1, n. 2, p. 219-235, dez. 2004.

DEAN, W.A Botânica e a política imperial: introdução e adaptação de plantas no Brasil Colonial e Imperial. Conferência realizada no Instituto de Estudos Avançados da Universidade de São Paulo, 21 jun. 1989. In: Estudos Avançados, São Paulo, IEA/USP, junho 2001, 96 p. (Coleção Documentos, Série Ciências Humanas-História, n. 17).

. A ferro e a fogo: a história da devastação da Mata Atlântica. São Paulo: Cia. das Letras, 1996.

DEL BRENNA, G. R. Ecletismo no Rio de Janeiro (séc. XIX-XX). In: FABRIS,A. (org.). Ecletismo na arquitetura brasileira. São Paulo: Nobel; Edusp, 1987. p. 29-67.

EVANGELISTA, J. G. Lorena no século XIX. São Paulo: Governo do Estado de São Paulo, 1978 (Paulística, 7).

Retalbos históricos de Lorena. Lorena: Sociedade Amigos da Cultura de Lorena, 2001 (Lorenense, 5).

FRIDMAN, F. Donos do Rio em nome do rei: uma história fundiária da cidade do Rio de Janeiro. Rio de Janeiro:J. Zahar; Garamond, 1999. 
GERODETTI, J. E., CORNEJO, C. Lembranças de São Paulo: o interior paulista nos cartões-postais e álbuns de lembraças. São Paulo: Solaris, 2003.

GRAF,A. B. Tropica: color cyclopedia of exotic plants and trees. East Rutherford, NJ: Rohers, 1986. $1152 \mathrm{p}$.

GUARALDO, E. Repertório e identidade: espaços públicos em São Paulo, 1890-1930. 2002. 191 p. Tese (Doutorado em Arquitetura e Urbanismo) - Faculdade de Arquitetura e Urbanismo, Universidade de São Paulo, São Paulo, 2003.

HAUSSMANN, B. Mémoires. Paris: Éditions du Seuil, 2000.

HUGUENEY,J.Haussmann et les jardins publics. In:RÉAU,L.(org.).L'oeuvre du Baron Haussmann, Préfet de la Seine (1853-1870). Paris: Presses Universitaires de France, 1954.p.91-123.

IPJBRJ.A palma mater. In: Homepage do Instituto de Pesquisas Jardim Botânico do Rio de Janeiro. Disponível em http://www.jbrj.gov.br/historic/palmater.htm .Acesso em 28 jun. 2005.

LAGO, B. C. D. Augusto Stabl: obra completa em Pernambuco e Rio de Janeiro. Rio de Janeiro: Contra Capa; Capivara, 2001 (Visões do Brasil, 3)

LEMOS, C.A. C. Casa paulista: história das moradias anteriores ao ecletismo trazido pelo café. São Paulo: Edusp, 1999

Ecletismo em São Paulo. In: FABRIS,A. O. (org.). Ecletismo na arquitetura brasileira. São Paulo: Nobel; Edusp, 1987. p. 69-103.

. O álbum de Afonso: a reforma de São Paulo. São Paulo: Pinacoteca do Estado, 2001.

Ramos de Azevedo e seu escritório. São Paulo: Pini, 1993.

LORENZI, H. et al. Palmeiras no Brasil: nativas e exóticas. Nova Odessa (SP): Plantarum, 1996, $303 \mathrm{p}$.

MAIA,T., HOLANDA, S. B. D. Vale do Paraíba, velbas fazendas. São Paulo: Nacional, 1975.

MANUEL, F. Álbum da construcção do viaducto Sta. Ephigenia. 1910-1911. São Paulo: F. Manuel, [1911]

MORSE, R. Formação bistórica de São Paulo. São Paulo: Difusão Européia do Livro, 1970

MOTTA SOBRINHO,A. A civilização do café (1820-1920). São Paulo: Brasiliense, 1967.

MOURA, C. E. M. D. O Visconde de Guaratinguetá: um fazendeiro de café no Vale do Paraíba. Ed. rev. e ampl. São Paulo: Studio Nobel, 2002.

O BRASIL de Marc Ferrez. São Paulo: Instituto Moreira Salles, 2005. 
REIS, P. P. D. O caminbo novo da Piedade no nordeste da capitania de São Paulo: apontamentos para o estudo do "Caminho Novo da Freguesia da N. Sra. da Piedade à Fazenda Santa Cruz dos padres jesuítas” (1725-1822). São Paulo: Conselho Estadual de Cultura, [1971].

RIBEYROLLES, C. Brasil pitoresco: história, descrições, viagens, colonização, instituições. São Paulo: Itatiaia; Edusp, 1980.

RODRIGUES,A. D. G. Gens lorenensis: do serão de Guaypacaré à formosa cidade de Lorena (16461946). Lorena: [s.e.], 1956.

O Conde de Moreira Lima. São Paulo: Instituto Genealógico Brasileiro, 1942 (Biblioteca Genealógica Brasileira, 2).

SAINT-HILAIRE,A. D. Segunda viagem do Rio de Janeiro a Minas Gerais e a São Paulo, 1822. Belo Horizonte: Itatiaia; São Paulo: Edusp, 1974 (Reconquista do Brasil, 11).

SARTHOU, C. Relíquias da cidade do Rio de Janeiro. Rio de Janeiro:Atheneu, 1965, 153 p.

TAUNAY,Alphonse D'Escragnolle. A Missão Artística de 1816. Brasília: Editora da Universidade de Brasília, 1983 (Temas brasileiros, 34).

TOLEDO, Benedito Lima de. São Paulo: três cidades em um século. São Paulo: Cosac \& Naïy; Duas Cidades, 2004

ZALUAR,A. E. Peregrinação pela província de São Paulo (1860-1861). São Paulo: Itatiaia; Edusp, 1975 (Reconquista do Brasil, 23).

Artigo apresentado em 6/2006. Aprovado em 12/2006. 